\title{
Debris Flows from Tributaries of the Colorado River, Grand Canyon National Park, Arizona
}

U.S. GEOLOGICAL SURVEY PROFESSIONAL PAPER 1492

Prepared in cooperation with the U.S. Bureau of Reclamation

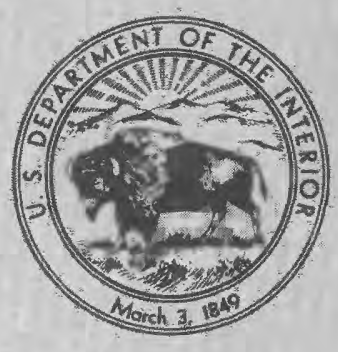




\section{AVAILABILITY OF BOOKS AND MAPS OF THE U.S. GEOLOGICAL SURVEY}

Instructions on ordering publications of the U.S. Geological Survey, along with prices of the last offerings, are given in the current-year issues of the monthly catalog "New Publications of the U.S. Geological Survey." Prices of available U.S. Geological Survey publications released prior to the current year are listed in the most recent annual "Price and Availability List." Publications that are listed in various U.S. Geological Survey catalogs (see back inside cover) but not listed in the most recent annual "Price and Availability List" are no longer available.

Prices of reports released to the open files are given in the listing "U.S. Geological Survey Open-File Reports," updated monthly, which is for sale in microfiche from the U.S. Geological Survey, Books and Open-File Reports Section, Federal Center, Box 25425 , Denver, CO 80225 . Reports released through the NTIS may be obtained by writing to the National Technical Information Service, U.S. Department of Commerce, Springfield, VA 22161; please include NTIS report number with inquiry.

Order U.S. Geological Survey publications by mail or over the counter from the offices given below.

\section{BY MAIL}

\section{Books}

Professional Papers, Bulletins, Water-Supply Papers, Techniques of Water-Resources Investigations, Circulars, publications of general interest (such as leaflets, pamphlets, booklets), single copies of Earthquakes \& Volcanoes, Preliminary Determination of Epicenters, and some miscellaneous reports, including some of the foregoing series that have gone out of print at the Superintendent of Documents, are obtainable by mail from

\section{U.S. Geological Survey, Books and Open-File Reports Federal Center, Box 25425 Denver, CO 80225}

Subscriptions to periodicals (Earthquakes \& Volcanoes and Preliminary Determination of Epicenters) can be obtained ONLY from the

\section{Superintendent of Documents Government Printing Ornce Washington, D.C. 20402}

(Check or money order must be payable to Superintendent of Documents.)

\section{Maps}

For maps, address mail orders to

\section{U.S. Geological Survey, Map Distribution \\ Federal Center, Box 25286 \\ Denver, CO 80225}

Residents of Alaska may order maps from

\author{
Alaska Distribution Section, U.S. Geological Survey, \\ New Federal Building - Box 12 \\ 101 Twelfth Ave., Fairbanks, AK 99701
}

\section{OVER THE COUNTER}

\section{Books}

Books of the U.S. Geological Survey are available over the counter at the following Geological Survey Public Inquiries Offices, all of which are authorized agents of the Superintendent of Documents:

- WASHINGTON, D.C.--Main Interior Bldg., 2600 corridor, 18th and C Sts., NW.

- DENVER, Colorado--Federal Bldg., Rm. 169, 1961 Stout St.

- LOS ANGELES, Californla--Federal Bldg., Rm. 7638, 300 N. Los Angeles St.

- MENLO PARK, Callfornia--Bldg. 3 (Stop 533), Rm. 3128. 345 Middlefield Rd.

- RESTON, Virginia--503 National Center, Rm. 1C402, 12201 Sunrise Valley Dr.

- SALT LAKE CITY, Utah--Federal Bldg., Rm. 8105, 125 South State St.

- SAN FRANCISCO, Callfornia--Customhouse, Rm. 504, 555 Battery St.

- SPOKANE, Washington--U.S. Courthouse, Rm. 678, West 920 Riverside Ave.

- ANCHORAGE, Alaska--Rm. 101, 4230 University Dr.

- ANCHORAGE, Alaska--Federal Bldg, Rm. E-146, 701 C St.

\section{Maps}

Maps may be purchased over the counter at the U.S. Geological Survey offices where books are sold (all addresses in above list) and at the following Geological Survey offices:

- ROLLA, Missouri--1400 Independence Rd.

- DENVER, Colorado--Map Distribution, Bldg. 810, Federal Center

- FAIRBANKS, Alaska--New Federal Bldg., 101 Twelfth Ave. 


\section{Debris Flows from Tributaries of the Colorado River, Grand Canyon National Park, Arizona}

By ROBERT H. WEBB, PATRICK T. PRINGLE, and GLENN R. RINK

U.S. GEOLOGICAL SURVEY PROFESSIONAL PAPER 1492

Prepared in cooperation with the U.S. Bureau of Reclamation

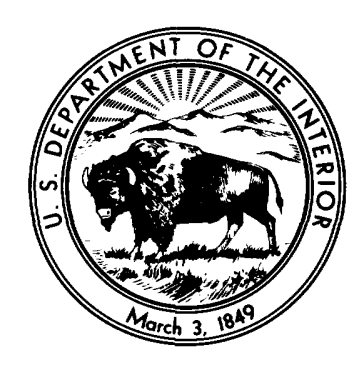

United States GOVERnMENT PRINTING OfFice, WAShington : 1989 


\section{DEPARTMENT OF THE INTERIOR}

MANUEL LUJAN, JR., Secretary

\section{U.S. GEOLOGICAL SURVEY}

Dallas L. Peck, Director

Any use of trade, product, or firm names in this publication is for descriptive purposes only and does not imply endorsement by the U.S. Government

\section{Library of Congress Cataloging-in-Publication Data}

Webb, Robert $\mathbf{H}$.

Debris flows from tributaries of the Colorado River, Grand Canyon National Park, Arizona / by Robert H.

Webb, Patrick T. Pringle, and Glenn R. Rink.

p. cm. - (U.S. Geological Survey professional paper ; 1492)

"Prepared in cooperation with the U.S. Bureau of Reclamation."

Bibliography: p.

Supt. of Docs. no.: I 19.16:1492

1. Mass-wasting-Arizona-Grand Canyon. I. Pringle, Patrick T. II. Rink, Glenn R. III. United States. Bureau of Reclamation. IV. Title. V. Series.

QE598.5.U6W43 1989

For sale by the Books and Open-File Reports Section, U.S. Geological Survey

Federal Center, Box 25425, Denver, CO 80225 


\section{CONTENTS}

\begin{tabular}{|c|c|c|c|}
\hline & Page & & Page \\
\hline Abstract- - - - - - - - - & 1 & Debris flows in three tributaries of the Colorado River- & \\
\hline troduction $--\ldots-\ldots-\ldots--\ldots-\ldots-\ldots-\ldots-\ldots$ & 1 & Continued & \\
\hline Acknowledgments $-\ldots-\ldots---\ldots-\ldots--\ldots-\ldots$ & 2 & Monument Creek drainage-Continued & \\
\hline tent of debris flows in the Grand Canyon $\ldots \ldots$ & 3 & Discharge calculations $-\ldots-\ldots-\ldots-\ldots$ & 12 \\
\hline draulics of debris flows $-\ldots-\ldots-\ldots \ldots$ & 3 & Sediment volume $\ldots \ldots \ldots-\ldots \ldots \ldots$ & 13 \\
\hline bris flows in three tributaries of the Colorado River - . - & 5 & Crystal Creek drainage $\ldots-\ldots \ldots$ & \\
\hline Methods $-\ldots---_{-}$ & 5 & Stratigraphy- $--\ldots-\cdots------_{-}$ & \\
\hline Lava-Chuar Creek drainage $\ldots \ldots \ldots \ldots$ & 5 & Longitudinal variation in the 1966 debris-flow & \\
\hline Stratigraphy- $--\cdots-\ldots-\ldots-\ldots$ & 6 & deposits $------------\cdots------$ & \\
\hline Longitudinal variation in the 1966 debris-flow & & Discharge calculations $-------\cdots$ & \\
\hline$-\ldots-\ldots-\ldots-\ldots-\ldots-\ldots$ & 8 & Similarities and contrasts among the drainages ----- & \\
\hline Discharge calculation $-\ldots-\ldots-\ldots-\ldots-\ldots$ & 9 & Fluvial events in other drainages $\ldots$ & \\
\hline Monument Creek drainage $\ldots-\ldots-\ldots,-\ldots-\ldots$ & 9 & 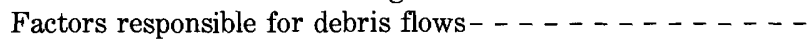 & \\
\hline Stratigraphy- ------------------- & 10 & Hydrologic effects of debris flows on the Colorado River - - - & \\
\hline Longitudinal variation in the 1984 debris-flow & & Summary ---------------------- & \\
\hline deposits $-----\cdots-----\cdots-\cdots-\cdots$ & 11 & References cited ------------------- & \\
\hline
\end{tabular}

\section{ILLUSTRATIONS}

FIgURe 1. Map showing areas of study in Grand Canyon National Park, Arizona-

2. Map showing the Lava-Chuar Creek drainage at mile 65.5 on the Colorado River $-\ldots \ldots$

3. Photographs showing Lava Creek at the confluence with Chuar Creek, 3.8 miles upstream from the Colorado River -- -

4. Graph showing stratigraphy of debris-flow deposits in the Lava-Chuar Creek drainage $\ldots$

5. Photographs showing Lava Creek, 0.2 mile upstream from the confluence with Chuar Creek

6. Graph showing particle-size distributions of the debris flow of 1966 in the Lava-Chuar Creek drainage - . . - . -

7. Map showing the Monument Creek drainage at mile 93.5 on the Colorado River

8. Photographs showing the mouth of Monument Creek $\ldots \ldots \ldots \ldots$

9. Graph showing stratigraphy of debris-flow deposits in the Monument Creek drainage - _ _ _

10. Graph showing particle-size distributions of the debris flow of 1984 in the Monument Creek drainage- $-\ldots$

11. Plan map and longitudinal profile for indirect-discharge site B in Monument Creek, 0.5 mile upstream from the Colorado

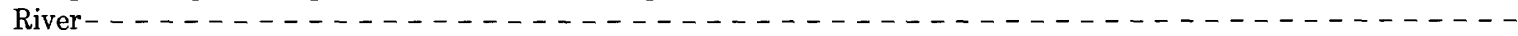

12. Hypothetical hydrograph of the debris flow of 1984 in Monument Creek as suggested by stratigraphic evidence - - - -

13. Map showing the Crystal Creek drainage at mile 98.2 on the Colorado River $-\ldots$

14. Graph showing stratigraphy of debris-flow deposits in the Crystal Creek drainage

15. Photographs showing Dragon Creek, 6.2 miles upstream from the Colorado River $\ldots \ldots \ldots$

16. Graph showing particle-size distributions of the debris flow of 1966 in the Crystal Creek drainage $\ldots$

17. Photographs showing Crystal Rapid at the mouth of Crystal Creek $\ldots \ldots$

18. Longitudinal profiles for indirect-discharge sites in the Crystal Creek drainage - $-\ldots$

19. Graphs showing relation of characteristics of rapids and the contributing drainage area of the tributaries _ - . - - -

20. Schematic diagram showing geomorphic features of a typical rapid controlled by debris flows on the Colorado River - - -

\section{TABLES}

TABLE 1. Selected tributaries of the Colorado River, Grand Canyon National Park

2. Indirect-discharge calculation for the debris flow of 1966 on Lava-Chuar Creek, 0.2 mile upstream from the Colorado

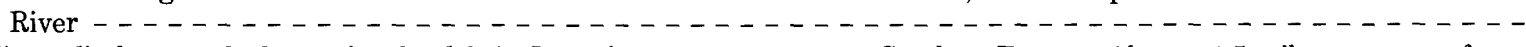

3. Indirect-discharge calculation for the debris flow of 1984 on Monument Creek at Tapeats Alcove, 1.5 miles upstream from

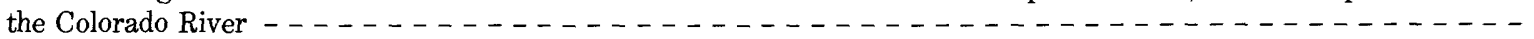


TABLE 4. Indirect-discharge calculations for the debris flow of 1984 on Monument Creek at site B, 0.5 mile upstream from the

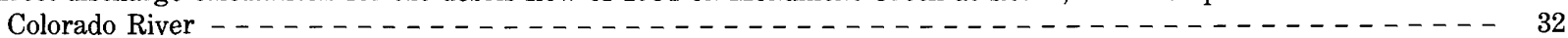

5. Indirect-discharge calculation for the debris flow of 1984 on Monument Creek at site C, 0.3 mile upstream from the

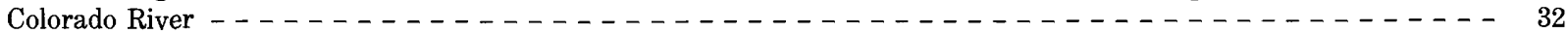

6. Four scenarios of deposition on the Monument Creek debris fan used to calculate volumes of sediment deposited during

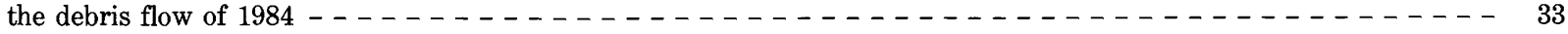

7. Indirect-discharge calculation for the debris flow of 1966 on Dragon Creek at site E, 5.0 miles upstream from the

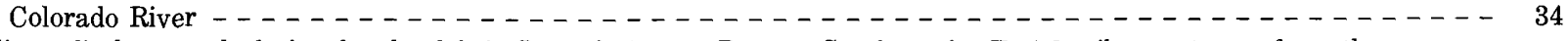

8. Indirect-discharge calculation for the debris flow of 1966 on Dragon Creek at site F, 4.8 miles upstream from the

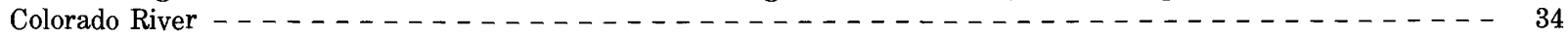

9. Indirect-discharge calculations for the debris flow of 1966 on Crystal Creek at site G, 0.9 mile upstream from the

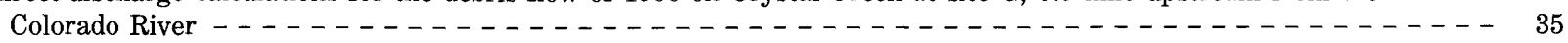

10. Comparison of discharges calculated at all superelevation sites by the cross-sectional area at the highest superelevation marks and an average of the upstream and (or) downstream cross-sectional areas _ _ _ _ _ _ _ _ _ _ _ _ 35

11. Historic flow events or channel changes in tributaries of the Colorado River in Grand Canyon National Park - - - - - - 36

12. Relation between difficulty rating for rapids and drainage area of the contributing tributaries for 67 rapids on the

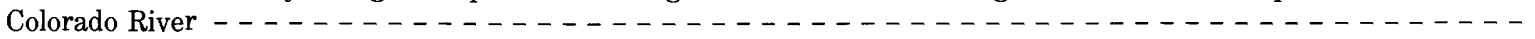

\section{METRIC CONVERSION FACTORS}

For readers who prefer to use the metric (International System) units, the conversion factors for the inch-pound units used in this report are listed below:

\begin{tabular}{rcl}
\hline \multicolumn{1}{r}{ Multiply inch-pound unit } & By & \multicolumn{1}{c}{ To obtain metric unit } \\
\hline inch (in.) & 25.4 & millimeter $(\mathrm{mm})$ \\
foot (ft) & 0.3048 & meter $(\mathrm{m})$ \\
square foot $\left(\mathrm{ft}^{2}\right)$ & 0.09294 & square meter $\left(\mathrm{m}^{2}\right)$ \\
cubic foot ( $\left.\mathrm{ft}^{3}\right)$ & 0.2832 & cubic meter $\left(\mathrm{m}^{3}\right)$ \\
foot per second $(\mathrm{ft} / \mathrm{s})$ & 0.3048 & meter per second $(\mathrm{m} / \mathrm{s})$ \\
mile $(\mathrm{mi})$ & 0.02832 & cubic meter per second $\left(\mathrm{m}^{3} / \mathrm{s}\right)$ \\
cubic foot per second $\left(\mathrm{ft}^{3} / \mathrm{s}\right)$ & 1.609 & kilometer $(\mathrm{km})$ \\
square mile $\left(\mathrm{mi}^{2}\right)$ & 2.59 & square kilometer $\left(\mathrm{km}^{2}\right)$ \\
acre-foot per year (acre-ft/yr) & 1,233 & cubic meter per year $\left(\mathrm{m}^{3} / \mathrm{yr}\right)$ \\
pound (lb) & 453.6 & gram $(\mathrm{g})$ \\
ton & 0.9072 & megagram $(\mathrm{Mg})$ \\
\hline
\end{tabular}

Sea level: In this report "sea level" refers to the National Geodetic Vertical Datum of 1929 (NGVD of 1929)-A geodetic datum derived from a general adjustment of the first-order level nets of both the United States and Canada, formerly called "Mean Sea Level of 1929." 


\title{
DEBRIS FLOWS FROM TRIBUTARIES OF THE COLORADO RIVER, GRAND CANYON NATIONAL PARK, ARIZONA
}

\author{
By Robert H. Webi, Patrigk T. Pringle, and Glenn R. Rink
}

\begin{abstract}
A reconnaissance of 36 tributaries of the Colorado River indicates that debris flows are a major process by which sediment is transported to the Colorado River in Grand Canyon National Park. Debris flows are slurries of sediment and water that have a water content of less than about 40 percent by volume. Debris flows occur frequently in arid and semiarid regions. Slope failures commonly trigger debris flows, which can originate from any rock formation in the Grand Canyon. The largest and most frequent flows originate from the Permian Hermit Shale, the underlying Esplanade Sandstone of the Supai Group, and other formations of the Permian and Pennsylvanian Supai Group. Debris flows also occur in the Cambrian Muav Limestone and underlying Bright Angel Shale and the Quaternary basalts in the western Grand Canyon.

Debris-flow frequency and magnitude were studied in detail in the Lava-Chuar Creek drainage at Colorado River mile 65.5; in the Monument Creek drainage at mile 93.5; and in the Crystal Creek drainage at mile 98.2. Debris flows have reached the Colorado River on an average of once every 20 to 30 years in the Lava-Chuar Creek drainage since about 1916. Two debris flows have reached the Colorado River in the last 25 years in Monument Creek. The Crystal Creek drainage has had an average of one debris flow reaching the Colorado River every 50 years, although the debris flow of 1966 has been the only flow that reached the Colorado River since 1900 . Debris flows may actually reach the Colorado River more frequently in these drainages because evidence for all debris flows may not have been preserved in the channel-margin stratigraphy.

Discharges were estimated for the peak flow of three debris flows that reached the Colorado River. The debris flow of 1966 in the Lava-Chuar Creek drainage had an estimated discharge of 4,000 cubic feet per second. The debris flow of 1984 in the Monument Creek drainage had a discharge estimated between 3,600 and 4,200 cubic feet per second. The debris flow of 1966 in the Crystal Creek drainage had a discharge estimated between 9,200 and 14,000 cubic feet per second. Determination of the effective cross-sectional area was a problem in all calculations involving superelevations on bends because areas near superelevation marks were 1.5 to 3.5 times larger than areas of upstream or downstream cross sections.

Debris flows in the Grand Canyon generally are composed of 10 to 40 percent sand by weight and may represent a significant source of beach-building sand along the Colorado River. The particle-size distributions are very poorly sorted and the largest transported boulders were in the Crystal Creek drainage. The large boulders transported into the Colorado River by debris flows create or change hydraulic controls (rapids); these controls appear to be governed by the magnitude and frequency of tributary-flow events and the history of discharges on the Colorado River. Reworking of debris fans by the Colorado River creates debris bars that constrain the size of eddy systems and forms secondary rapids and riffles below tributary mouths.
\end{abstract}

\section{INTRODUCTION}

Sediment transported from small drainages is a potentially significant contribution to the sediment budget of the Colorado River in Grand Canyon National Park, Arizona (fig. 1). Little is known about the annual sediment yields from these drainages; however, many researchers have noted the efficacy of tributaries for moving large boulders into the Colorado River, which locally form rapids (Dolan and others, 1978; Graf, 1979; Hamblin and Rigby, 1968; Kieffer, 1985; Leopold, 1969). Indeed, large rapids may be the most obvious geomorphic and hydrologic manifestation of sediment transport from small drainages in Grand Canyon National Park.

Estimation of sediment yields from ungaged Colorado River tributaries in Grand Canyon National Park is difficult and uncertainties in cited figures are large. Howard and Dolan (1981) estimated an average annual sediment yield for these tributaries of 2,100 acre-ft/yr by use of a sediment-mass balance for the Colorado River. However, they estimated the change in storage of sediment in the bed of the Colorado River by using an average channel width and by assuming that sand covered an average of 75 percent of the channel bed. Laursen and others (1976) estimated an average annual sediment yield of 0.7 acre$\mathrm{ft} / \mathrm{yr}$ of "beach-building sand" on the basis of differences in suspended-sediment transport between the gaging stations at the Colorado River at Lees Ferry and the Colorado River at Grand Canyon. Mass-balance estimates of sediment yields contain considerable uncertainty because the change in bed storage is unknown.

Sediment yields from these tributaries also could be estimated using methodology presented by the Pacific Southwest Inter-Agency Committee (1968). This methodology was developed from rangeland monitoring efforts on terrain with low to moderate topographic relief. Sediment yields are determined from a quasi-analytical procedure that is based on geology, soils, climate, drainage-basin characteristics, and channel stability. Use of the methodology requires the tacit assumption that sediment is transported by Newtonian streamflow. The 
method produces a sediment yield per unit area, which implies that drainage-basin area is the most important factor influencing sediment yield.

In the study of the tributaries of the Colorado River, the key to estimating sediment yield is an understanding of the sediment-transport process. A previous flood report (Cooley and others, 1977) and recent mapping of alluvial deposits in tributary canyons during this project indicate that debris flow is the dominant process for sediment transport in small drainages in Grand Canyon National Park. Debris flows are common in arid and semiarid drainages (Blackwelder, 1928); however, their importance in supplying sediment to the Colorado River has not been previously recognized.

The purpose of this report is to document the extent of debris flows in Grand Canyon National Park and the occurrence and magnitude of debris flows in three Colorado River tributaries. The effects of these events on the mainstem-channel morphology are necessary in understanding sediment transport and hydraulic controls in the Colorado River. This study was funded in cooperation with the U.S. Bureau of Reclamation as part of a larger study entitled "Glen Canyon Environmental Studies."

\section{ACKNOWLEDGMENTS}

The authors thank J.T. Brown, M.D. Daggett III, S.L. Reneau, and V.A. Yocum for their help with the fieldwork and companionship during the river trip. R.M. Turner of the U.S. Geological Survey rephotographed historic scenes in Monument, Crystal, and Dragon Creeks. R.C. Euler of the National Park Service shared his Grand Canyon archaeological experiences and provided photographs of the Crystal Creek and Lava-Chuar Creek drainages. Hal G. Stevens, formerly of the U.S. Geological Survey, generously provided his matched photograph of Hillers' view of the mouth of Monument Creek. V.A.S. McCord and T.P. Harlan of the Laboratory of Tree-Ring Research, University of Arizona, examined tree-ring specimens that exhibited damage from debris flows. J.D. Rogers, Rogers/Pacific Consultants, Lafayette, California, provided published and unpublished manuscripts on debris flows and geology of the Grand Canyon. Bryan Brown, Kim Crumbo, Larry Stevens, and Mike Yard, Colorado River boatmen, shared their experiences with Grand Canyon navigation and changes in rapids. Mike Walker and Mike Yard provided eyewitness accounts of

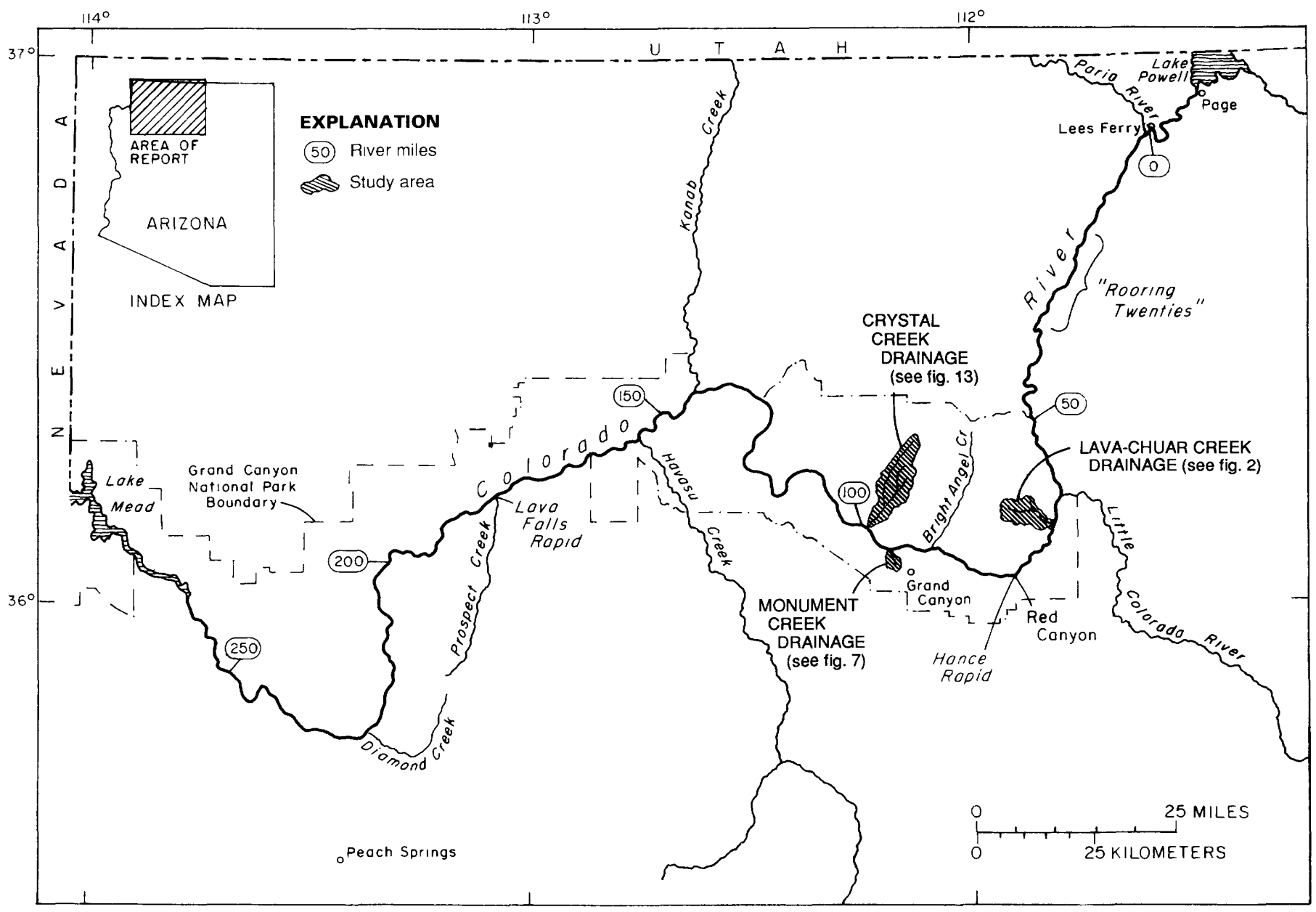

Figure 1.-Areas of study in Grand Canyon National Park, Arizona. 
Grand Canyon debris flows. S.W. Kieffer and T.C. Pierson of the U.S. Geological Survey and S.L. Reneau of the University of California at Berkeley critically reviewed the manuscript. Jack C. Schmidt and Julia B. Graf, U.S. Geological Survey, Tucson, discussed aspects of the research and provided a different perspective on the hydrologic effects of debris flows on the Colorado River. We especially thank Curt Green, Bob Marley, and Tom Wise of the U.S. Geological Survey for being excellent field assistants and skeptics; we hope to share more field seasons with them.

\section{EXTENT OF DEBRIS FLOWS IN THE GRAND CANYON}

Debris flows are flowing water-based slurries of poorly sorted clay- to boulder-sized particles (Costa, 1984). Terms sometimes intended to be synonymous include mudflows, debris slides, debris torrents, mud slides, or lahars (volcanic debris flows). Debris flows occur in many different environments ranging from deserts (Johnson and Rodine, 1984) to montane forests (Gallino and Pierson, 1985) and offshore continental shelf slopes (Piper and others, 1985). Debris flows tend to form their own channels between levees that are parallel to the flow direction when unconfined by an existing channel. These levees are composed of boulders which commonly appear to be floating in a matrix of gravel, sand, and clay (Costa, 1984; Johnson and Rodine, 1984) and have a distinctly different morphology from typical alluvial deposits.

Many classification schemes have been proposed for coarse-grained sediment flows based on water content during transport (Beverage and Culbertson, 1964), characteristics of the resultant alluvial deposits (Smith, 1986; Pierson and Scott, 1985), or on assumed rheological models of flow dynamics (Postma, 1986). Debris flows typically have 15 to 40 percent volumetric water content compared with 40 to 80 percent for hyperconcentrated flows and 80 to 100 percent water for streamflows (Beverage and Culbertson, 1964). The main distinction in this study is the difference between debris-flow deposits and hyperconcentrated-flow deposits (Beverage and Culbertson, 1964; Scott, in press) because debris flows can transform into hyperconcentrated flow with distance from the source area (Pierson and Scott, 1985). This distinction is important because hyperconcentrated flows are quasi-Newtonian fluids and debris flows are not.

Debris-flow deposits are differentiated from hyperconcentrated-flow deposits on the basis of characteristic particle sorting, sedimentary structures, and inferred rheological properties. Readers are referred to detailed descriptions of each type of deposit in Smith (1986) and Scott (1985). Debris-flow deposits are characterized by lack of sedimentary structures, poor sorting of particles, matrix support of cobbles and boulders, and, in some cases, inverse fine to coarse grading. Hyperconcentratedflow deposits are also poorly sorted but exhibit clast support of large particles, have weak sedimentary structures, and cannot transport the extremely large boulders moved during debris flows. Streamflow deposits are well-sorted, have imbricated clasts and well-developed sedimentary structures, and are easily distinguished from debris-flow deposits.

We studied 36 tributaries of the Colorado River, and all had characteristic debris-flow deposits (table 1). Most tributaries have only debris-flow deposits and inconspicuous hyperconcentrated-flow deposits; a few tributaries in the western Grand Canyon (such as Havasu Creek, fig. 1) have both well-sorted streamflow deposits and debrisflow deposits. Twenty-one of the 36 tributaries have evidence of debris flows within the last 25 years, including fresh boulder levees and matrix-supported deposits. This sampling of the nearly 310 ungaged tributaries of the Colorado River between Lees Ferry and Diamond Creek (fig. 1) suggests that debris flows are a major process of sediment transport from small drainages to the Colorado River in Grand Canyon National Park.

\section{HYDRAULICS OF DEBRIS FLOWS}

Debris flows have properties important both to hydraulic calculations and preservation of evidence for past events. Debris flows are non-Newtonian, or cohesive fluids that commonly move essentially as a plug in high-velocity laminar flow (Enos, 1977; Johnson and Rodine, 1984). Viscosities for debris flows may be several orders of magnitude higher than the viscosity of water (Costa, 1984). Particle interlocking in the dense fluid results in internal friction and shear strength. As a result, debris flows have a finite thickness called the critical thickness at a velocity of zero. Turbulence is dampened in the moving fluid (Enos, 1977), which results in laminar flows that have significantly higher Reynolds numbers than in streamflows (Costa, 1984; Johnson and Rodine, 1984). These properties enable debris flows to be extremely erosive in channels and yet to flow around brittle plants on nearby channel margins. As a result, evidence for past debris flows was found entrained in the spines of live cacti, whereas 2-ft diameter cottonwoods were sheared off on nearby flood plains in Colorado River tributaries that have had recent debris flows.

One facet of debris-flow hydraulics facilitates the creation and maintenance of Colorado River rapids. Debris flows can transport large boulders long distances from source areas. This property may result from cohesive strength, which is largely a function of clay content; from buoyancy forces on large particles that increase because of lessened density differences with the surrounding debris-flow matrix; from greater shear stress and high drag forces at the base of the debris flow; from slightly 
positive pore-water pressures in debris flows; or from a combination of these factors (Costa, 1984; Johnson and Rodine, 1984; Pierson, 1981). Regardless of the process, the characteristic boulder fans at the mouths of Colorado River tributaries (Hamblin and Rigby, 1968; Howard and Dolan, 1981; Stevens, 1983) result from debris-flow deposition and subsequent reworking of the deposits to remove the matrix.

The hydraulics of debris flows are unusual compared with streamflow because of the high sediment concentrations and interactions among particles. Most indirect velocity calculations for streamflow use Manning's equation

$$
v=\frac{1.49}{n} \cdot R^{0.67} \cdot S^{0.5}
$$

where $v=$ mean velocity, $R=$ hydraulic radius, $S=$ the friction slope, and $n=$ the roughness coefficient. Equation 1 cannot be applied to debris flows because the roughness coefficient cannot be accurately estimated (Antonious Laenen, U.S. Geological Survey, written commun., 1986; Laenen and others, 1987) and because debris flows are not Newtonian fluids. Application of the Manning equation using the slope-area method (Chow, 1959) resulted in a substantial overestimation of discharge for debris flows in Colorado (Costa and Jarrett, 1981).

Debris flows have been modeled as a Bingham substance (Johnson and Rodine, 1984) and as a viscoplastic fluid (Chen, 1985). Use of either method for calculating velocities of debris flows requires estimation of coefficients related to shear strength or flow behavior. These coefficients have large ranges and considerable error is involved in their estimation. For example, A. Laenen (written commun., 1986) has shown that Chen's (1985) flow-behavior index, back-calculated from measured debris flows, varied by an order of magnitude during a single event and varied by more than three orders of magnitude when different events were compared. Such variation indicates that calculation of velocities from postevent evidence using these methods would involve considerable potential error.

For this study, we used simplified hydraulic formulae to calculate flow velocities for debris flows (Pierson, 1985). Evidence for the elevation of the velocity head (Chow, 1959) usually is found where an obstacle is oriented perpendicular to the flow direction. In the Grand Canyon, flow impinging on vertical bedrock walls generally will leave runup evidence in sites that are protected from weathering. The mean velocity, $v$, is calculated by equating the kinetic energy of the flow to the potential energy of the runup by

$$
v=\left(2 \cdot g \cdot \Delta h_{r}\right)^{0.5}
$$

where $g=$ gravitational acceleration $(32.2 \mathrm{ft} / \mathrm{s})$ and $\Delta h_{r}=$ the difference between the runup and unobstructed flowsurface elevations. An energy-correction coefficient normally applied to open-channel hydraulics is assumed to be 1 because of plug flow. Energy losses are assumed to be negligible.

Superelevation occurs on bends as a result of centrifugal-acceleration forces. The water-surface profile on the inside and outside of a bend drops and rises, respectively, to form an elevation difference $\Delta h_{s}$ (Pierson, 1985, fig. 4). Assuming that all streamlines follow the same radius of curvature (assumed to be the centerline radius of curvature, $R_{c}$ ), fully developed plug flow, and negligible energy losses, the mean velocity around a bend is calculated from

$$
v=\left(g \cdot R_{c} \cdot \Delta h_{s} / k \cdot W\right)^{0.5}
$$

where $W=$ the effective channel width and $k=$ a correction factor (Hungr and others, 1984). Hungr and others (1984) suggest that $k=2.5$ to correct for reported overestimation of debris-flow velocities; however, we used $k=1$ because equations 2 and 3 then provided internally consistent velocities. More sophisticated equations for calculating velocity from superelevation (Apmann, 1973) probably are not warranted for debris flows in irregular natural channels.

Application of equations 2 and 3 to debris flows has been widely used but the results have been uncertain. Pierson (1985) found that use of these formulae resulted in computed velocities averaging 15 percent lower than actual velocities on the basis of measured travel times. Hence, use of equations 2 and 3 may result in a slightly conservative estimate of velocity. The amount of error introduced by the other assumptions is unknown but probably is high.

The resultant discharge $Q$ is estimated from

$$
Q=A \cdot v
$$

where $A=$ cross-sectional area. Use of equation 4 requires the assumption that all of the fluid passing through crosssectional area $A$ is moving at a mean velocity of $v$. This assumption may not be valid because of ineffective flow areas on bends (see section "Similarities and Contrasts Among the Drainages"). Froude numbers were calculated from

$$
\mathrm{F}=\frac{v^{2}}{g \cdot D}
$$

where $D$ is the hydraulic depth $(A / W)$. In Newtonian streamflow, Froude numbers greater than 1 indicate supercritical flow while Froude numbers less than 1 in- 
dicate subcritical flow. It is uncertain whether Froude numbers have the same significance when applied to debris flows. Enos (1977) found no consistent quantitative measure to define different energy regimes in debris flows.

\section{DEBRIS FLOWS IN THREE TRIBUTARIES OF THE COLORADO RIVER}

The magnitude and frequency of debris flows were evaluated in three Colorado River tributaries (fig. 1). Lava-Chuar Creek drainage at mile 65.5 on the Colorado River had a debris flow during a storm on December 3-6, 1966 (Cooley and others, 1977). Monument Creek at mile 93.5 had a debris flow during a summer thunderstorm on July 25, 1984 (Potochnik and Reynolds, 1986). The Crystal Creek drainage at mile 98.2 also had a debris flow during the storm in December 1966 (Cooley and others, 1977). Peak discharges for these three events were estimated, and the channel-margin stratigraphy was analyzed for other past events. The fieldwork for this project was completed in March and April 1986.

\section{METHODS}

The stratigraphy in the drainages that were investigated was described to provide a chronology of debris flows. Correlations among deposits were made on the basis of characteristic lithologies, sedimentary structures, color, stratigraphic position, and degree of particle-size sorting. Organic samples contemporaneous with past debris flows were collected for radiocarbon analysis by accelerator-dating techniques (Taylor and others, 1984) or conventional gas-proportional counting. Accelerator dating was used for some samples because they were too small to be analyzed by conventional gas-proportional counting. Analyses of scarred trees (Hupp, 1984), historical photographs, aerial photographs, and damage to historic structures provided additional dating of events.

The deposits from the debris flow of 1966 were identified from photographs in Cooley and others (1977) and by observation of damaged trees and recent deposits in the Lava-Chuar Creek and Crystal Creek drainages. Deposits from the 1984 debris flow in Monument Creek were fresh and easily identified. Deposits were traced longitudinally using stratigraphic and sedimentologic characteristics. High-water marks were preserved as lines under small rock overhangs; as mud deposits in and under cacti, trees, and shrubs; as distinct levees or overbank deposits; and as distinct mud lines deposited over older material on hillslopes. The red color of the debris-flow deposits in Crystal Creek, for example, was vivid when emplaced against the dark brown soils on hillslopes or as a mud line against the reddish brown Cambrian Tapeats Sandstone.
We collected 5- to 10-pound samples of debris-flow matrix (diameter less than $16 \mathrm{~mm}$ ) for reconstitution of water content during the event (Cooley and others, 1977; Gallino and Pierson, 1985; Johnson and Rodine, 1984). Water was gradually added to the samples until the mixture had observable cohesion and matrix support of 16-millimeter particles. This method is relatively precise because small changes in the water content cause large changes in cohesion (Costa, 1984). In the samples, a 1 to 2 percent by weight ( 2 to 4 percent by volume) range in water contents that created a debris-flow type of fluid was measured. Additional uncertainty occurs from changes in the particle size of deposits during post-event dewatering (Gallino and Pierson, 1985) or by lateral or longitudinal facies changes. This uncertainty was minimized by selective sampling of intact debris-flow matrix in protected sites and near sites where discharges were estimated. Samples were sieved to obtain particle-size distributions by weight percent, and point counts of particle diameters were made in the field. The two methods yield a numerically equivalent particle-size distribution (Kellerhals and Bray, 1971; Pierson, 1980).

\section{LAVA-GHUAR GREEK DRAINAGE}

The Lava-Chuar Creek drainage, $21.3 \mathrm{mi}^{2}$ in area, heads on the Walhalla Plateau in the eastern Grand Canyon (figs. 1, 2). The bedrock geology of this drainage consists of an entire Paleozoic section of rocks (McKee, 1969) that form cliffs in the headwaters, Precambrian Galeros Formation that underlies more than 75 percent of the drainage in the open Chuar Valley, and Precambrian Dox Sandstone that is exposed in the first mile above the confluence with the Colorado River (Huntoon and others, 1986). The topographic relief in the drainage basin is 5,300 $\mathrm{ft}$ and the average channel slope is 0.1 .

A debris flow occurred in the drainage as a result of intense rainfall in December 1966. An estimated 12 to 14 in. of precipitation fell during the 5-day storm (Cooley and others, 1977). A debris flow began with multiple slope failures in the Permian Hermit Shale and Esplanade Sandstone in Natchi Canyon (fig. 2) and continued $6.5 \mathrm{mi}$ to the Colorado River. Additional slope failures from the same formations in Lava Canyon (fig. 2) may have contributed sediments to the debris flow. Cooley and others (1977) report considerable damage throughout the canyon from the debris flow but do not report a discharge for the event. R.C. Euler (National Park Service, oral commun., 1986) visited archaeological sites in the canyon before and after the debris flow, and his photographs illustrate the extent of channel changes (fig. $3 A, B$ ). It is not certain to what extent Lava Canyon Rapid at the mouth of the Lava-Chuar Creek drainage on the Colorado River was affected by this debris flow. 


\section{STRATIGRAPHY}

In addition to the debris flow of 1966, at least two debris flows have occurred historically in the Lava-Chuar Creek drainage. Exposures of debris-flow sediments deposited before and after 1966 were present at intervals along the entire length of the Lava-Chuar Creek drainage (fig. 4). Replication of photographs presented in Cooley and others (1977) indicates that a debris flow occurred after 1966 (fig. 5). A comparison of aerial photographs indicated that this flow occurred between 1973 and 1984. The peak stage for the post-1966 debris flow was lower than the 1966 debris flow near the confluence of Lava and Chuar Creeks (site $\mathrm{C}$, fig. 2) but was about equivalent near the mouth. The relation of discharge to stage is unknown because the post-1966 debris flow or other unknown streamflows locally entrenched the bed of Lava Creek by 2 to $5 \mathrm{ft}$ over a
10- to 15 -foot width from the level of 1966 (fig. 5). In the 1-mile reach above the Colorado River, the presence of substantial material from the Dox and Galeros Formations in post-1966 debris-flow deposits indicates significant local sediment contributions from small side drainages, scour of channel deposits, and (or) slope failures.

An older and substantially larger debris flow occurred in Lava Creek in historic times before 1966. Cooley and others (1977) report the presence of driftwood deposited before 1966 near the confluence with Chuar Creek; similar driftwood mixed with boulders in a debris-flow levee was found at higher elevations above the channel than reported by Cooley and others (1977). The older debris flow overtopped an abandoned grinding mill at MacDonald Spring (site D, fig. 2) that was probably constructed as part of a distilling operation between 1890 and 1915 (Harvey Butchart, retired professor, Northern

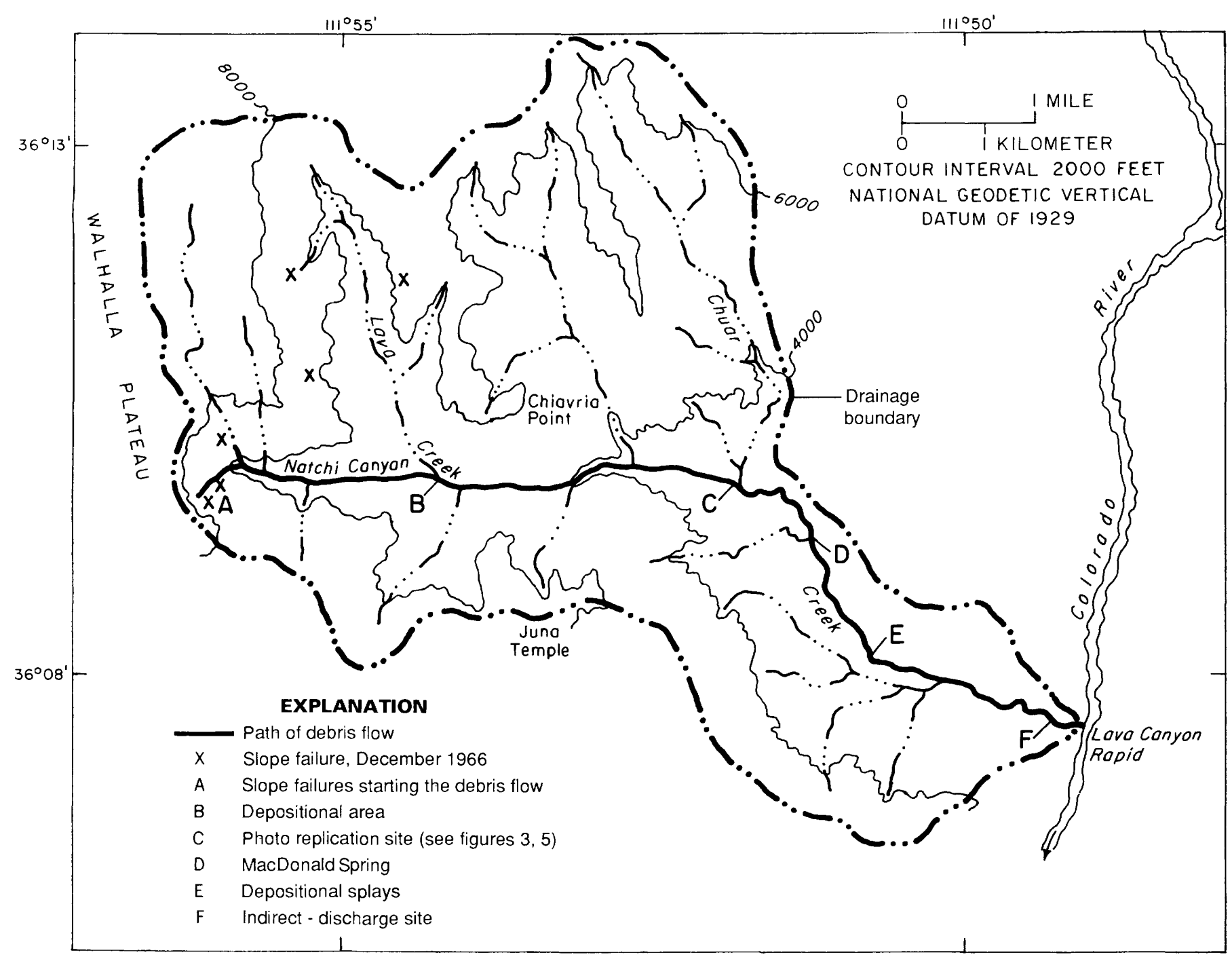

FIgURE 2.-The Lava-Chuar Creek drainage at mile 65.5 on the Colorado River. See figure 1 for location. 
Arizona University, oral commun., 1986). The debris flow deposited distinctive sediments in the mill and left the trunk of an uprooted cottonwood tree on the nearby
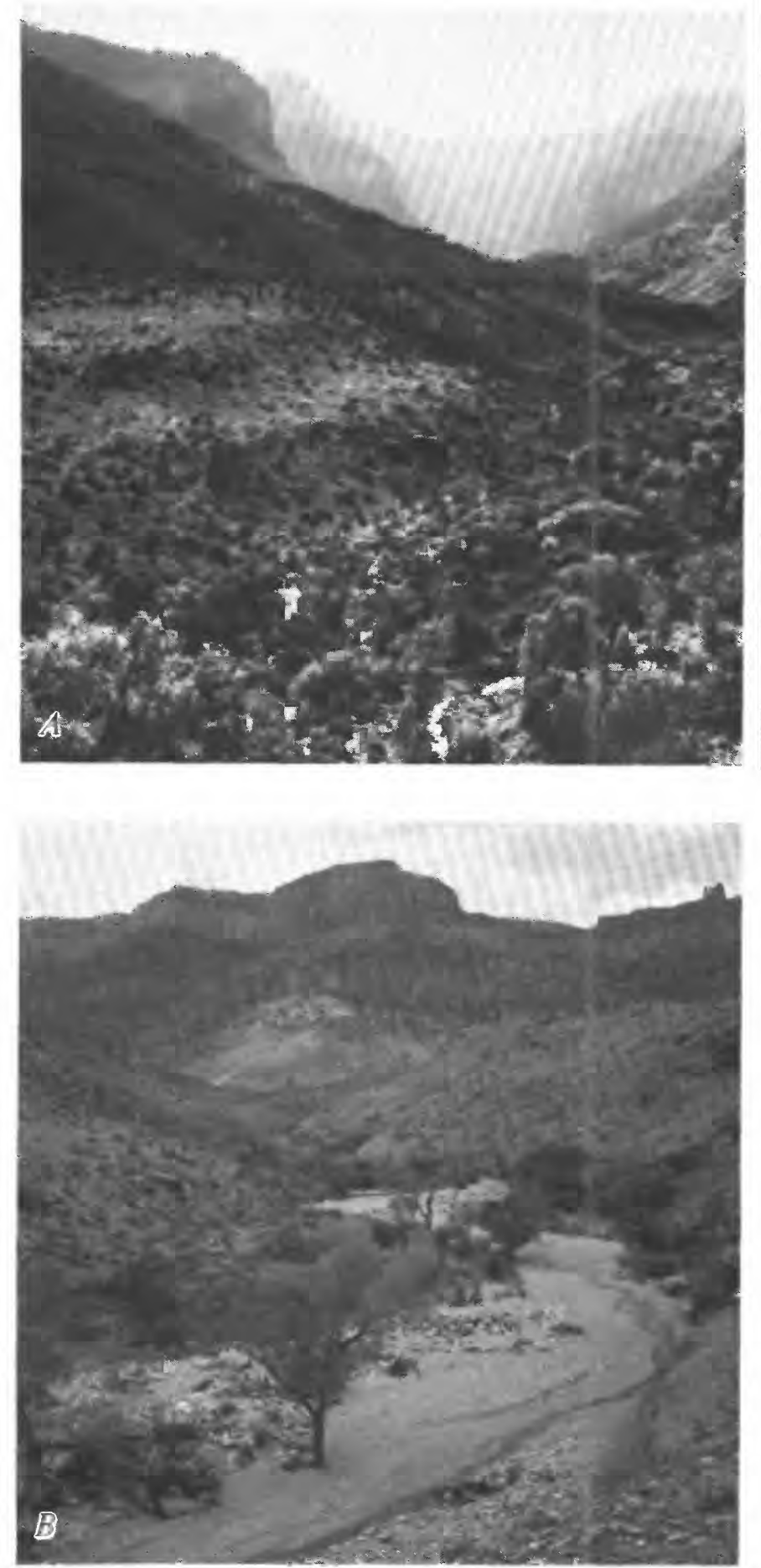

Figure 3.-Lava Creek at the confluence with Chuar Creek, 3.8 miles upstream from the Colorado River. View $B$ (May 1967) is slightly different from $A$ (May 1966) and shows significant channel alteration following the 1966 debris flow. View $C$ (March 1986) matches $B$ and terrace. This flow also lapped onto a 10 -foot-high terrace near the confluence with the Colorado River and nearly damaged an historic housepad. The pre-1966 debris flow deposited sediments twice as thick as the preserved sediments of the debris flow of 1966 in some places along the channel (fig. 4).

Evidence for at least five prehistoric debris flows is preserved in prominent terraces along Lava Creek (fig. 4). Hyperconcentrated-flow deposits and possible channelfill facies of additional debris flows also were found. Sediments are preserved as much as $12 \mathrm{ft}$ above the channel bed of 1986 near the Colorado River and as much as $20 \mathrm{ft}$ above the channel bed in the narrow reaches near the headwaters. Driftwood lodged in a debris-flow deposit (symbol Z; fig. 4) $12 \mathrm{ft}$ above the channel bed of $1986 \mathrm{had}$ a radiocarbon age of $250 \pm 80 \mathrm{yr}$ B.P. (years before present) (sample number A-4543). This deposit could not be traced downstream from site B (fig. 2). Radiocarbon dating of entrained wood in debris-flow deposits $\mathrm{X}$ and $\mathrm{W}$ (fig. 4) indicate maximum ages of $625 \pm 65$ (AA-1787) and $1,460 \pm 60$ (AA-1788) yr B.P. for these debris flows, respectively. The younger of these events $(\mathrm{X})$ had a hyperconcentrated-flow facies associated with the deposit. On the basis of deposit thickness and height above the channel, the debris flows $\mathrm{W}, \mathrm{X}$, and $\mathrm{Y}$ had little attenuation in stage in the 3-mile reach between sites $\mathrm{E}$ and $\mathrm{F}$ (fig. 2) and reached the Colorado River.

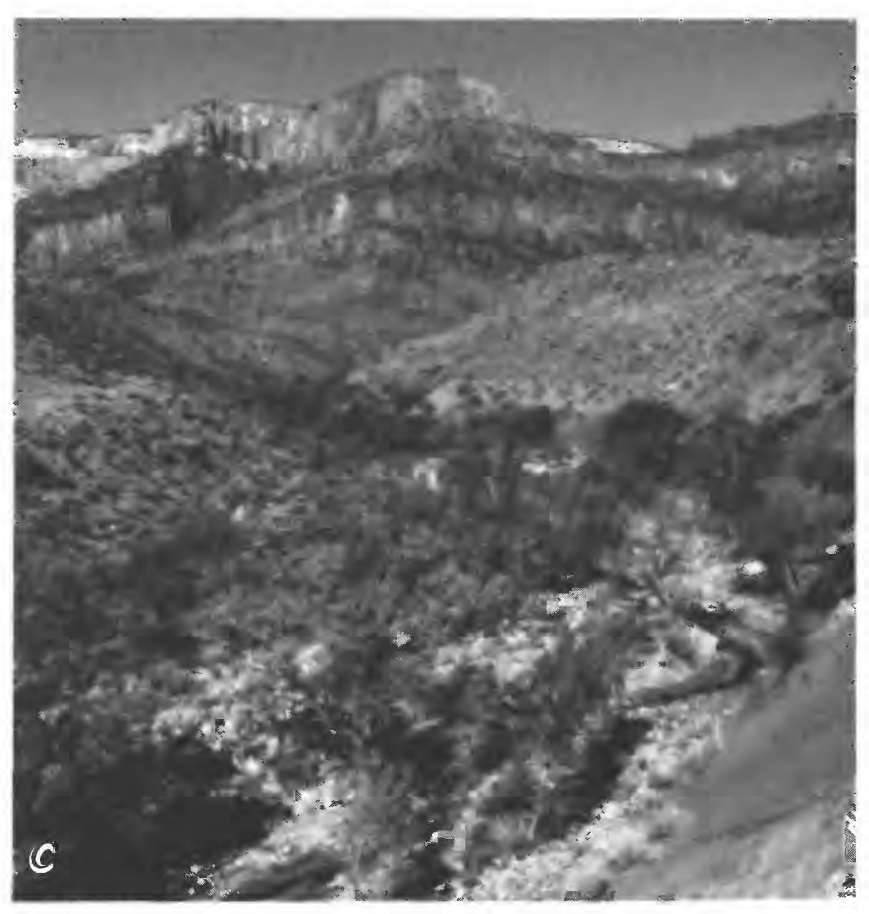

shows revegetation and entrenchment of the channel after the 1966 and subsequent debris flows. Photograph by R.C. Euler (National Park Service). See site C, figure 2, for location. 
The stratigraphy in the Lava-Chuar Creek drainage suggests an average interval of about 20 to 30 years between debris flows during the last 80 years, depending on the age used for the mill at MacDonald Spring. On the basis of radiocarbon-dated debris-flow deposits in terraces, the Lava-Chuar Creek drainage has had a minimum of one debris flow that reached the Colorado River every 190 years during the last 1,500 years. Debris flows may actually reach the Colorado River more frequently because small prehistoric debris flows, such as debris flow $\mathrm{Z}$, may not have overtopped the terraces to leave depositional evidence.

\section{LONGITUDINAL VARIATION IN THE 1966 DEBRIS-FLOW DEPOSITS}

Sedimentologic characteristics of the debris flow of 1966 show little significant longitudinal variation in cohesiveness. As noted by Cooley and others (1977), the flow remained a debris flow the entire length of the drainage. The flow sustained or locally increased its volume by incorporation of bed material, talus, and exposed sedimentary rocks of the Galeros and Dox Formations. Abundant vesicles preserved in the debris-flow matrix at many sites indicate significant air entrapment in the flow or frothy,

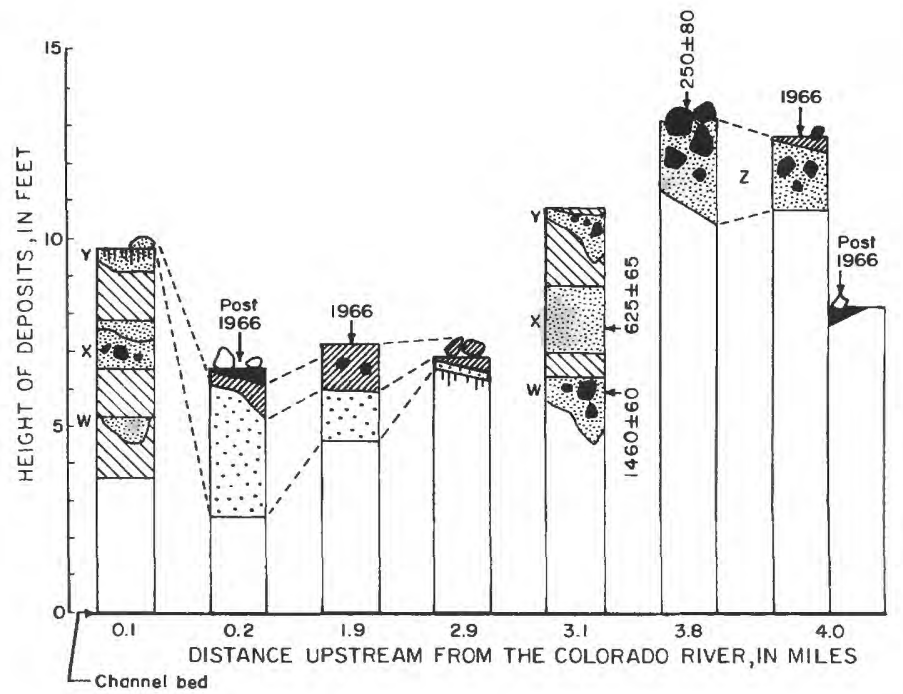

EXPLANATION

\begin{tabular}{|c|c|}
\hline $250 \pm 80$ & Radiocarbon age, in years before present \\
\hline & Post - 1966 debris-flow deposit \\
\hline & 1966 debris-flow deposit \\
\hline$\because \because \because$ & Historic debris-flow deposit \\
\hline W. & Prehistoric debris-flow deposit \\
\hline एग & Soil or incipient soil \\
\hline & Stratigraphy hidden or not present \\
\hline DIV & Talus, hillslope debris, or Colorado River deposit \\
\hline - & Boulder \\
\hline $6 x_{7}$ & Labels for correlative debirs-flow deposits \\
\hline
\end{tabular}

FIGURE 4.-Stratigraphy of debris-flow deposits in the Lava-Chuar Creek drainage. turbulent conditions at the flow margins. Mudcoats preserved on bedrock walls and indurated calcic deposits also demonstrate that the flow retained its cohesive properties throughout the length of the drainage.

Upon debouching from Natchi Canyon, the debris flow deposited an extensive field of boulders over what previously was a marshy site (Cooley and others, 1977). The 1966 levee is $6 \mathrm{ft}$ above the channel bed of 1986 downstream of Natchi Canyon, whereas the debris-flow deposit $\mathrm{Z}$ and associated driftwood is $12 \mathrm{ft}$ above the channel. Between sites B and C (fig. 2), the debris flow was confined in a narrow, boulder-clogged channel with a steplike appearance (Cooley and others, 1977, fig. 29B).
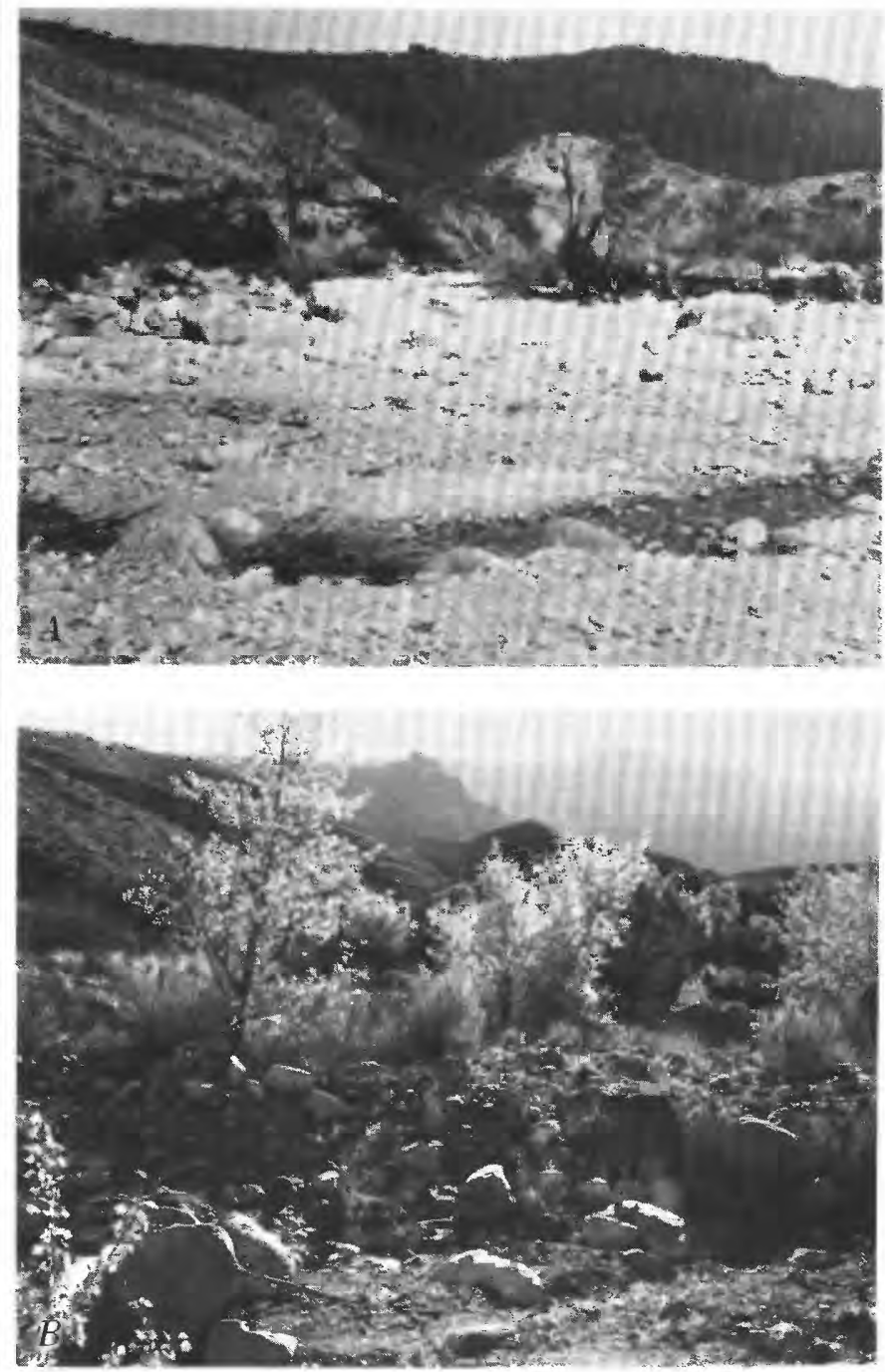

Figure 5.-Lava Creek, 0.2 mile upstream from the confluence with Chuar Creek. View A (March 1967) shows that the debris flow of 1966 has created a nearly level denuded channel. View $B$ (March 1986) shows an entrenched channel and post-1966 debris-flow deposits in the foreground. See site C, figure 2, for location. 
Little depositional evidence for the 1966 debris flow is preserved in this reach, and deep scour holes suggest this to be a reach of many transformations between laminar and turbulent flow (Fisher, 1983) and predominantly supercritical flow conditions. The reach immediately above MacDonald Spring (site D, fig. 2) is similar.

At site $\mathrm{E}$, the debris flow was not confined by lateral terraces for $0.2 \mathrm{mi}$. A large levee formed and was repeatedly breached as the flow deposited lobate splays of sediment. The critical thickness of the deposit at which the debris flow stopped moving ranged from 1.6 to 2.3 $\mathrm{ft}$, and boulders 2 to $5 \mathrm{ft}$ in diameter compose the preserved levee. The volume of sediment preserved in the lobes suggests that this debris flow was sustained for a relatively long time period rather than consisting of a single, short pulse behind a moving boulder dam. The debris flow of 1966 inundated a 6-foot-high terrace 800 $\mathrm{ft}$ upstream from the Colorado River and deposited sediments 0.1 to $1.3 \mathrm{ft}$ thick composed of poorly sorted particles and matrix-supported boulders.

Particle-size distributions for the debris flow of 1966 indicate a poorly sorted and coarse-grained deposit (fig. 6 ). The debris flow had 4 to 5 percent silt and clay and about 30 to 35 percent sand. One boulder at site F (fig. 2) that was transported during the debris flow of 1966 had a median diameter of $4.8 \mathrm{ft}$ and weighed an estimated 9 tons. More commonly observed boulders were 1 to $2 \mathrm{ft}$ in diameter. Reconstitution of debris-flow deposits from the Lava-Chuar Creek drainage indicated a water content of 21 to 24 percent by volume.

\section{DISCHARGE CALCULATION}

Superelevation evidence deposited from the passage of the debris flow of 1966 around a $90^{\circ}$ bend was surveyed

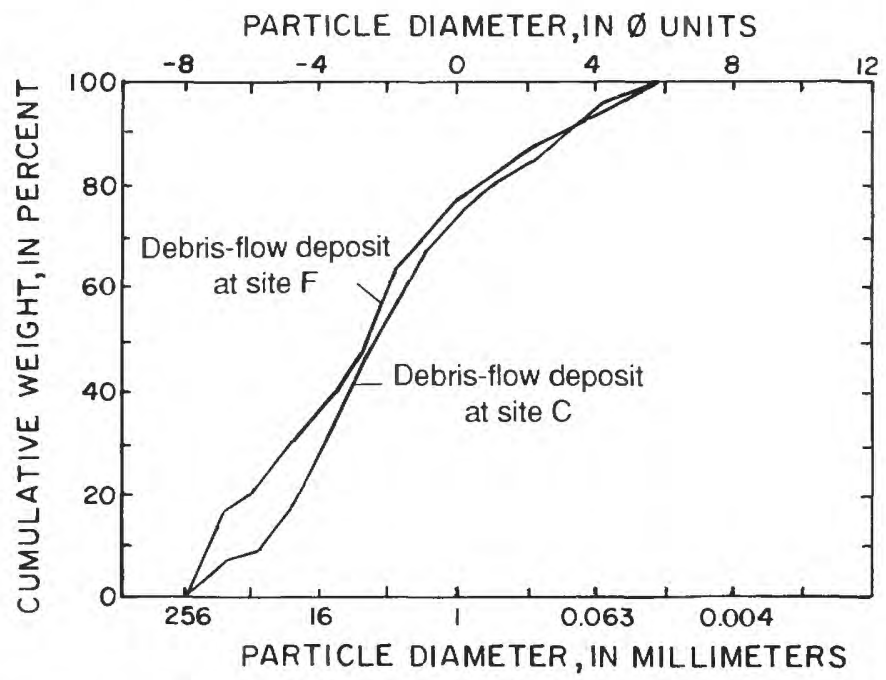

FIGURE 6.-Particle-size distributions of the debris flow of 1966 in the Lava-Chuar Creek drainage. See figure 2 for locations of sites.
0.2 mi upstream from the Colorado River (site F, fig. 2). The 12-foot-thick debris-flow deposit was preserved against a near-vertical cliff of Dox Formation. The radius of curvature of the centerline of the channel is $37 \mathrm{ft}$, whereas the channel width is $110 \mathrm{ft}$. This apparent discrepancy results from the combination of a bend with a low radius of curvature and a width that includes flow over the point bar on the inside of the bend, and may invalidate the assumption that all streamlines follow the same radius of curvature (see section "Hydraulics of Debris Flows"). A velocity of $12 \mathrm{ft} / \mathrm{s}$ was estimated on the basis of an elevation difference $\left(\Delta h_{s}\right)$ of $13.3 \mathrm{ft}$ between the inside and outside high-water marks on the bend (table 2). The velocity could range from 10 to $14 \mathrm{ft} / \mathrm{s}$ because of uncertainties in the radius of curvature $\left(R_{c}\right)$.

Determination of the cross-sectional area of flow was unexpectedly difficult. The cross-sectional area at the superelevation site was about 3.5 times larger than upstream or downstream cross sections. The discharge calculated using the area at the superelevation site is $14,200 \mathrm{ft}^{3} / \mathrm{s}$. If this discharge is correct, use of equation (4) suggests that the velocity must increase downstream to $46 \mathrm{ft} / \mathrm{s}$ over $250 \mathrm{ft}$. Similarly, the flow would have to decelerate from 41 to $12 \mathrm{ft} / \mathrm{s}$ over $125 \mathrm{ft}$ as the flow enters the bend. The problem with large cross-sectional areas at superelevation sites compared with upstream and downstream cross sections occurred in the other two tributaries studied, and a justification for the discharge calculations is presented in the section "Similarities and Contrasts Among the Drainages."

The discharge for the 1966 debris flow was estimated from an average of the cross sections $125 \mathrm{ft}$ upstream and $250 \mathrm{ft}$ downstream, respectively, from the site of maximum superelevation. Using an average area of $330 \mathrm{ft}^{2}$, the debris flow of 1966 had a peak discharge of 4,000 $\mathrm{ft}^{3} / \mathrm{s}$ (table 2 ) with a Froude number between 1.0 to 1.4 . The average water content of reconstituted samples is 22.5 percent, hence the peak sediment and water discharges are estimated to be 3,100 and $900 \mathrm{ft}^{3} / \mathrm{s}$, respectively.

\section{MONUMENT CREEK DRAINAGE}

Monument Creek, $3.3 \mathrm{mi}^{2}$ in area, heads on the Coconino Plateau on the south side of the Colorado River (figs. $1,7)$. The bedrock geology of this drainage consists of the entire Paleozoic section (Huntoon and others, 1986), with the Permian Kaibab Limestone and Coconino Sandstone, Mississippian Redwall Limestone, and Cambrian Muav Limestone forming prominent cliffs. The Permian Hermit Shale and Permian and Pennsylvanian Supai Group form benches in the otherwise vertical cliffs. An erosional surface in the Cambrian Bright Angel Shale and underlying Tapeats Sandstone forms the Tonto Platform, which 
is present in much of the Grand Canyon. Monument Creek cuts through the Precambrian Vishnu Schist in the 1.5 mi upstream from the Colorado River and forms a deep, narrow canyon. Topographic relief in the drainage basin is $4,500 \mathrm{ft}$ and the average channel slope is 0.2 .

On July 27, 1984, a thunderstorm centered over the eastern part of Monument Creek initiated a debris flow. Rainfall recorded at Grand Canyon, about $1 \mathrm{mi}$ from the headwaters (fig. 1), indicates a total of $1.08 \mathrm{in}$. for the storm, with 0.92 in. falling in 1 hour. These rainfall totals are not unusual for the station and the month of July 1984 was not unusually wet. However, the high-intensity rainfall triggered a free-falling avalanche, which fell $2,000 \mathrm{ft}$ into the canyon from the Esplanade Sandstone on the Mojave Wall (fig. 7). The coarse, poorly sorted, and angular debris filled the channel to a depth of $20 \mathrm{ft}$ and created a debris dam that had not been breached by 1986 . The avalanche transformed into a debris flow with the addition of runoff and water in the channel. Other eastern tributaries of Monument Creek also had debris flows initiated by smaller slope failures in the Supai Group (fig.

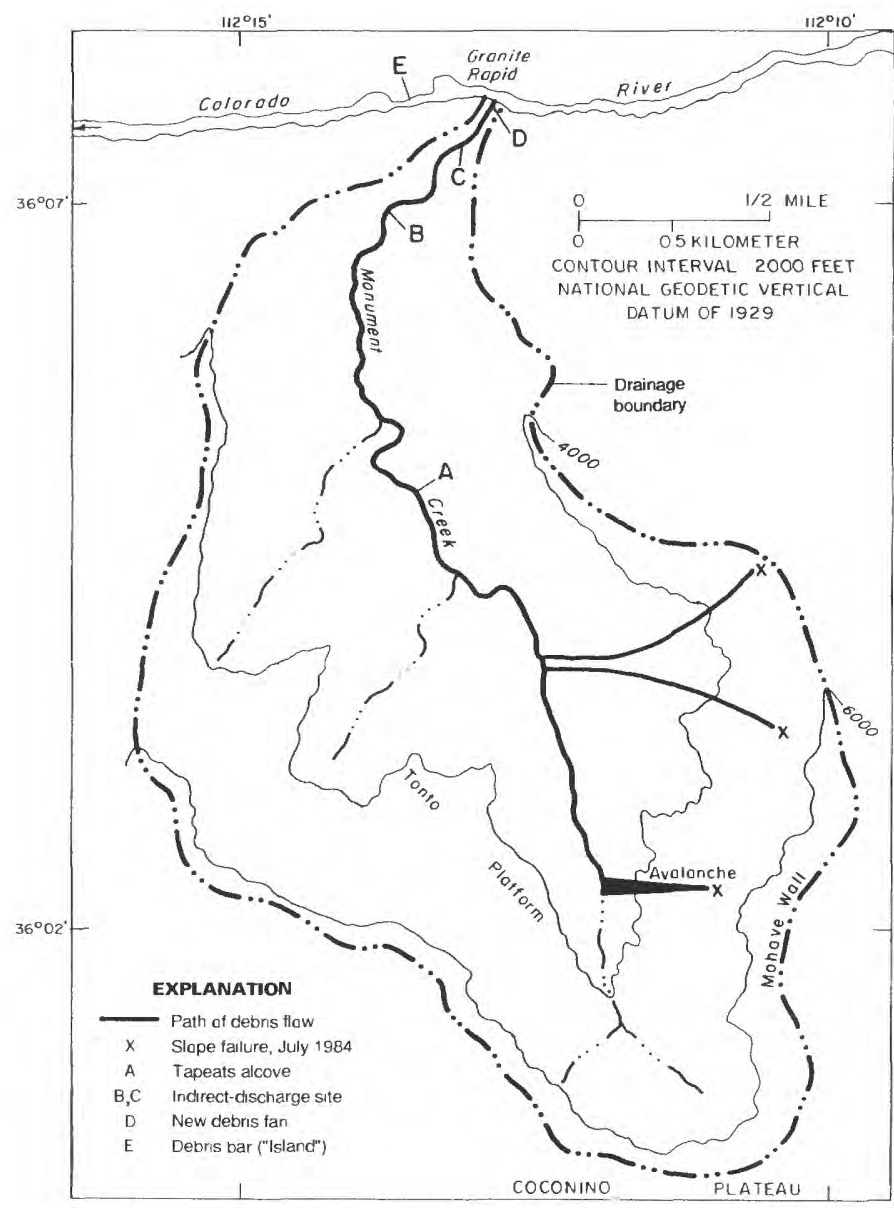

FiguRe 7.-Monument Creek drainage at mile 93.5 on the Colorado River. See figure 1 for location.
7). The resulting debris flow traveled $2.8 \mathrm{mi}$ to the Colorado River, where deposition caused a significant constriction of the Colorado River at Granite Rapid (fig. 8).

\section{STRATIGRAPHY}

Deposits preserved in terraces and associated scarred catclaw trees indicate that a historic debris flow occurred before 1984 (fig. 9). Ring counts on scarred and healed catclaw trees suggest that this debris flow occurred 20 to 25 years before 1986 . The heights of the scarred trees are roughly equivalent to or slightly higher than the stage of the debris-flow peak of 1984. Aerial photographs, however, do not reveal obvious channel changes in Monument Creek after 1965 . The pre-1984 debris flow was initiated near or upsteam from the avalanche source for the 1984 debris flow. Locally, this flow deposited 3-foot-thick sediments and had a stage $28 \mathrm{ft}$ above the channel.

Evidence for older debris flows in Monument Creek is scanty because of poor exposures and erosion during the

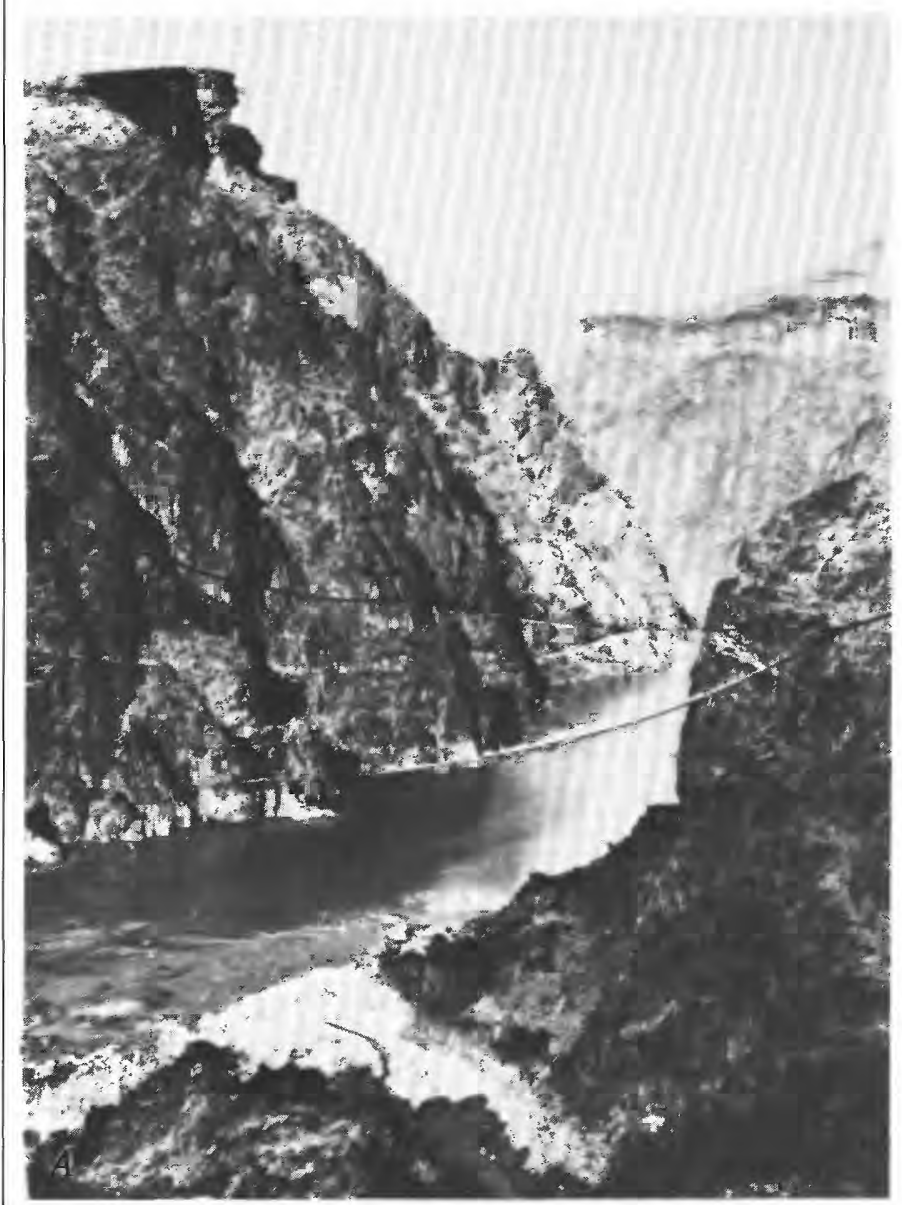

FIGURE 8.-Mouth of Monument Creek. In view $A$ (September 1872), the discharge in the Colorado River apparently is between 20,000 and 25,000 cubic feet per second. Curved lines in the center of the photograph are cracks in the original glass-plate negatives. In view 
historic events. Monument Creek has two terraces composed of layered debris-flow deposits-a low terrace that was inundated in 1984 and a high terrace covered with mesquite and catclaw trees that was not inundated in 1984. At Tapeats Alcove (site A, fig. 7), an exposure of the high terrace showed three prehistoric debris-flow deposits, one of which had a radiocarbon age of $170 \pm 90$ yr B.P. (A-4542). Lack of longitudinal correlation of these deposits with others along Monument Creek, however, precludes any meaningful discussion of the frequency of prehistoric debris flows.

LONGITUDINAL VARIATION IN THE 1984 DEBRIS-FLOW DEPOSITS

The debris flow of 1984 was initiated at slope failures on the east side of the drainage (fig. 7). The largest slope failure, an avalanche, hit a water-filled channel and splattered mud and debris as much as $200 \mathrm{ft}$ above the channel on the west side of the drainage. The particle-size

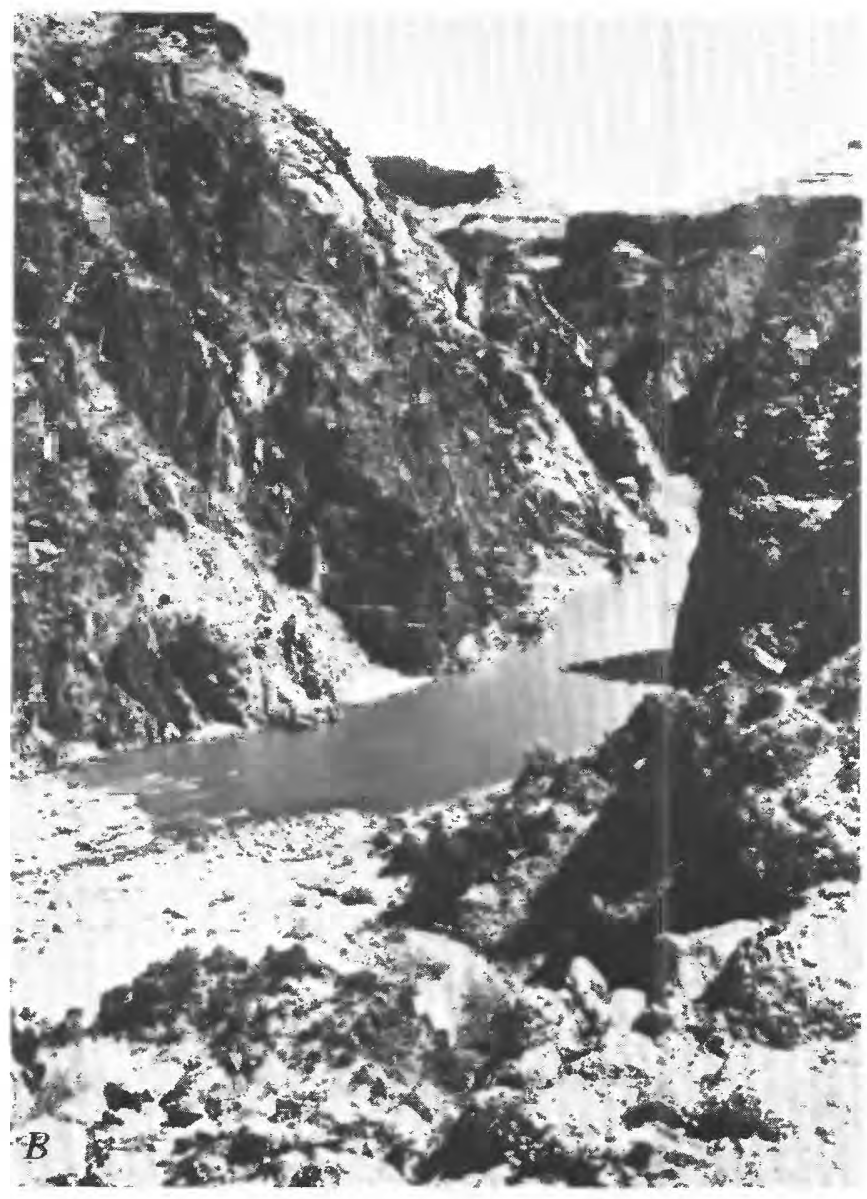

$B$ (September 1968), the discharge in the Colorado River is about 8,000 cubic feet per second. The river appears to be more constricted than in 1872 despite differences in discharge, and a debris flow that occurred 2 to 7 years prior to the photograph date may have contributed distribution near the slide (fig. $10 B$ ) shows that the flow was poorly sorted with coarse clasts as much as $256 \mathrm{~mm}$ in diameter. A lithological count of clasts revealed that 64 percent were sandstones from the Supai Group and 36 percent were from the Redwall Limestone.

Downstream from the avalanche, the debris flow may have undergone several transformations from laminar to turbulent flow before reaching Tapeats Alcove (site A, fig. 7). Lodged boulders created local 3- to 10-foot drops in the channel bed; recessional deposits upstream from these drops are clearly of debris-flow origin, whereas hyperconcentrated flow deposits occur downstream from the drops. A particle-size distribution measured above Tapeats Alcove (fig. 10B) shows a poorly sorted debrisflow matrix with 40 percent sand.

Two small tributaries of Monument Creek downstream from the avalanche contributed debris flows to the main channel. A debris flow from the downstream tributary occurred after the peak, as inferred from a superelevation of the flow over the 7- to 10-foot-high banks of Monument

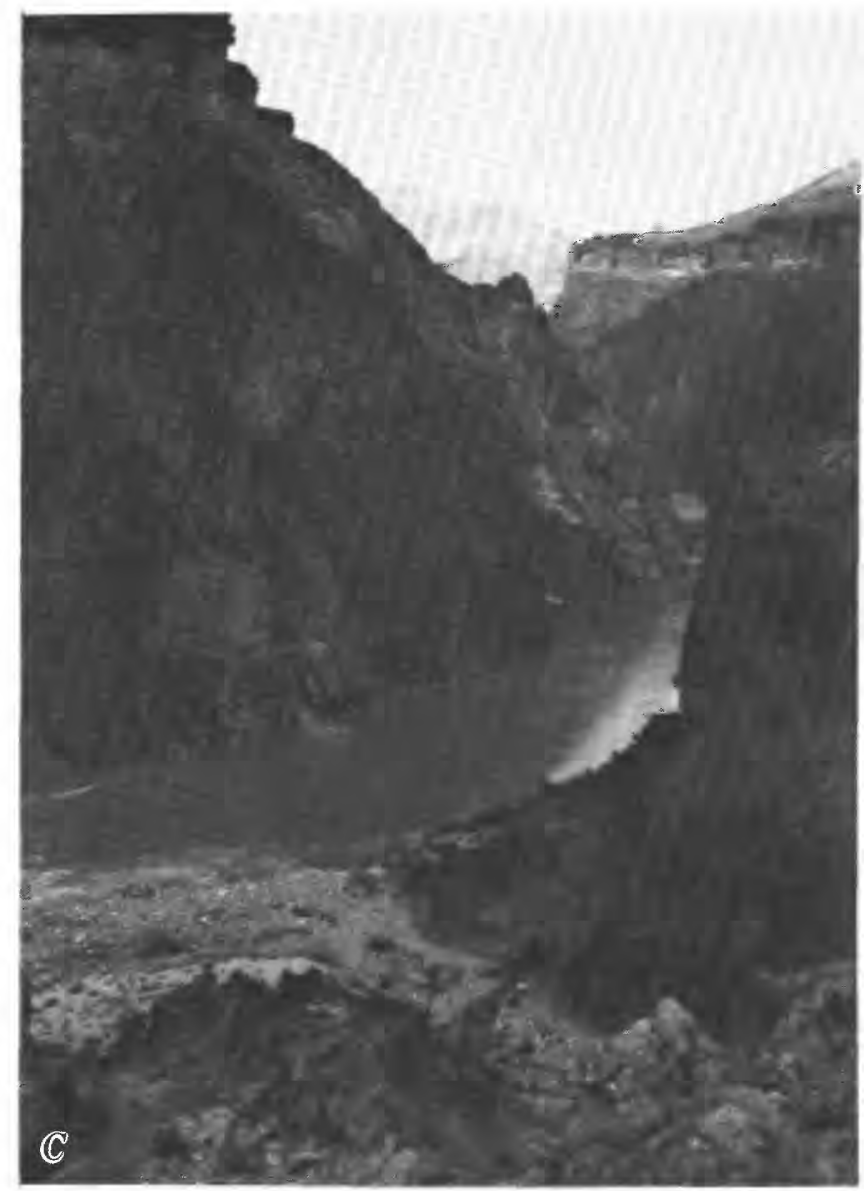

to the constriction. In view $C$ (April 1986), the discharge in the Colorado River is 28,500 cubic feet per second. The 1984 debris flow has constricted the river significantly, especially in comparison with 1872 conditions. 
Creek at the confluence. The flow remained overbank 230 $\mathrm{ft}$ downstream and may have caused a recessional debrisflow pulse. No debris from these two tributaries remains in the channel of Monument Creek, indicating that flow in the main channel was still erosive enough to remove the additional sediments.

The peak of the debris flow sustained its cohesive properties until it reached the Colorado River. Superelevation marks appear on most bends, and lateral levees were deposited in channel irregularities. In the narrow bedrock canyon $0.25 \mathrm{mi}$ downstream from Tapeats Alcove, three deposits with a lower stage than the peak discharge are preserved. These deposits are suggestive of recessional debris and (or) hyperconcentrated flows following the main pulse. The particle-size distribution for the debris flow in this section (fig. 10C) indicates an increased percentage of boulders and a sand content of 30 percent. The additional boulders were probably entrained from the bed and terraces. Below site B, one boulder transported by the flow is $9 \mathrm{ft}$ in diameter; a second rectangular block

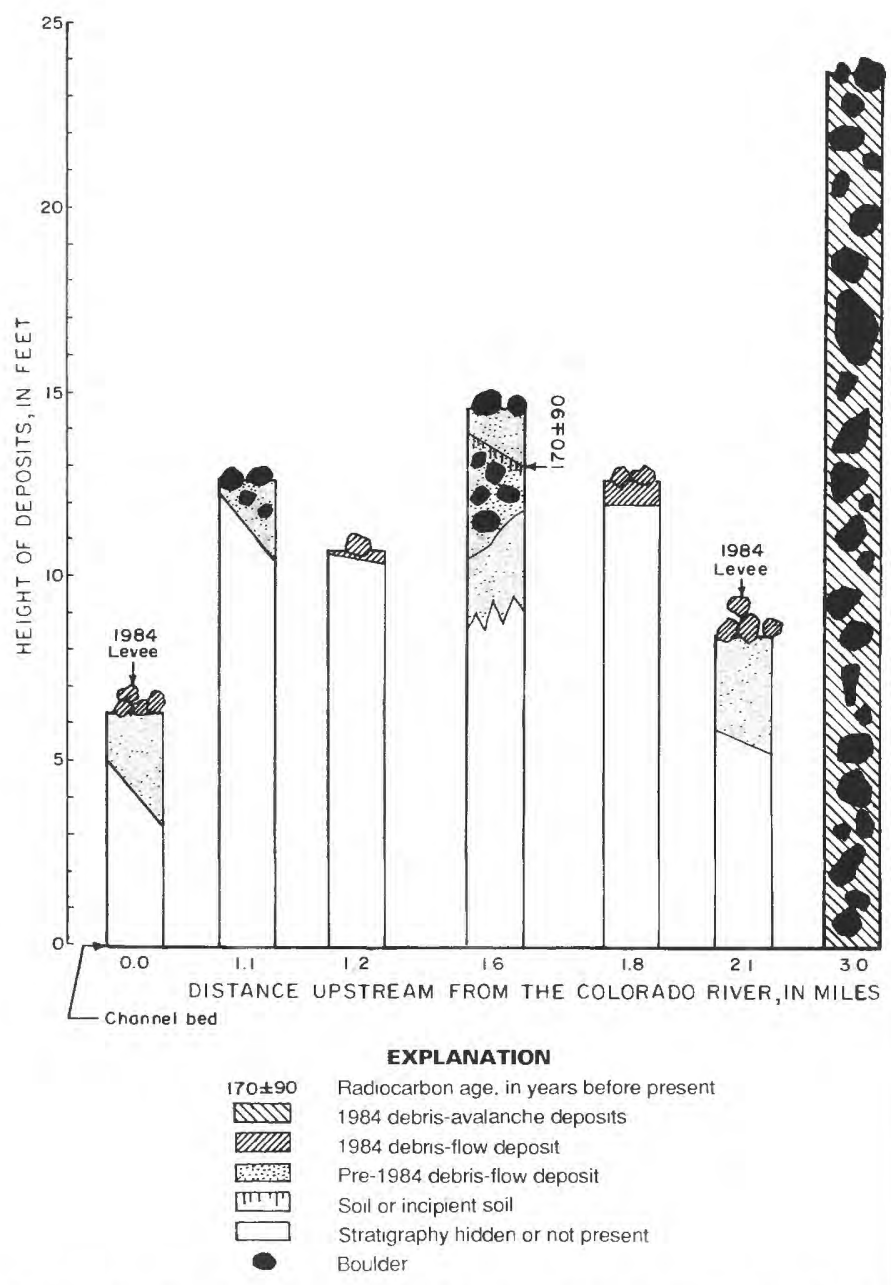

FiguRE 9.-Stratigraphy of debris-flow deposits in the Monument Creek drainage. has an average length of $8 \mathrm{ft}$ and weighs an estimated 37 tons.

Near the Colorado River, the deposits in the center of the channel abruptly change to well-sorted and imbricated boulder bars (fig. $8 C$ ) superficially resembling sieve deposits (Hooke, 1967). The debris flow at this point was confined and deposition occurred to an average depth of $5 \mathrm{ft}$. At locally unconfined sites, the critical thickness of the debris flow was $3 \mathrm{ft}$. The particle-size distribution (fig. $10 D$ ) shows a well-sorted cobble deposit with a median diameter of $32 \mathrm{~mm}$, although poorly sorted matrix was found on the channel margin. We speculate that either recessional or post-event streamflow, dewatering of the deposit after deposition, or positive pore pressures from springs in the channel bed caused the nearly complete removal of the debris-flow matrix from the boulders and its subsequent transport into the Colorado River.

\section{DISCHARGE CALGULATIONS}

Superelevations resulting from the debris flow of 1984 were measured at three sites on Monument Creek in reaches $0.3,0.5$, and $1.5 \mathrm{mi}$ upstream from the Colorado River. At Tapeats Alcove (site A, fig. 7), an elevation difference of $4.7 \mathrm{ft}$ was measured from mudlines on the wall of a prominent overhang. Channel geometry at the site (table 3) was used to calculate a velocity of $12 \mathrm{ft} / \mathrm{s}$ for the debris flow. The bed of the channel consists of large blocks of Tapeats Sandstone, which had fallen from the roof of the alcove either before or during the debris flow. The

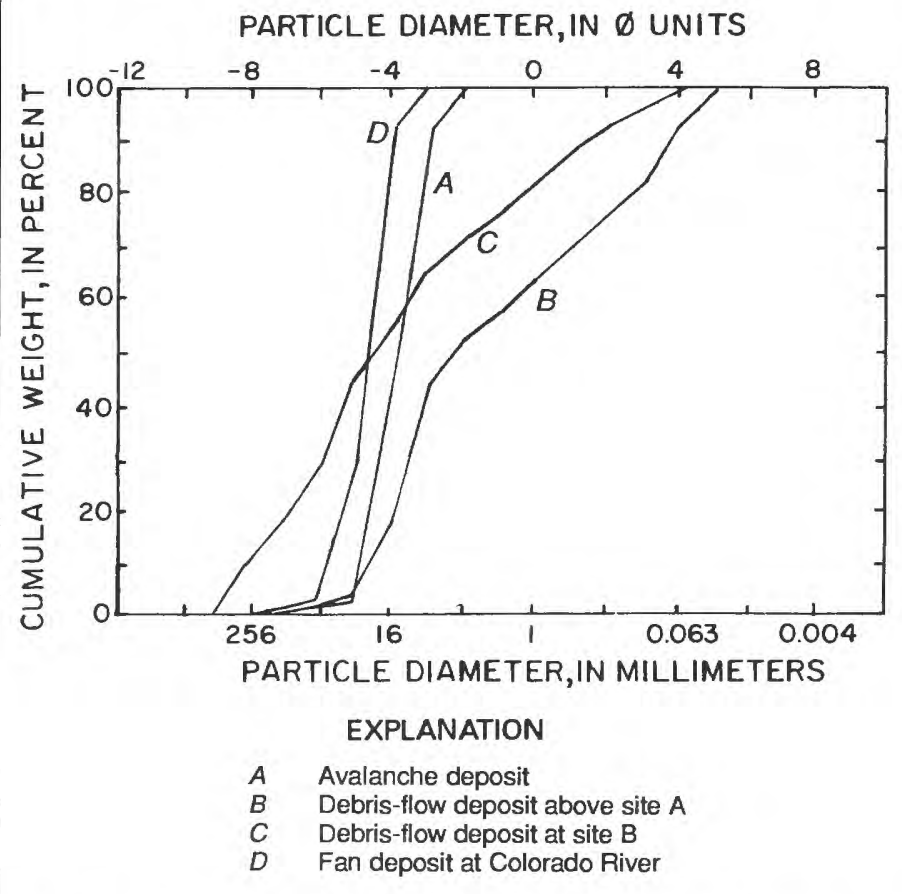

FIgURE 10.-Particle-size distributions of the debris flow of 1984 in the Monument Creek drainage. See figure 7 for locations of sites. 
cross sections measured at the superelevation mark and a wide, eroded reach upstream had twice the area of a cross section that was measured $50 \mathrm{ft}$ downstream (table 3 ). We used the cross-sectional area measured $50 \mathrm{ft}$ downstream $\left(320 \mathrm{ft}^{2}\right)$ to calculate a peak discharge of $3,800 \mathrm{ft}^{3} / \mathrm{s}$ for the debris flow. Reconstitution of a debrisflow matrix sample taken upstream indicates a water content of 32 to 34 percent by volume.

At site B (fig. 7), resistant Vishnu Schist forms the bed of the channel. A maximum superelevation of $3.7 \mathrm{ft}$ was measured on this bend (fig. 11), which is $0.5 \mathrm{mi}$ upstream of the Colorado River. A runup elevation of $2.1 \mathrm{ft}$ was measured above the superelevation line. Velocities of 11.0 and $11.5 \mathrm{ft} / \mathrm{s}$ were calculated from the superelevation and runup evidence, respectively (table 4). As observed previously, cross sections in the bend had significantly larger areas than upstream and downstream cross sections; hence, the average of the upstream and downstream cross sectional areas $\left(320 \mathrm{ft}^{2}\right.$; table 4$)$ was used. The resulting discharge is between 3,600 and $4,000 \mathrm{ft}^{3} / \mathrm{s}$, depending upon whether velocity was calculated from runup or superelevation evidence. The water content of the peak flow, reconstituted from a sample collected near the site, was 27 to 29 percent by volume.

At site C, $0.3 \mathrm{mi}$ from the Colorado River (fig. 7), superelevation marks were preserved on a bend having considerable debris-flow deposition. No controls on channel depth are present in this reach and either aggradation or degradation may have occurred. Survey data revealed an ambiguous superelevation because of a slight channel expansion (97 to $106 \mathrm{ft}$ ) over a 20 -foot distance. Use of the respective elevation differences (3.4 or $4.6 \mathrm{ft}$ ) with the associated width resulted in a velocity between 11.9 and $13.2 \mathrm{ft} / \mathrm{s}$. Possible deposition after the peak flow in upstream sections precluded any meaningful calculation of cross-sectional area. A cross section measured $45 \mathrm{ft}$ downstream from the lower superelevation site yielded an area of $320 \mathrm{ft}^{2}$, although the actual area might be considerably larger due to possible deposition after the peak flow. The resulting discharge ranged from 3,800 to 4,200 $\mathrm{ft}^{3} / \mathrm{s}$ with a Froude number between 1.2 and 1.4 (table 5 ). The water content of the flow was probably similar to that estimated for site B (28 percent).

\section{SEDIMENT VOLUME}

The new debris fan at the Colorado River (fig. 8) was surveyed to estimate the volume of material deposited during the debris flow of 1984. The debris flow entered and partially dammed the Colorado River (Mike Yard, boatman, Humphrey Summit Adventures, Flagstaff, Arizona, oral commun., 1986), which had a mean discharge of about $24,000 \mathrm{ft}^{3} / \mathrm{s}$ on July 25 . Observers noted that the newly formed fan contained significant amounts of matrix immediately after the debris flow, but that the mud was quickly eroded from the fan. Higher discharges on the Colorado River in the fall of 1984 and spring of 1985 partially eroded the newly formed fan (Mike Yard, oral commun., 1986).

Without knowing the exact geometric configuration of the fan after the event, a volume of sediment was estimated on the basis of four hypothesized scenarios of deposition (table 6) and extension of the debris fan remaining in 1986 into the Colorado River. First, we assumed the deposit that remained in April 1986 was the entire extent of the deposition; this scenario results in an unrealistically low estimate of sediment volume. Second, we assumed that the debris flow completely dammed the river at Granite Rapid; this scenario results in an unrealistically
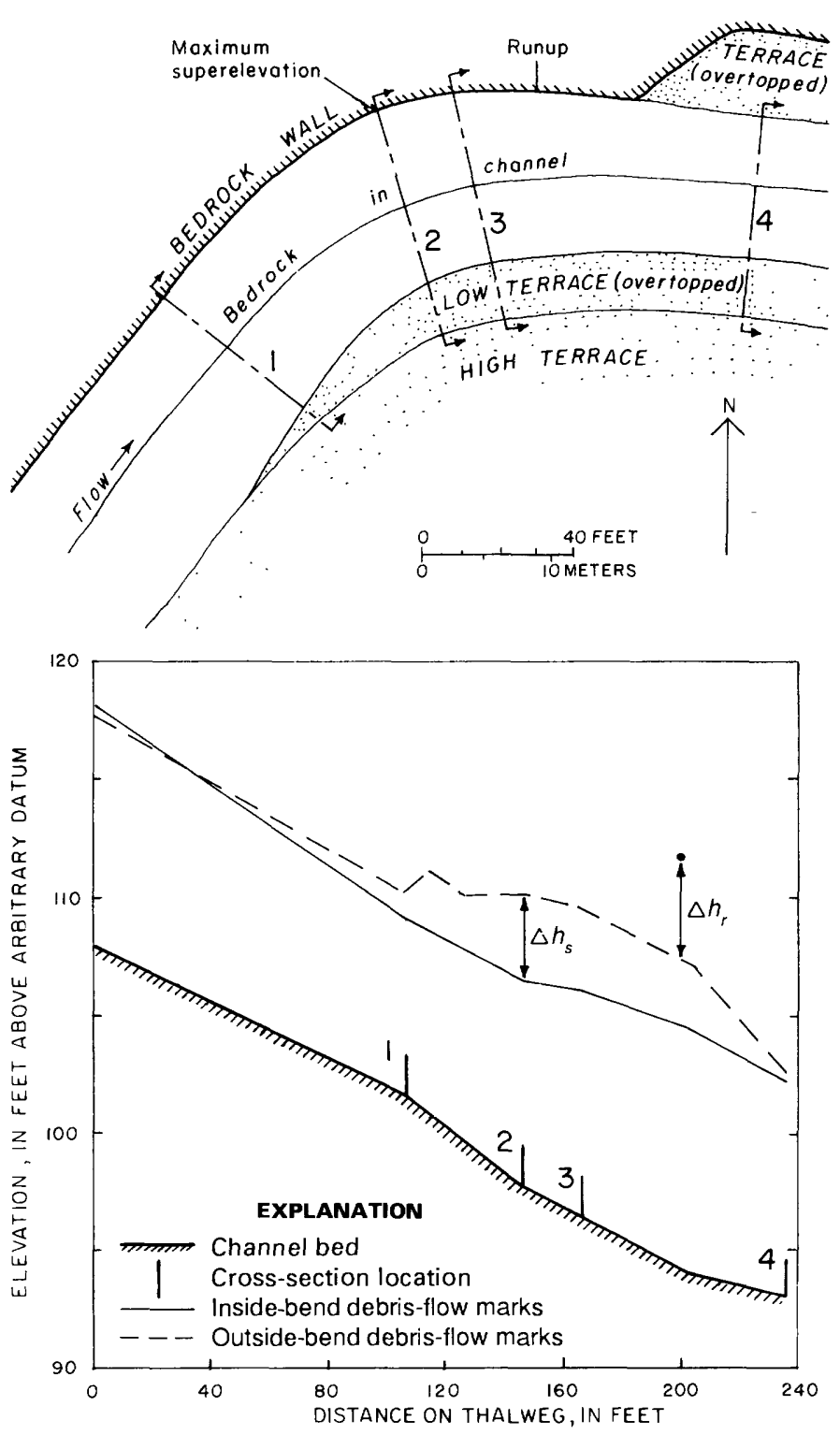

FiguRe 11.-Plan map and longitudinal profile for indirect-discharge site B in Monument Creek, 0.5 mile upstream from the Colorado River. 
high estimate of sediment volume. Two additional scenarios of partial damming of the river that more realistically paralleled the eyewitness report also were assumed. River depth at Granite Rapid was $11 \mathrm{ft}$ at a discharge of $25,000 \mathrm{ft}^{3} / \mathrm{s}$ in April 1984 (R.P. Wilson, U.S. Geological Survey, written commun., 1986). A triangular cross section was assumed for the 200-foot-wide channel. The depth of the fan deposit was estimated at $5 \mathrm{ft}$ on the basis of natural exposures and the 3-foot depth of channel filling was suggested from critical thicknesses of the deposit on the fan margin.

The calculated volumes (table 6) indicate a range of possible volumes of sediment deposited during the debris flow. The most realistic estimate of sediment volume (scenario 3 ; table 6), with the debris flow partially damming the river, is about $300,000 \mathrm{ft}^{3}$. Using a measured sand content of 35 percent and assuming that all of the debris-flow matrix entered the Colorado River, thus explaining the fines-depleted boulder bar, the estimated volume of sand-sized particles is $84,000 \mathrm{ft}^{3}$ for this scenario. The estimated volume of sand ranged from 56,000 to $150,000 \mathrm{ft}^{3}$ among the scenarios (table 6). This calculation indicates that a substantial volume of sand entered the Colorado River during the 1984 debris flow, although the exact volume is uncertain.

Further assumptions were made concerning the debris fan to estimate the minimum elapsed time of the discharge. Sedimentologic evidence suggests a saw-toothed hydrograph of unknown duration (fig. 12). At least three recessional debris-flow surges followed the initial pulse although their stages were much lower (1-3 ft compared with greater than $10 \mathrm{ft}$ ). Similar multipeaked hydrographs of debris flows have been reported elsewhere (Hungr and others, 1984; Pierson, 1985). Flow between the surges may have been hyperconcentrated (see Pierson, 1985). We assumed that (1) the entire volume of material reaching the debris fan and the Colorado River was delivered in the first pulse and (2) the hydrograph shape could be modeled as a square wave with the recessional debris flows not reaching the debris fan (fig. 12). The resulting minimum duration times (table 6), which range from 1 to nearly 3 minutes, demonstrate the probable transitory nature of this event.

\section{GRYSTAL GREEK DRAINAGE}

The Crystal Creek drainage, $43.3 \mathrm{mi}^{2}$ in area, is the largest of the three drainages studied (figs. 1, 13). The geology of this drainage consists of the Paleozoic section of Kaibab Limestone through the Muav Limestone that forms prominent cliffs in the headwaters, the nearly flat Tonto Platform developed on top of the Tapeats Sandstone, and the Vishnu Schist forming deep canyons along the lower $5 \mathrm{mi}$ of the drainage (Huntoon and others, 1986). The topographic relief in the drainage is $6,500 \mathrm{ft}$ and the average channel slope is 0.07 .

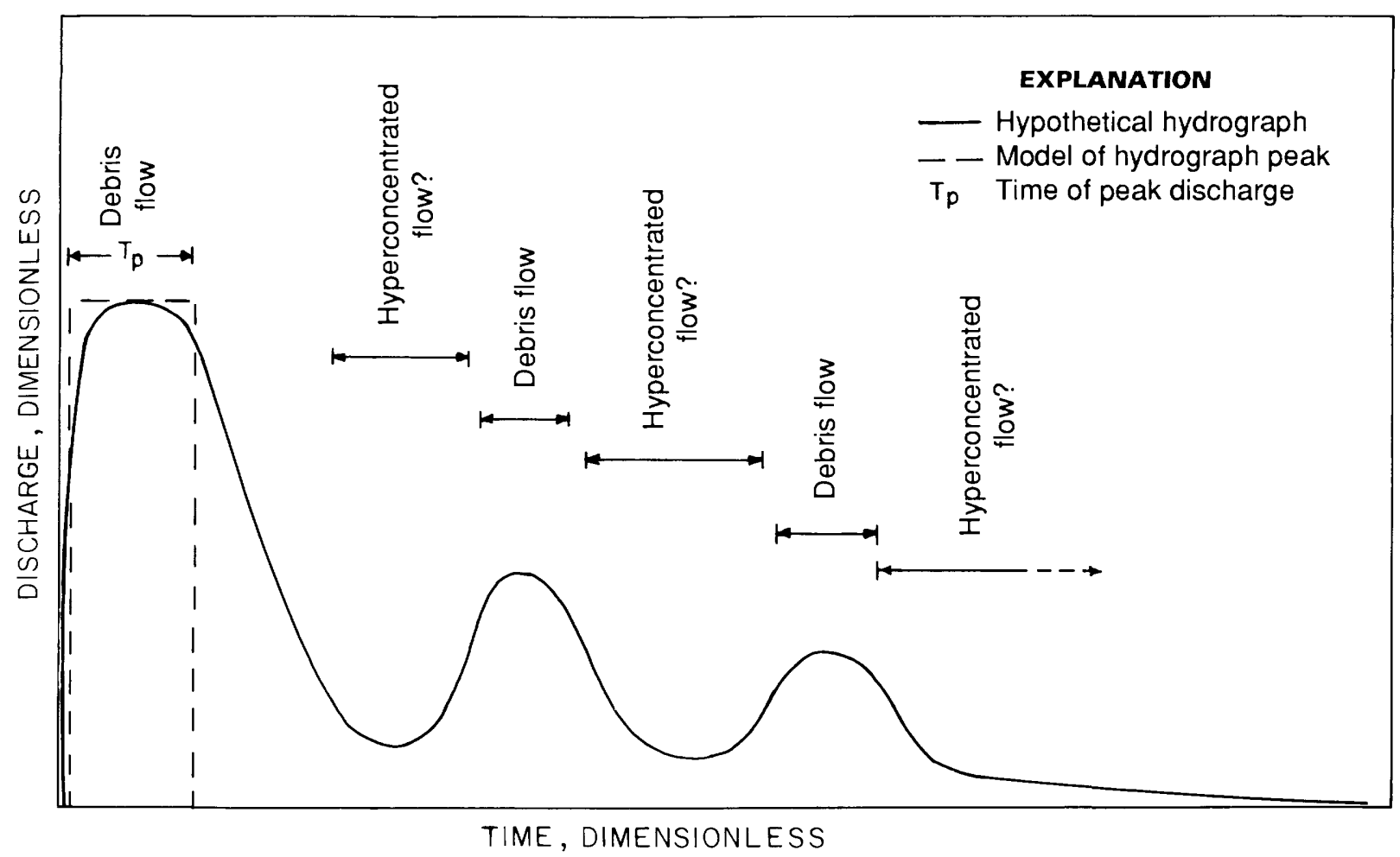

FIGURE 12.-Hypothetical hydrograph of the debris flow of 1984 in Monument Creek as suggested by stratigraphic evidence. 
A debris flow occurred during the storm in December 1966 that also initiated a debris flow in the Lava-Chuar Creek drainage (Cooley and others, 1977). Because of the sustained nature of the storm, the flood consisted of streamflow of unknown discharge followed by a large debris flow and subsequent streamflow of moderate discharge (Cooley and others, 1977). The debris flow reportedly had either a single pulse or multiple pulses in the lower parts of the drainage. The debris flow started at 11 slope failures in the headwaters of Milk Creek (fig. 13) and travelled $13 \mathrm{mi}$ through Milk Creek and down Dragon and Crystal Creeks to the Colorado River.

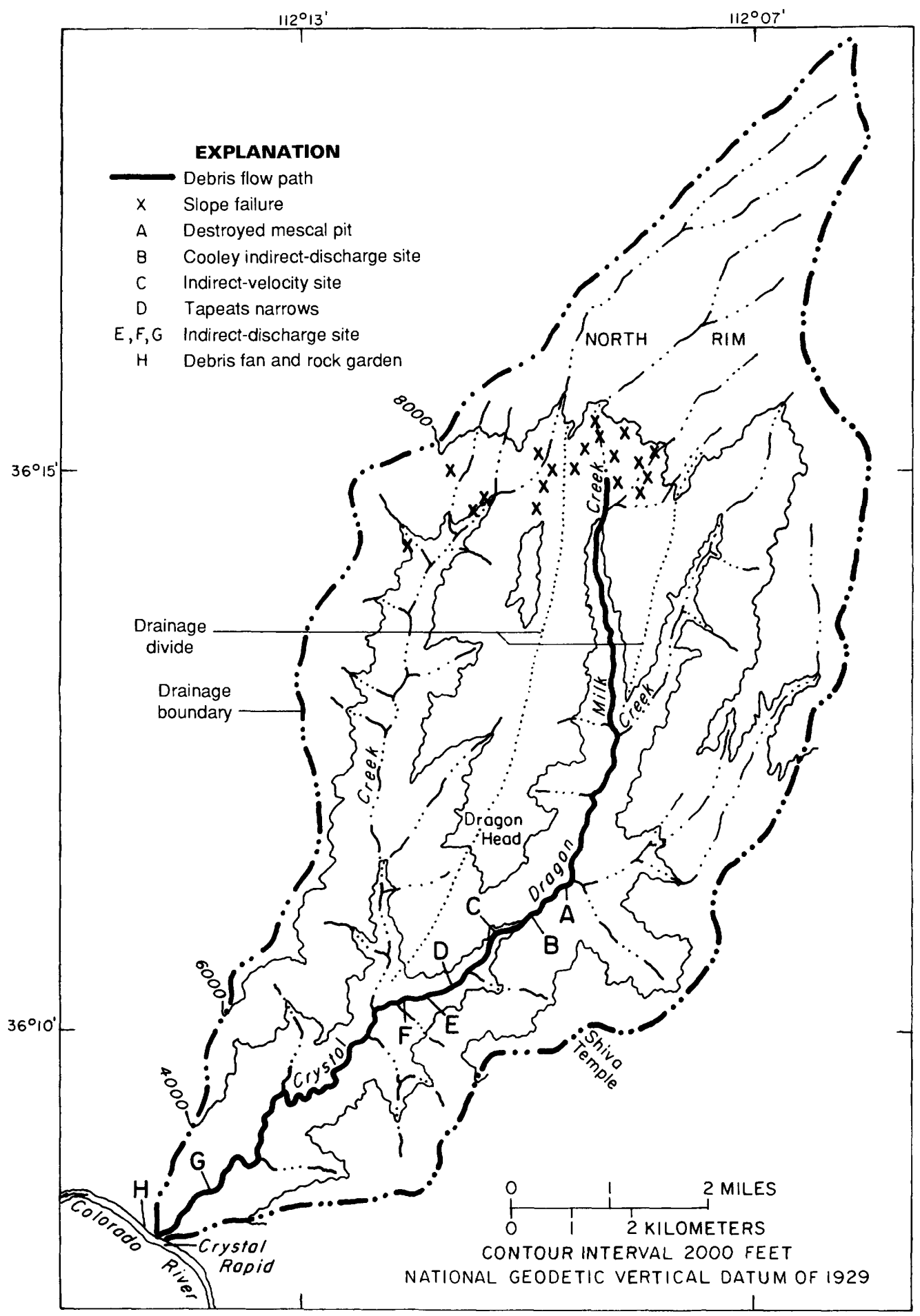

FIGURE 13.-The Crystal Creek drainage at mile 98.2 on the Colorado River. See figure 1 for location. 
Streamflow that followed the debris flow partially obliterated the lower parts of mudlines and caused significant channel erosion (Cooley and others, 1977). The debris fan resulting from the debris flow of 1966 significantly constricted the Colorado River at Crystal Rapid.

Cooley and others (1977) calculated discharges for the different phases of the flood from evidence at several sites in the Crystal Creek drainage. A peak flow of $100 \mathrm{ft}^{3} / \mathrm{s}$ was estimated for Crystal Creek above its confluence with Dragon Creek (fig. 13), indicating that this part of the drainage added little streamflow to the flood. In contrast, Cooley and others (1977) estimated a discharge of 29,000 $\mathrm{ft}^{3} / \mathrm{s}$ for the peak of the debris flow on Dragon Creek (site $\mathrm{B}$, fig. 13) using the slope-area method and a Manning's $\mathrm{n}$ value of 0.070 . Cooley and others (1977) calculated a velocity of $23 \mathrm{ft} / \mathrm{s}$ with a Froude number of 1.1 to 1.2 for the flow. A discharge of $1,000 \mathrm{ft}^{3} / \mathrm{s}$ was estimated for streamflow on Dragon Creek upstream from the confluence with Milk Creek. This discharge could have contributed to the post-debris-flow streamflow in the drainage.

The debris flow of 1966 caused considerable channel change and damaged archaeological and historical sites (Cooley and others, 1977). The archaeological site (site A, fig. 13), a mescal (agave-roasting) pit probably used between A.D. 1050 and 1150, was inundated and could not be exactly located during post-flood surveys. Cooley and others (1977) concluded on the basis of this evidence that the debris flow was the largest event in 800 years with a recurrence interval of several centuries. In contrast, the recurrence interval for the flood of December 1966 on Bright Angel Creek $\left(4,000 \mathrm{ft}^{3} / \mathrm{s}\right)$ was estimated at 25 years. The 1966 debris flow obliterated a mine shaft 3 to $4 \mathrm{ft}$ above the bed of Dragon Creek just upstream from its confluence with Crystal Creek (Harvey Butchart, retired professor, Northern Arizona University, oral commun., 1986). The destruction of this shaft, which was probably dug between 1893 and 1916, indicates that large floods or debris flows had not passed the confluence of Crystal and Dragon Creeks between 1916 and 1966.

\section{STRATIGRAPHY}

Most of the depositional record of prehistoric debris flows has been eroded from the Crystal Creek drainage because of the apparent high frequency of events. Stratigraphic sections (fig. 14) indicate at least three prehistoric debris flows have passed through the 2.5-mile reach of Crystal Creek upstream from the Colorado River. A radiocarbon age of $180 \pm 70$ yr B.P. (AA-1784) from wood entrained in the lowermost of the debris-flow deposits suggests that a minimum of three debris flows have occurred in 200 years. On the basis of sedimentologic characteristics, longitudinal correlations of the deposits indicate that at least two of these flows reached a point $2.1 \mathrm{mi}$ above the Colorado River. Although we found no stratigraphic evidence of old flows between mile 2.1 and the mouth, it is reasonable to assume that the three prehistoric debris flows reached the Colorado River.

In Tapeats Narrows on Dragon Creek (site D, fig. 13), an exceptional exposure of stratigraphy revealed a complex depositional record of at least seven debris flows beneath the 1966 deposit. Interbedded sand and debrisflow deposits and complex cut-and-fill structures in the stratigraphy indicate a fluctuating bed in Dragon Creek that existed in response to debris flows. A radiocarbon age of $355 \pm 70 \mathrm{yr}$ B.P. (AA-1786) near the base suggests that six of these flows occurred in the last 300 to 400 years. A radiocarbon age of $130 \pm 50 \mathrm{yr}$ B.P. (AA-1785) on a layer of accumulated organic debris beneath the last flow before 1966 and a "modern" (near A.D. 1950; A-4541) age on the bark of a buried tree (fig. 14) suggests a high frequency of events at this site. We interpret the radiocarbon age on the tree as more reliable than the age on the litter layer.

Debris flows occur more frequently in the Crystal Creek drainage than the frequency stated by Cooley and others (1977). The 1966 debris flow is the only historic event preserved in the stratigraphy; however, evidence for lower-stage, historic debris flows may have been obliterated in 1966. On the basis of stratigraphy preserved in the lower part of the drainage, four debris flows (including the one in 1966) have reached the Colorado River in 200 years. Therefore, a debris flow that is large enough to reach the Colorado River occurs approximately every 50 years. Smaller debris flows occur at about the same frequency near the headwaters and significantly aggrade the channel and possibly store sediment in advance of larger debris flows that are capable of reaching the Colorado River.

Relocation of the camera position for photographs taken in 1967 (Cooley and others, 1977; figs. 7, 33, 34B, and 37) provided evidence for the longitudinal extent of a debris flow that occurred after 1966. At site A (fig. 13), debris-flow deposits fill the 1967 channel bottom by 2 to $3 \mathrm{ft}$, and a prominent headcut on a side channel (Cooley and others, 1977, fig. 33) has migrated upstream 5 to 10 $\mathrm{ft}$. Flow past the site of Cooley and others' indirectdischarge measurement (site B, fig. 13) shifted large boulders but caused little aggradation. The major change that is apparent in the matched photographs is the collapse of the vertical banks that were present in 1967 (fig. 15). Resurvey of this site revealed that the channel had widened by 5 to $15 \mathrm{ft}$, small talus deposits had encroached on the channel from the banks, and no aggradation had occurred on the bedrock channel. Changes caused by the post-1966 debris flow are less apparent downstream, although minor changes were observed in a comparison of aerial photographs of the fan deposit at the mouth of Crystal Creek taken in 1973 and 1984. 
LONGITUDINAL VARIATION IN

THE 1966 DEBRIS-FLOW DEPOSITS

We found stratigraphic evidence to support both the sequence of fluvial events and a multiple-pulse debris flow reported for the flood of 1966 (Cooley and others, 1977). We based much of our interpretation and identification of deposits on photographs of Crystal and Dragon Creeks contained in Cooley and others (1977); these sites were relocated in 1986 . Our descriptions provide additional insights into the nature of debris flows in this drainage and are not intended to supersede those of Cooley and others (1977).
Stratigraphic sections between 4 and 5 mi upstream from the Colorado River had "sandy sole layers" (Scott, 1985), consisting of relatively well-sorted, friable sand and gravel deposits (fig. 16), which underlie the poorly sorted debris-flow deposit. Sole layers have been interpreted as a debris flow interacting with streamflow at the front of the initial pulse (K.M. Scott, U.S. Geological Survey, oral commun., 1986). Streamflow probably was hyperconcentrated with sediment and may have been pushed down the channel by the more rapidly moving debris flow. The presence of sole layers supports the hypothesis of a flood preceding the debris flow (Cooley and others, 1977).

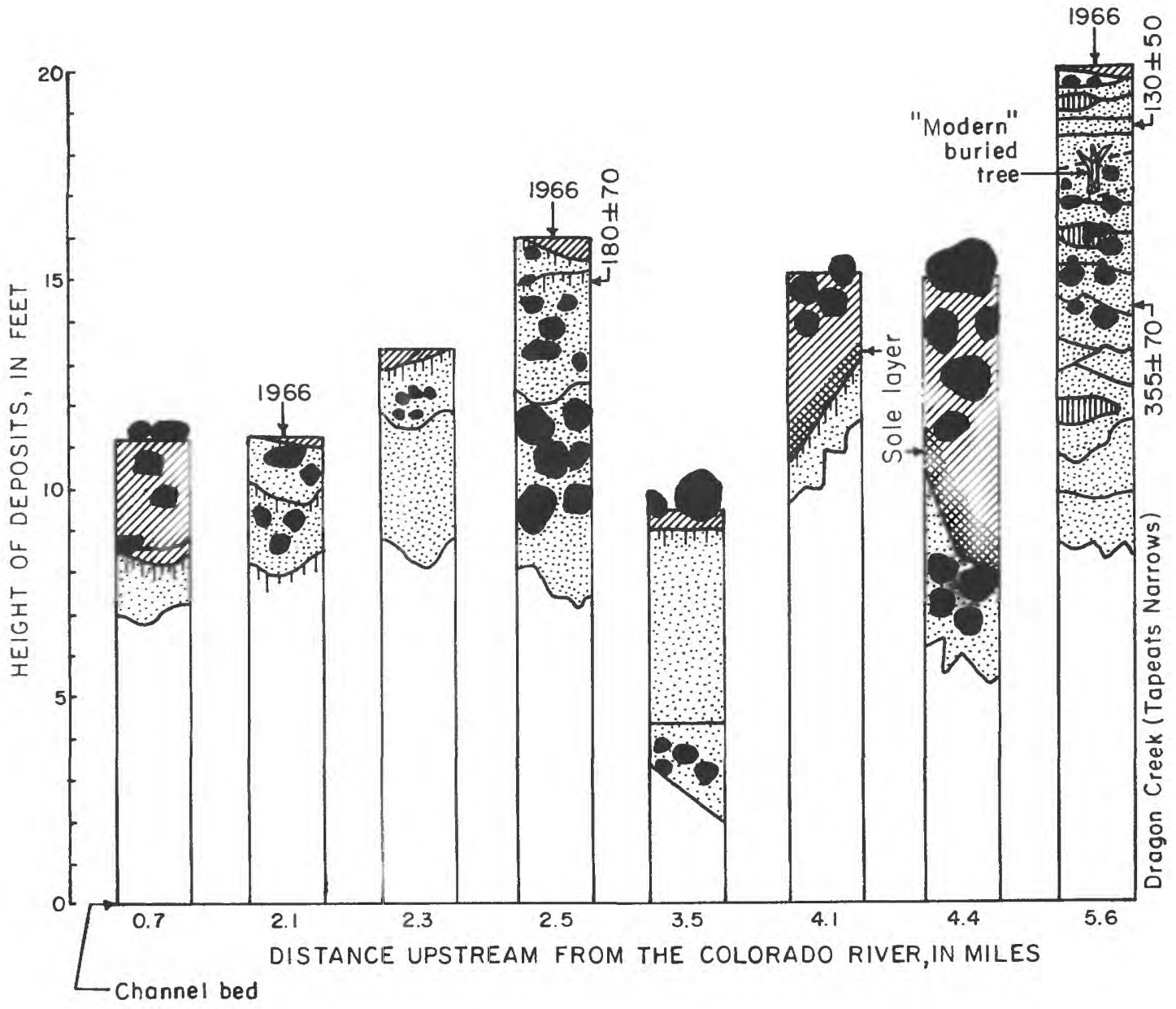

EXPLANATION

\begin{tabular}{|c|c|}
\hline $180 \pm 70$ & Radiocarbon age, in years before present \\
\hline & 1966 debris-flow deposit \\
\hline$\because a$ & Pre-1966 debris-flow deposit \\
\hline 口In⿴囗十⺝ & Hyperconcentrated or streamflow deposit \\
\hline $\begin{array}{lll}11 & 10 \\
\end{array}$ & Soil or incipient soil \\
\hline & $\begin{array}{l}\text { Stratigraphy hidden or not present } \\
\text { Boulder }\end{array}$ \\
\hline
\end{tabular}

FIGURE 14.-Stratigraphy of debris-flow deposits in the Crystal Creek drainage. 

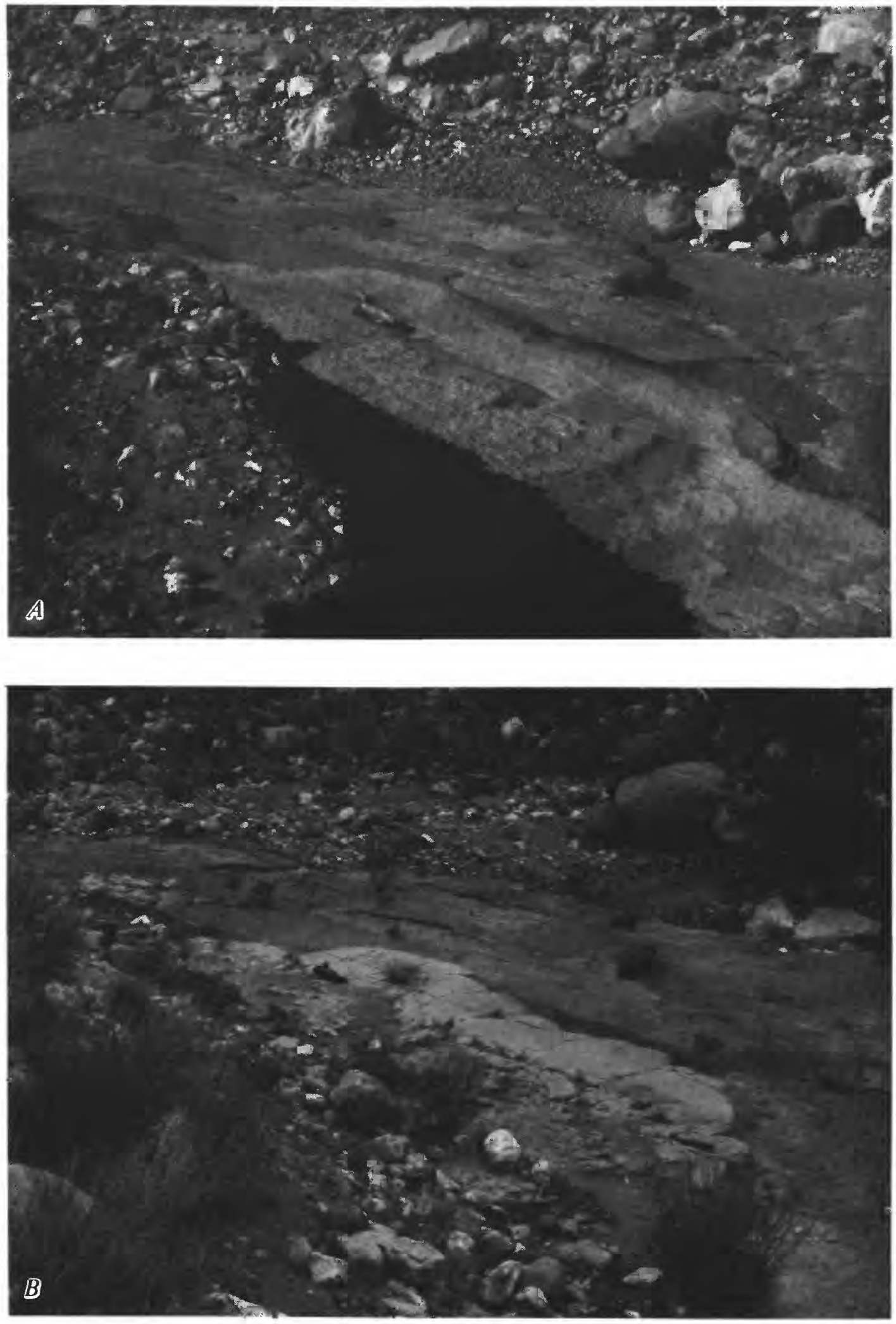

Figure 15.-Dragon Creek, 6.2 miles upstream from the Colorado River. The piece of driftwood at the left center of view $B$ (April 1986) is not the same piece as in view $A$ (February 1967). Note in view $B$ that the large rocks at the upper left and right have been moved downstream and the bank has collapsed in the foreground. Flow in the channel moves right to left. 
The debris flow of 1966 left considerable stage and sedimentologic evidence of its passage in the Crystal Creek drainage. In Tapeats Narrows (site D, fig. 13), mudlines were observed $40 \mathrm{ft}$ above the current channel. The red color of debris-flow matrix contrasted greatly with the brown soils on terraces and hillslopes. The damaged mescal pit (site A, fig. 13) was buried under 0.1 to $0.6 \mathrm{ft}$ of red matrix deposit. The site, on the outside of a slight river bend, was inundated by the superelevated debris flow, but erosion was slight. Downstream, terraces of approximately the same height were not inundated.

Debris-flow deposits and mudlines have been preserved along the $4.5 \mathrm{mi}$ of Crystal Creek below its confluence with Dragon Creek (fig. 13). The flow from Dragon Creek blocked Crystal Creek at the confluence with a 13-ft-high boulder deposit. Debris-flow deposits from Dragon Creek were found $300 \mathrm{ft}$ upstream along Crystal Creek. Downstream, the debris flow entered a steep bedrock canyon in the Vishnu Schist and left mudlines as much as $20 \mathrm{ft}$ above the current channel bed. Evidence for recessional debris flows after the main peak was preserved in the 2.5-mile-long reach upstream of the Colorado River. The heights of the recessional debris-flow deposits, which create a sawtooth appearance on the floodplain, are approximately 5 and $6 \mathrm{ft}$ below the high-water marks for the main debris-flow pulse at site G (fig. 13).

The effects of the debris flow of 1966 on Crystal Rapid are well known (Collins and Nash, 1978; Kieffer, 1985; Stevens, 1983). The debris flow almost certainly dammed the Colorado River temporarily until subsequent flows eroded through the left (south) side (Kieffer, 1985). In 1965, the width of the Colorado River at Crystal Rapid was approximately $280 \mathrm{ft}$ at a discharge of $48,000 \mathrm{ft}^{3} / \mathrm{s}$ (Bill Emmett, U.S. Geological Survey, written commun., 1986). In March 1967, the width was only $100 \mathrm{ft}$ at a discharge of about $10,000 \mathrm{ft}^{3} / \mathrm{s}$ (Cooley and others, 1977). Maps prepared by S.W. Kieffer (U.S. Geological Survey, written commun., 1986) from aerial photographs taken in 1984 indicate a width of $130 \mathrm{ft}$ at a discharge of 5,600 $\mathrm{ft}^{3} / \mathrm{s}$. A comparison of photographs of Crystal Rapid taken in 1966 and 1986 (fig. 17) documents the persisting changes. The rock garden (site $\mathrm{H}$, fig. 13), or debris bar, located below the rapid and formed from outwash from the fan at the mouth of Crystal Creek, was substantially increased as a result of the debris flow. Photographs in Collins and Nash (1978) taken at low discharge in the Colorado River show a pre-1966 debris bar at the site of the present debris bar, but aerial photographs taken in 1965 at a discharge of $45,000 \mathrm{ft}^{3} / \mathrm{s}$ reveal no obvious debris bar.

\section{DISCHARGE CALCULATIONS}

Velocities and discharges were calculated for the peak of the debris flow of 1966 from mudlines and deposits in the Crystal Creek drainage. At site C (fig. 13), a tight, nearly $180^{\circ}$ bend in Dragon Creek, an elevation difference of $11.9 \mathrm{ft}$ was measured between the high-water marks in cacti and shrubs on the inside and outside of the bend. Based on a radius of curvature of $36 \mathrm{ft}$ and width of 103 $\mathrm{ft}$, the debris flow had a mean velocity of $11.5 \mathrm{ft} / \mathrm{s}$. The discrepancy between the radius of curvature and the width may invalidate the assumption that all streamlines follow the radius of curvature (see section "Hydraulics of Debris Flows"). The channel had significantly aggraded after 1966, and cross sections necessary for a discharge calculation could not be surveyed.

Below Tapeats Narrows, a runup deposit preserved under an overhanging ledge of Tapeats Sandstone provided an opportunity to estimate the discharge for the debris flow of 1966 (site $\mathrm{E}$, fig. 13). We calculated a mean velocity of $15.9 \mathrm{ft} / \mathrm{s}$ from the runup evidence (table 7 ). One cross section with an area of $710 \mathrm{ft}^{2}$ was measured at the runup site and resulted in an estimated discharge of $11,300 \mathrm{ft}^{3} / \mathrm{s}$. The longitudinal variation in cross-sectional area was not investigated at this site, but it may have been substantial.

Photographs from Cooley and others (1977) were used to reconstruct high-water marks at site F (Cooley site number Ariz. B:16:42). The prominent superelevation

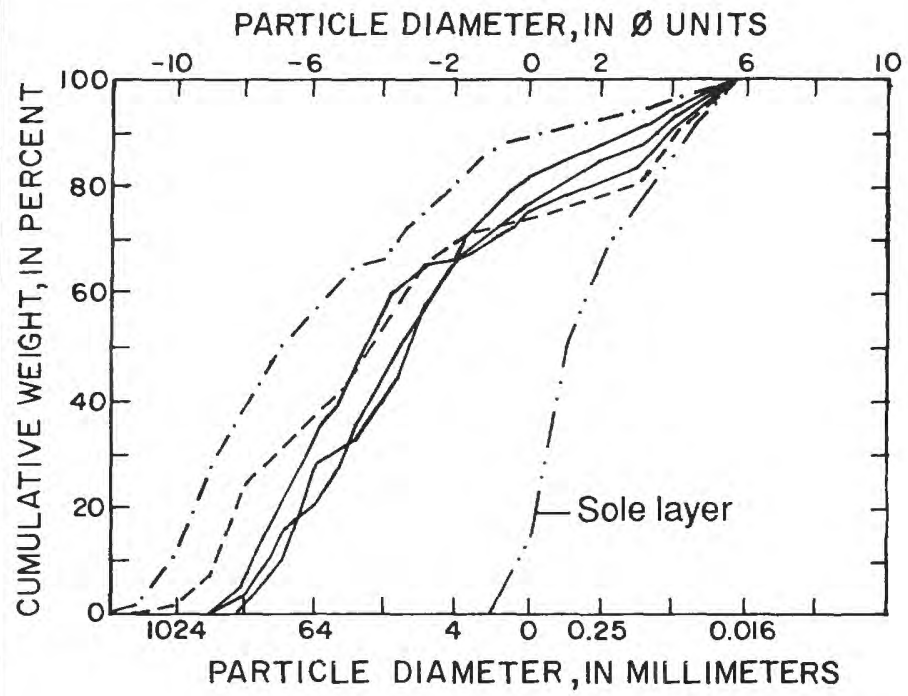

\section{EXPLANATION}

-.- COARSE-GRAINED FACIES-Site G, 0.9 mile upstream from Colorado River

- - FINER GRAINED DEPOSIT-Site G, 0.9 mile upstream from Colorado River

- DEBRIS-FLOW DEPOSITS-Confluence of Crystal and Dragon Creeks, 4.5 miles upstream from Colorado River

FIGURE 16.-Particle-size distributions of the debris flow of 1966 in the Crystal Creek drainage. See figure $\mathbf{1 3}$ for locations. 
marks (Cooley and others, 1977, fig. 16A) were relocated and surveyed. Elevation differences between terraces, mudlines, and the channel bed reported in Cooley and others (1977, fig. 36) indicated no net aggradation or deposition in the intervening 18 years. Relocation of the sites (especially Cooley and others, 1977, fig. 34C) revealed local channel widening upstream from the bend. Although the channel changed slightly between 1967 and 1986 , no evidence for post-1966 debris flows was found at this site.

We surveyed a longitudinal profile of mudlines and measured an elevation difference of $22.7 \mathrm{ft}$ between lines on the inside and outside of the bend (table 8). The longitudinal profile (fig. 18A) shows an increase in the slope of the channel bed at the start of the bend that may have affected the flow regime. The mescal pit at this site (Cooley and others, 1977) was narrowly missed by a lowerstage superelevation on an upstream bend (fig. 18A).
Mean velocity on the larger bend was calculated to be 17.7 $\mathrm{ft} / \mathrm{s}$. Surveyed cross sections indicate that the area at the highest superelevation marks is nearly three times larger than upstream and downstream areas (table 8). On the basis of an average area of upstream and downstream cross sections, we calculated a discharge of $14,000 \mathrm{ft}^{3} / \mathrm{s}$ for the 1966 debris flow, although we estimate a numerical uncertainty of between 11,900 and $15,400 \mathrm{ft}^{3} / \mathrm{s}$. The water content of the flow, reconstituted from a sample taken 0.3 mi downstream, was 24 to 26 percent by volume.

At site G, 0.9 mi upstream from the Colorado River, superelevation and runup marks were preserved on the walls of Vishnu Schist and in cacti. Superelevation evidence (fig. $18 B$ ) was used to calculate a mean velocity of $10.3 \mathrm{ft} / \mathrm{s}$ (table 9 ). However, mean velocities calculated from runup evidence at two points (fig. 18B) were 15.0 and $15.4 \mathrm{ft} / \mathrm{s}$. As noted at all other superelevation sites, the area of cross sections measured near superelevation

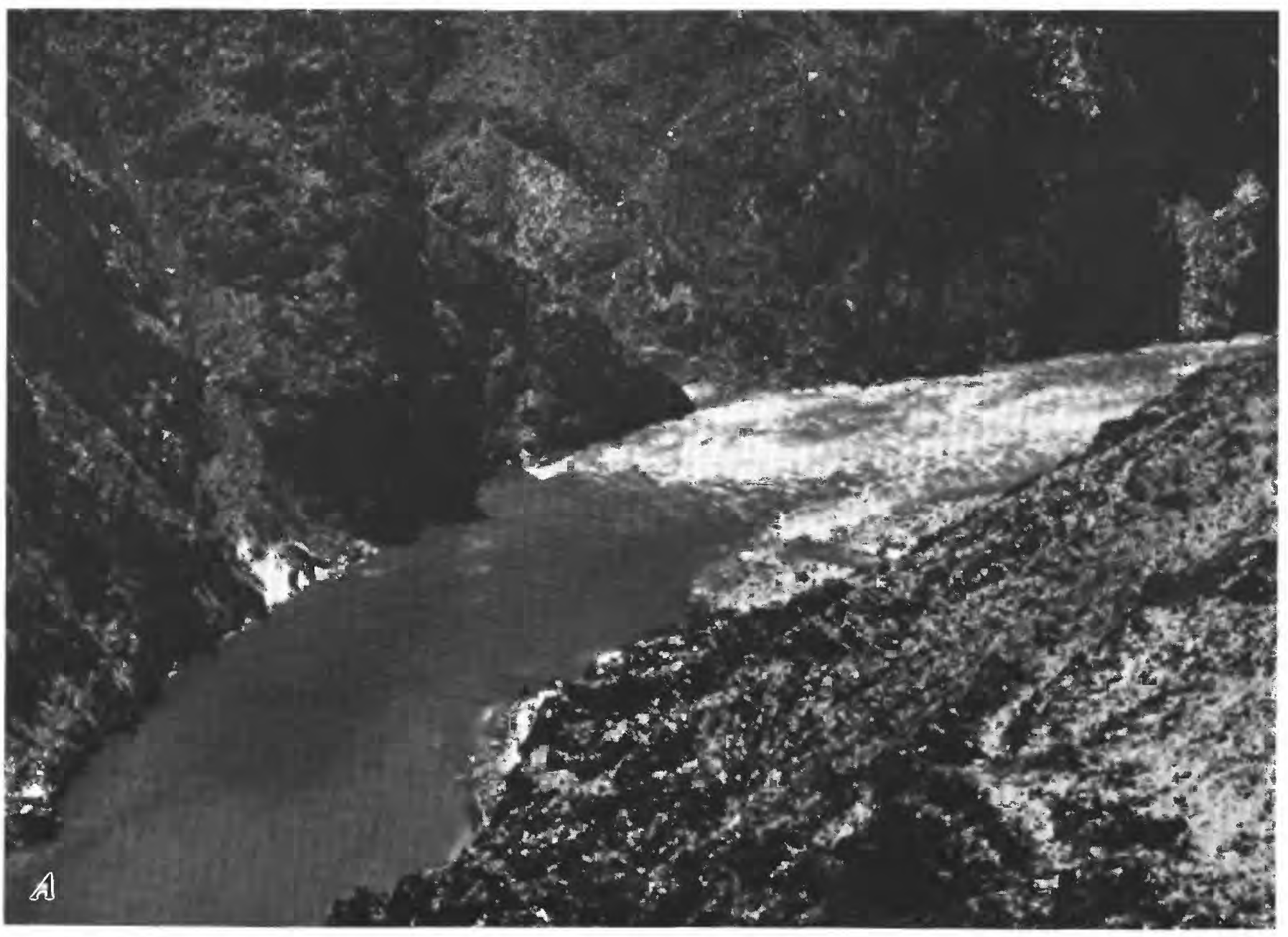

FiguRE 17.-Crystal Rapid at the mouth of Crystal Creek. The poor visual quality of view $A$ (May 1966) results from deterioration of the original color slide. Note the small debris fan and smooth tongue of water entering the rapid at right center of the river. The discharge of the Colorado River is 16,000 cubic feet per second. In view $B$ (April 1986), the tongue of the rapid has been forced to the left as a result of the debris fan deposited during the debris flow of 1966 . The discharge of the Colorado River is 28,500 cubic feet per second. 
marks were significantly larger than the areas of cross sections upstream and downstream from the marks (table 9). We estimated a discharge of between 9,200 and 13,500 $\mathrm{ft}^{3} / \mathrm{s}$ for the debris flow on the basis of the range in velocities and cross-sectional areas. The water content of the flow, reconstituted from a sample taken $0.1 \mathrm{mi}$ downstream, was 31 to 33 percent by volume.

Particle-size distributions (fig. 16) show that extremely coarse, poorly sorted sediments were transported during the debris flow of 1966 . The sediments contained 10 - to 15-percent sand and 5- to 10-percent silt and clay (fig. 16); different samples had similar particle-size distributions except in a coarse facies found $0.9 \mathrm{mi}$ above the Colorado River. Boulders $7 \mathrm{ft}$ in diameter were common in levee deposits. One boulder measured at site $\mathrm{G}$ was a rectangular block that had dimensions of $14 \times 7 \times 6 \mathrm{ft}$ and weighed an estimated 49 tons. Nine other boulders on this 0.1-mile-long levee had intermediate diameters in excess of $5 \mathrm{ft}$. Similar-sized boulders are found in the debris fan at the mouth of Crystal Creek (S.W. Kieffer, U.S. Geological Survey, written commun., 1986).

\section{SIMILARITIES AND CONTRASTS AMONG THE DRAINAGES}

The debris flows of 1966 in the Crystal Creek and LavaChuar Creek drainages and the debris flow of 1984 in the Monument Creek drainage have similar characteristics. The debris flows all were initiated by slope failures in the Hermit Shale and the Esplanade Sandstone during an intense storm event. All three debris flows transported a poorly sorted mixture of clay- to boulder-size particles in slurries. Water contents ranged from 23 to 33 percent during the initial peak. The flows were followed by recessional debris and (or) hyperconcentrated flows that deposited distinctive sawtooth-shaped levees on the flood plain. Peaks of the debris flows reached the Colorado River, and two of the three debris flows caused significant constrictions of the Colorado River at the tributary mouth.

Our limited data suggest an important mechanism of channel adjustment following debris flows that reached the Colorado River. As illustrated by the stratigraphy in Tapeats Narrows of Dragon Creek (fig. 14), not all debris

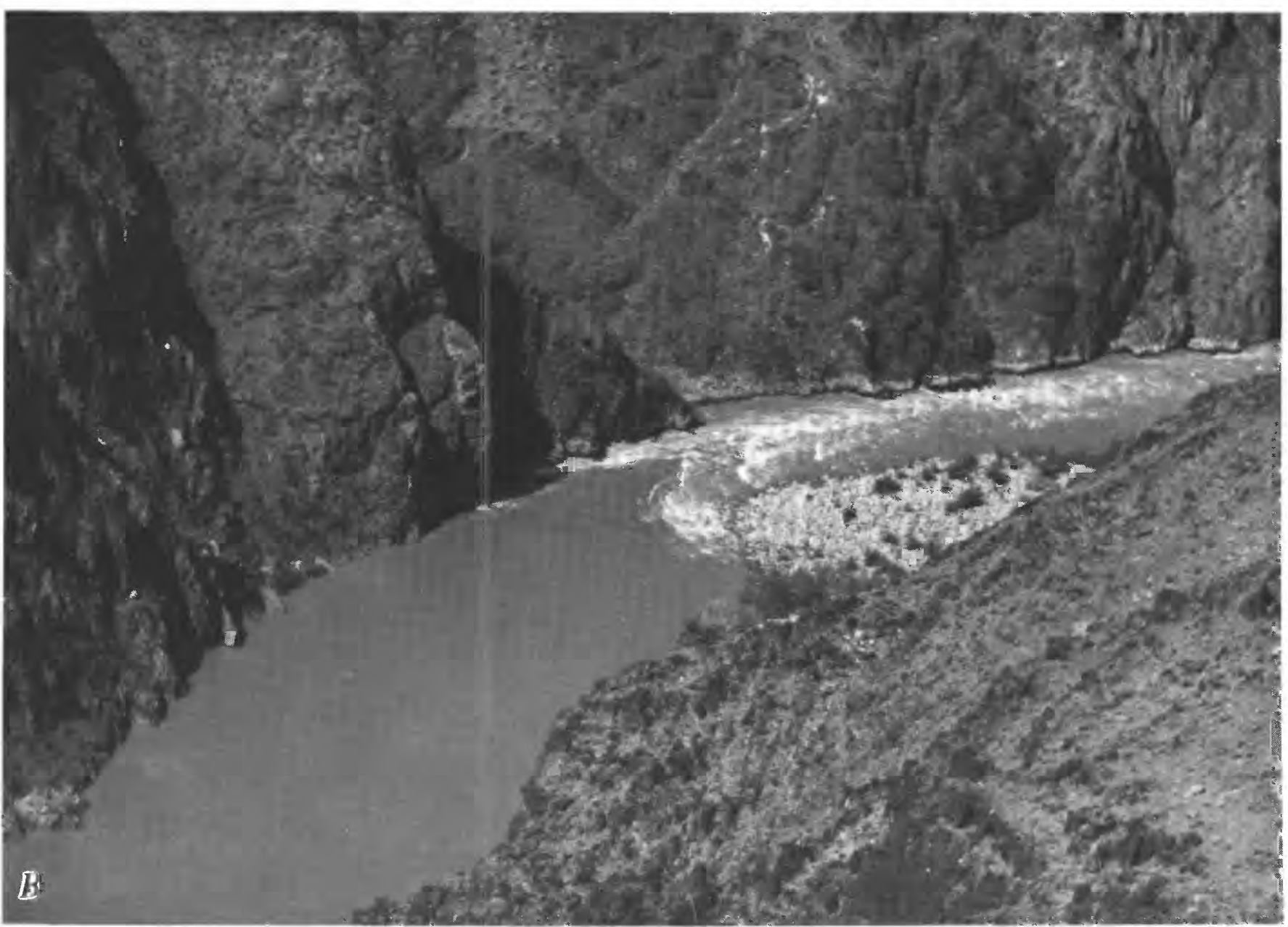

Figure 17.-Continued. 
flows reach the Colorado River. Small debris flows fill the headwater channels with sediments after they stop flowing and raise the bed elevation by tens of feet. Subsequent flows of larger volume may be able to erode through this stored sediment and incorporate it into the moving fluid. Smaller debris flows may prime the channel for larger debris flows that have sufficient volume of sediments to reach the Colorado River.

We determined a significant problem with the measurement of the effective flow area of debris flows at all sites where discharges were estimated. The cross-sectional areas at the superelevation marks are 1.3 to 3.6 times larger than upstream or downstream areas (table 10). Discharges calculated using the areas at superelevation marks, therefore, are 1.3 to 3.6 times larger than those calculated using the upstream and downstream areas (table 10). If the cross sections at the superelevation marks are used, continuity of flow (equation 4) implies substantially higher velocities on the approaches and exits to the bends. Using site F in the Lava-Chuar Creek drainage as an example, the exit velocity would be $43 \mathrm{ft} / \mathrm{s}$ if the cross-sectional area at the superelevation marks were fully effective during the peak of the debris flow. The velocity would have increased $31 \mathrm{ft} / \mathrm{s}$ in $250 \mathrm{ft}$ with no significant slope change under these conditions.

Discharges were estimated from upstream and (or) downstream cross-sectional areas and assumed that the velocity was not significantly changed through the bend
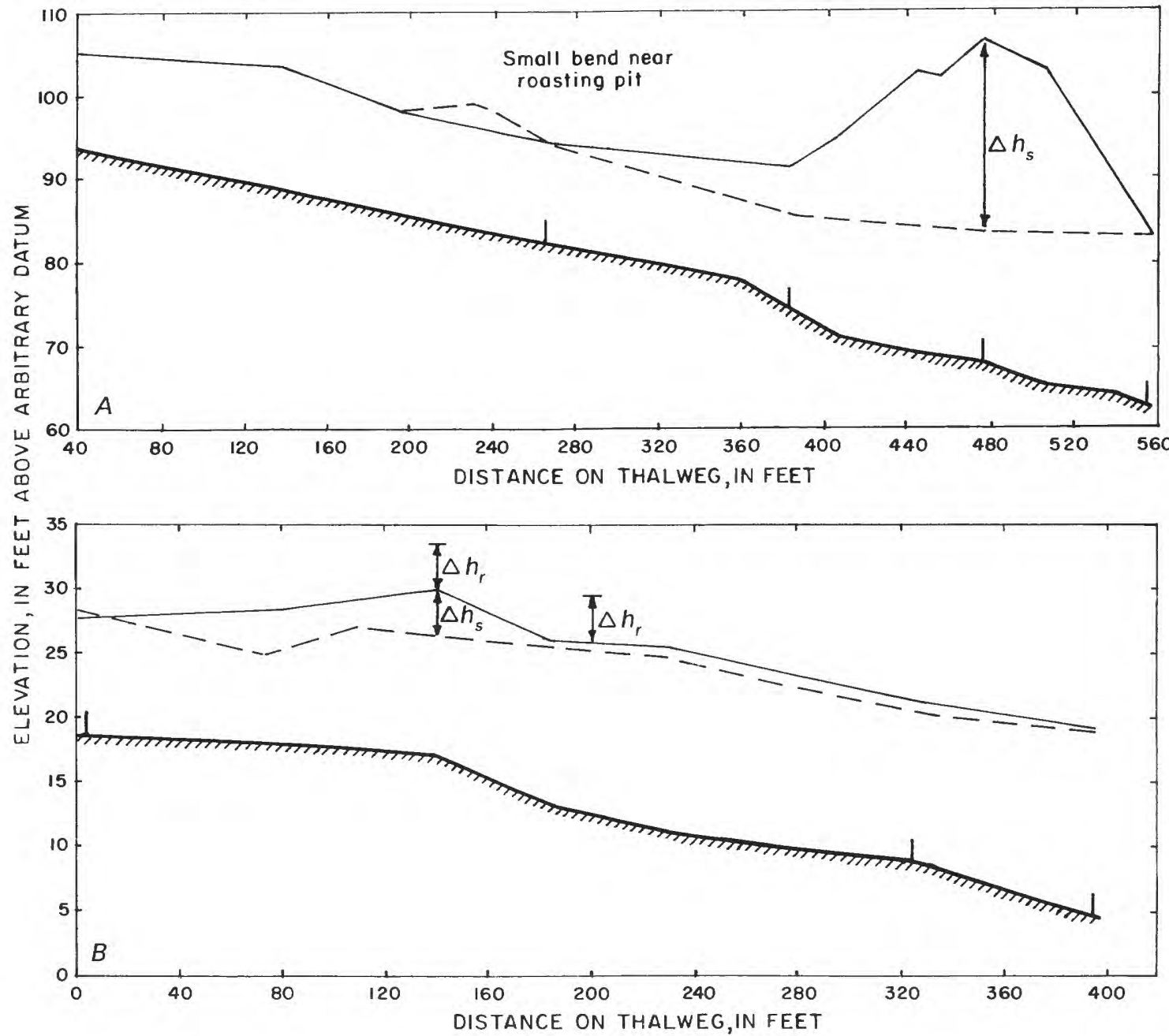

EXPLANATION

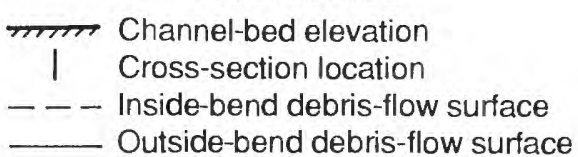

FIGURE 18.-Longitudinal profiles for indirect-discharge sites in the Crystal Creek drainage. $A$, Site F, 4.8 miles upstream from the Colorado River. $B$, Site G, 0.9 mile upstream from the Colorado River. 
by energy losses. Several hydraulic properties of debris flows can be used to support the latter assumption. Because of their cohesive nature, debris flows may have large ineffective flow areas consisting of static sediment on the margins of channel bends. Superelevation formulae are used to calculate not only a mean velocity across a cross section but also a mean velocity around part of the bend. For example, Apmann (1973) uses the curvature angle of the bend in his formula, implying that superelevation is a function of both longitudinal and mean crosssectional velocity. Finally, the low turbulence and high momentum of debris flows probably reduces longitudinal variations in velocity. Calculation of velocities of debris flows using superelevation evidence appears to involve a considerable error that could not be estimated in this study.

The three drainages that we studied had different frequencies for debris flows reaching the Colorado River. We could not estimate a true magnitude-frequency relation because we estimated discharges only for a single flow in each drainage. Relative stages of successive debris flows were determined; however, channel changes between events may have changed the stage-discharge relation for the channel. The Lava-Chuar Creek drainage had the most frequent debris flows that reached the Colorado River with an average of one event every 20 to 30 years. Monument Creek had at least two debris flows this century, and they both occurred within 25 years. Crystal Creek had only one debris flow reaching the Colorado River this century and averages a minimum of one debris flow every 50 years that reaches the Colorado River.

The size of transported boulders varied considerably among the drainages. The largest boulder transported by the debris flow of 1966 in the Lava-Chuar Creek drainage weighed an estimated 9 tons. Boulders that were transported in the Monument and Crystal Creek drainages weighed an estimated 37 and 49 tons, respectively. In all drainages, larger boulders may have been transported into the Colorado River. The sand content of the flows ranged from 10 to 40 percent and represents a potentially significant source for beach sands along the Colorado River.

\section{FLUVIAL EVENTS IN OTHER DRAINAGES}

As previously stated, debris flows are common phenomena in Grand Canyon National Park. Individual drainages such as Lava-Chuar Creek may average 20 to 30 years between debris flows that reach the Colorado River; in the park as a whole, however, such flows occur much more frequently. We gathered historical information and analyzed aerial photography from 1965, 1973, and 1984 to compile a list of historical fluvial events from ungaged tributaries that have affected their debris fans at the Colorado River (table 11). We also list known historic debris flows and floods in table 11 . The list is not all inclusive, because more than one flow could have induced the changes and not all floods were debris flows. However, the list provides a perspective on the frequency of fluvial events, many of which were debris flows, between 1965 and 1986.

In the historical record, the summer of 1983 probably was the most significant year for fluvial events from ungaged tributaries. Rainfall was above average during July and August. On July 25, Grand Canyon, Bright Angel Ranger Station, and Phantom Ranch had 3.14, 2.02, and 1.85 in of rainfall, respectively. No intensity data are available for this storm; however, the daily totals suggest pervasive storms in the Grand Canyon on July 25. Almost all the drainages between Colorado River mile 42 and mile 77 had flash floods during the summer of 1983 (table 11), possibly during the storm on July 25 . Sediment-sampling data from the gaging station on the Colorado River at Phantom Ranch shows small peaks in sediment during July and August 1983, which may be attributable to these floods.

A winter storm in December 1966 caused widespread flooding within Grand Canyon National Park (Cooley and others, 1977). A storm originating in the north Pacific Ocean traveled slowly over northern Arizona and southern Utah between December 3 and 6 (Butler and Mundorff, 1970). Floods on the Virgin River in southern Utah exceeded the 100-year event (Butler and Mundorff, 1970), suggesting that this type of storm is rare. Precipitation totaling 11 to 14 in. fell on the North Rim (Cooley and others, 1977), triggering floods in Bright Angel Creek and several other drainages with headwaters on the Kaibab Plateau. The debris flows in the Lava-Chuar and Crystal Creek drainages (see "Debris Flows in Three Tributaries of the Colorado River") and ten other debris flows not reaching the Colorado River were initiated during this storm (Cooley and others, 1977).

In July 1984, a debris flow with a stage of greater than $7 \mathrm{ft}$ and width of $200 \mathrm{ft}$ struck two 20 -ton trucks stalled in the channel of Diamond Creek about 0.5 mi upstream from the Colorado River (Mike Walker, boatman, O.A.R.s, Modesto, California, oral commun., 1986). The trucks were carried into the river and later were found more than $1,000 \mathrm{ft}$ downstream on the opposite bank. Boulders 4 to $5 \mathrm{ft}$ in diameter were transported by the debris flow, which remained at uncrossable levels for $6.5 \mathrm{hrs}$. The debris flow reportedly caused 30-foot-high spray upon impact with the Colorado River and greatly enlarged the debris fan.

This brief history indicates that several storm types may initiate fluvial events, which include debris flows, in the Grand Canyon. Summer thunderstorms appear to be the most common type of storm that initiates debris flows. These storms generally are localized in one or two adja- 
cent drainages and can be considered as random in time. Intense precipitation resulting from winter frontal storms also may initiate debris flows; however, this type of storm generally is rare.

\section{FACTORS RESPONSIBLE FOR DEBRIS FLOWS}

The bedrock geology of Grand Canyon National Park controls the location of the initiation sites for debris flows in tributaries of the Colorado River. The Grand Canyon is noted for spectacular cliffs of sedimentary rocks, and the combination of stratified rocks with different strength properties and high relief leads to a high potential for slope failures (Rogers and Pyles, 1979). In addition, fault planes control the location of drainages in Grand Canyon (Dolan and others, 1978; Potochnik and Reynolds, 1986), and the resultant shear zones provide abundant loose and poorly sorted material for debris-flow initiation. Abundant talus accumulates locally beneath cliff faces, providing a source for debris mobilization during intense storm events. The Grand Canyon is, in fact, an ideal location for debris flows.

The most common cause for debris flows is slope failures in the Hermit Shale and Supai Group throughout the Grand Canyon. In the only systematic mapping of slope failures, Cooley and others (1977) mapped 93 slope failures that occurred during the storm of 1966 . Seventy percent were from the Hermit Shale and Supai Group; 19 percent from the Kaibab Limestone and underlying Toroweap Formation, or Coconino Sandstone; and 11 percent from the Muav Limestone. Most of these failures resulted in local debris flows, and failures in the Hermit Shale and the Supai Group initiated debris flows in the Lava-Chuar and Crystal Creek drainages that reached the Colorado River.

The composition and chemistry of the Hermit Shale and Esplanade Sandstone have the potential to generate debris flows. The Esplanade Sandstone at the top of the Supai Group consists of alternating layers of sandstone, siltstone, and mudstone and forms a morphologically distinct series of basal slope, cliff, and upper slope (McKee, 1982). This formation is of continental origin, which contrasts with the marine origin of the other three formations of the Supai Group. Swelling clays, notably smectites and montmorillonites, are abundant in these rocks (McKee, 1982) and cause rapid weathering of the cliffs into potentially mobile talus. Both the Hermit Shale and Esplanade Sandstone contain dispersive clays, which disintegrate into colloidal suspension when water is added (J.D. Rogers, Rogers/Pacific Consultants, Lafayette, California, oral commun., 1986). When these rocks are located on top of cliffs of Redwall Limestone, catastrophic slope failures are possible as the rocks weather.

The combination of alternating rock types, dispersive clays, and the high relief in the drainage basins make canyons with exposures of Hermit Shale and Esplanade Sandstone particularly susceptible to debris flows. The proximity of these rocks to the Colorado River may explain some of the longitudinal spacing of rapids. The Roaring Twenties (fig. 1) are a series of closely spaced, moderate-size rapids that occur where the Hermit Shale and Supai Group are first elevated above the river. In contrast, few moderate to large rapids occur between Kanab Creek and Prospect Creek (fig. 1), possibly because the Hermit Shale and most of the Esplanade Sandstone have been stripped from the nearby cliffs.

Several drainages exemplify other sources of sediments for debris-flow mobilization in Grand Canyon National Park. Red Canyon (fig. 1) has formed at the intersection of several major faults, and two large landslide deposits have been mapped in its headwaters (Huntoon and others, 1986). Hance Rapid is formed where a debris fan from Red Canyon forces the Colorado River against a bedrock wall. Large boulders in the channel cause severe navigational difficulties at low water (Stevens, 1983). Debris flows from Red Canyon have occurred relatively frequently in geologic time as indicated by the large debris fan, multiple levees, and exposed debris-flow stratigraphy. The large landslides and shear zones in the headwaters are the probable source of sediments for the debris flows.

Lava Falls Rapid, generally regarded as the most difficult to navigate on the Colorado River (Collins and Nash, 1978), is formed by debris transported from Prospect Creek (fig. 1) and not by outcrops of resistant rocks (Leopold, 1969). Four large basalt boulders form the infamous Ledge Hole in the center of the rapid. The fan at the mouth of Prospect Creek consists of four inset terraces, each of which is composed of multiple debris-flow deposits. The source of sediments for debris flows is the loose basalt talus in the shear zone of the Toroweap fault about $1 \mathrm{mi}$ from the Colorado River (Huntoon and others, 1981). Discharges in Prospect Creek cascade over a 1,200-foot cliff and initiate slope failures in the loose talus.

The occurrence of debris flows is not controlled by an obvious basin morphometric factor in Grand Canyon National Park. Similar adjacent basins appear to have completely different histories of debris flows. For example, Monument Creek has had two debris flows that reached the Colorado River in 25 years and Hermit Creek, slightly larger in size and abutting Monument Creek on the west, has had no obvious debris flows that reached the river during the same period. Although the storm of December 1966 initiated a debris flow in the Crystal Creek drainage, the adjacent and larger Shinumo Creek drainage had only small debris flows in its headwaters, and only streamflow reached the Colorado River (Cooley and others, 1977). Clearly, debris flows that reach the Colorado River are a random occurrence controlled by the combination of accumulation rates of sediment available for transport and intense storm events. 
An attempt was made to explain the navigational difficulty and water-surface fall through 67 rapids of the Colorado River on the basis of contributing drainage areas of tributaries (table 12). Although navigational difficulty and water-surface fall through a rapid are not good predictors of the frequency or size of debris flows from the tributaries, they are the only known characteristics available for the entire Colorado River corridor. Drainagebasin area is the hydrologic variable most commonly used to assess regional flood and sediment-transport potential. All rapids with a maximum rating greater than 4 (Stevens, 1983) are included with the exception of Lower Lava Rapid, which is controlled by outwash debris from Lava Falls Rapid and Prospect Creek, and Nixon Rock Rapid, which is controlled by rockfalls. Selected rapids with a maximum rating of 4 or less were also included (table 12). With the exception of the Paria and Little Colorado Rivers, all drainages included had obvious debris-flow deposits at the Colorado River.

Drainage areas of contributing tributaries do not explain either water-surface fall or navigational difficulty of rapids on the Colorado River (fig. 19). Local channel factors also cannot explain these variables because rapids with similar navigational difficulties have different watersurface falls and constriction ratios (S.W. Kieffer, U.S. Geological Survey, written commun., 1986). Local channel conditions such as bedrock spurs and confining-wall geometry may exacerbate a rapid. We attribute the noncorrelation of drainage area and rapid difficulty to the overwhelming control of rapid difficulty by local factors in each contributing drainage, particularly the size of debris-flow-transported boulders, the history of debris flows, and local channel conditions.

\section{HYDROLOGIC EFFECTS OF DEBRIS FLOWS ON THE COLORADO RIVER}

The magnitude and frequency of debris flows control the hydraulics of the Colorado River in Grand Canyon National Park. Debris flows from small tributaries aggrade fans which typically force the river against the opposite wall of the canyon (fig. 20). In some cases, debris fans from tributaries on opposite sites of the river, such as the Lava-Chuar Creek drainage and Palisades Creek, constrict the Colorado River without a directional change. Debris flows deposit very large boulders in the river that cannot be moved by ordinary discharges. Therefore, rapids tend to be maintained as hydraulic controls on the river until the boulders can be moved by rare, large discharges (Graf, 1979). The ability of small drainages such as Monument Creek to control the hydraulics of one of the largest rivers in the United States is of great hydrologic significance.

The combination of a debris fan and the increased velocity of flow in the rapid creates flow-separation zones conducive to the formation of beaches (Schmidt and Graf, 1988). Constriction ratios at debris fans range from 0.3 to 0.7 (Kieffer, 1985), and separation zones (and consequently beaches) form upstream and downstream from rapids. The combination of sudden channel expansion and rapid deceleration of flow below rapids induces the recirculating-eddy systems common in Grand Canyon National Park (Schmidt and Graf, 1988). Debris-flow transport of boulders onto the fan surfaces is the key process in creating the system of flow separations on the Colorado River.

Control of local channel hydraulics extends beyond the rapid and debris-fan system. Prominent debris bars, referred to as islands or rock gardens, are formed downstream from the rapid by reworking of the debris fans after a debris flow. Commonly on the opposite side of the river from the tributary, these bars generally are composed of well-sorted, imbricated cobbles and boulders mixed with sand. At Crystal Creek, the rock garden was
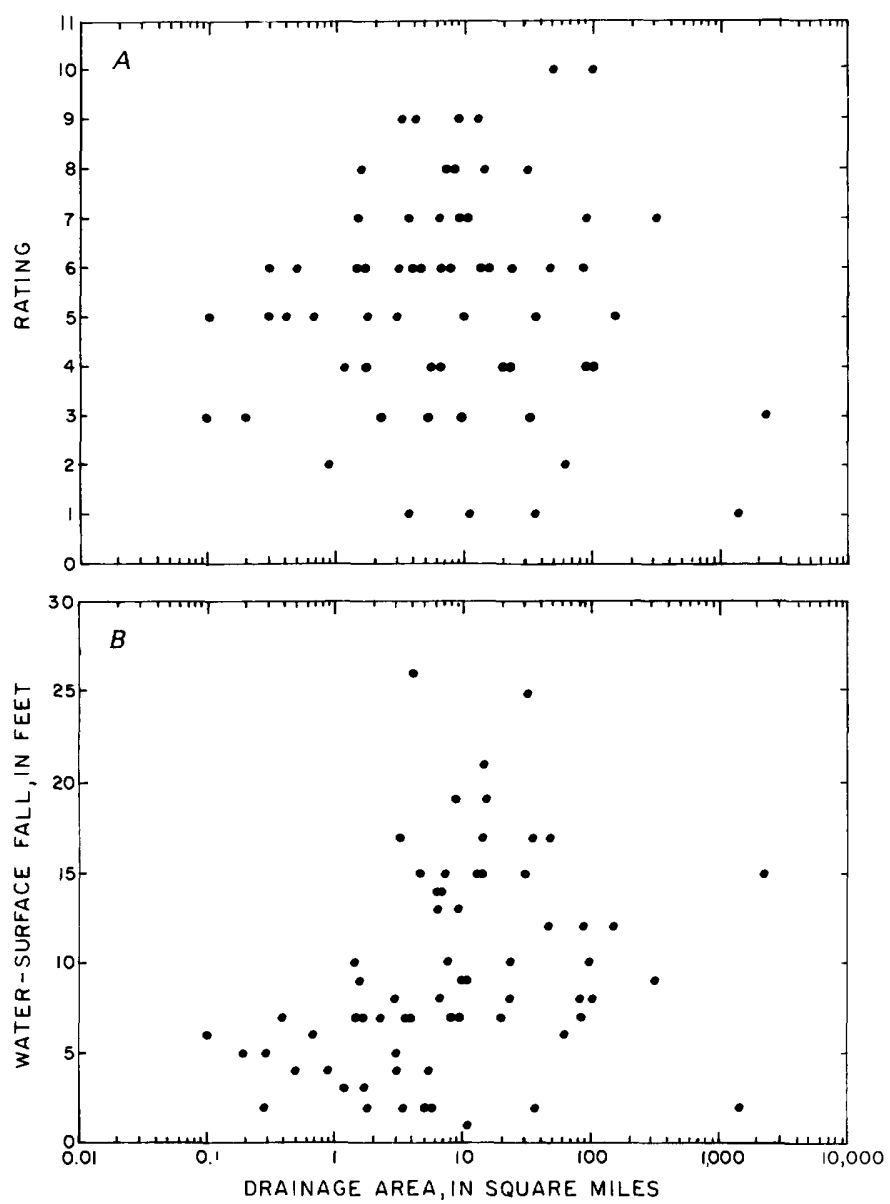

FIGURE 19.-Relation of characteristics of rapids and the contributing drainage area of the tributaries. $A$, Using the "rapid rating" (scale of 1 to 10; Stevens, 1983) for a discharge of 10,000 cubic feet per second in the Colorado River. $B$, Using the water-surface fall surveyed in 1921 and adjusted to 10,000 cubic feet per second. This fall may have significantly changed as a result of historic debris flows, especially at Crystal Rapid. 
greatly enlarged after the debris flow of 1966 and contains boulders that are unusually large for a debris bar. At Monument Creek, the island enlarged slightly after the 1984 debris flow. An island in the Colorado River at river mile 66 (Stevens, 1983) appears to be maintained by periodic debris flows from the Lava-Chuar Creek drainage and Palisades Creek. Debris bars, particularly in the form of islands, provide a control on the longitudinal extent of eddy systems. Large debris bars induce secondary riffles or rapids, such as Lower Lava Rapid at river mile 179.8, that may be additional navigational hazards or form secondary flow-separation zones.

Debris flows from tributaries have important influences on sediment transport in the Colorado River. Although the debris flows occur infrequently, they are the source of large volumes of sand that enter at discrete points along the river. Debris flows transport boulders into the Colorado River that create the hydraulic controls that are prominent in the longitudinal profile of the river (Howard and Dolan, 1981). Debris fans and bars control the formation and longitudinal extent of separation zones needed to trap sand. A thorough understanding of the magnitude and frequency of debris flows is of paramount importance

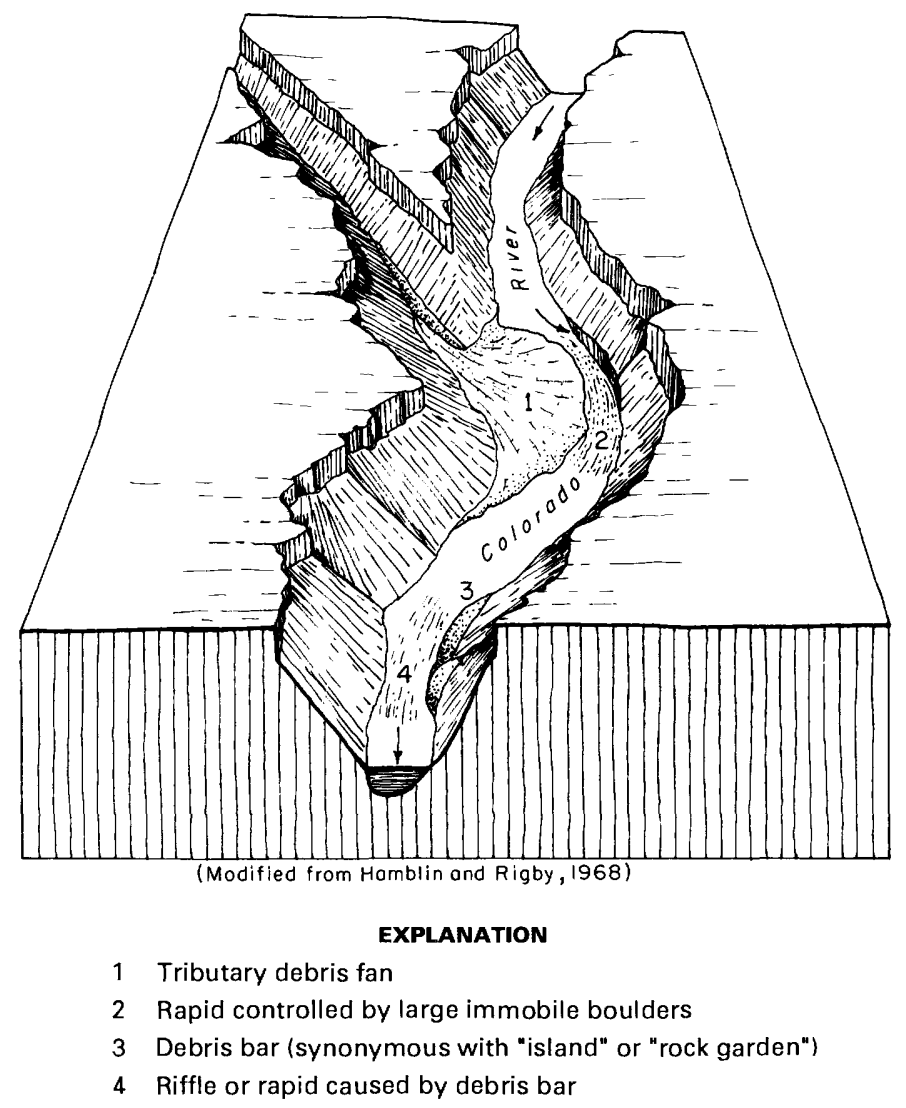

FIGURE 20.-Geomorphic features of a typical rapid controlled by debris flows on the Colorado River. to understanding and long-term estimates of sediment transport in the Colorado River in Grand Canyon National Park.

\section{SUMMARY}

Sediment transported from small drainages is a potentially large source of sand for beaches on the Colorado River in Grand Canyon National Park. Previous flood reports (Cooley and others, 1977) and recent mapping of alluvial deposits in tributary canyons during this project indicate that debris flows are a major process of sediment transport in small drainages in Grand Canyon National Park. Debris flows are common in arid and semiarid regions, but their importance in supplying sediment to the Colorado River has not been previously recognized.

We observed debris-flow deposits in all 36 tributaries of the Colorado River that were examined during this study. Twenty-one of the 36 tributaries have evidence for debris flows within the last 25 years. We selected three tributaries for more detailed study on the basis of previous reports of debris flows. The tributaries studied in detail are the Lava-Chuar Creek drainage at Colorado River mile 65.5, the Monument Creek drainage at river mile 93.5, and the Crystal Creek drainage at river mile 98.2. Evidence for at least five prehistoric debris flows and three historic debris flows is preserved in the Lava-Chuar Creek drainage. Historic debris flows occurred between 1973 and 1984, in December 1966, and between 1916 and 1966. Debris flows have reached the Colorado on the average every 20 to 30 years since 1916 and every 190 years over the last 1,500 years. Debris flows may reach the Colorado River more frequently because not all prehistoric debris flows may have overtopped the terraces to leave depositional evidence.

The debris flow of 1966 in the Lava-Chuar Creek drainage had a velocity of $12 \mathrm{ft} / \mathrm{s}$ and a discharge of about 4,000 $\mathrm{ft}^{3} / \mathrm{s}$ near the Colorado River. The debris flow began at slope failures in the Hermit Shale and Supai Group and traveled $6.5 \mathrm{mi}$ to the Colorado River. The water content of the flow was estimated at 22.5 percent and yielded sediment and water discharges of 3,100 and $900 \mathrm{ft}^{3} / \mathrm{s}$, respectively. The debris flow had 30 to 35 percent sand and carried boulders 1 to $2 \mathrm{ft}$ in diameter. The largest boulder measured that was transported during the 1966 debris flow weighed an estimated 9 tons.

Two debris flows have occurred in the last 25 years in the Monument Creek drainage. A storm on July 27, 1984, initiated an avalanche and subsequent debris flow that reached the Colorado River. Scanty evidence suggests an earlier debris flow that occurred in the early 1960's. Older debris-flow deposits were radiometrically dated at about A.D. 1780 , but lack of correlation with downstream deposits precluded any use of this date for determining frequencies of events. 
The debris flow of 1984 in Monument Creek began as an avalanche from the Esplanade Sandstone of the Supai Group 2,000 ft above the channel. A 20-foot high avalanche deposit still dammed the channel in 1986. The debris flow traveled $2.8 \mathrm{mi}$ to the Colorado River at a velocity of 11 to $13 \mathrm{ft} / \mathrm{s}$ and a peak discharge of about $3,800 \mathrm{ft}^{3} / \mathrm{s}$. The water content of the flow ranged from 27 to 34 percent and the flow was composed of 30 to 40 percent sand. One boulder transported during the flow weighed an estimated 37 tons.

The debris flow of 1984 created a new fan surface at the Colorado River that significantly constricted Granite Rapid. We estimated the volume of sediment transported onto the fan and into the river on the basis of hypothesized scenarios of post-debris-flow fan geometry. The most likely volume of sediment transported onto the fan and into the river is $300,000 \mathrm{ft}^{3}$. The absence of particles less than $16 \mathrm{~mm}$ in diameter on the debris fan in $1986 \mathrm{sug}$ gests that all finer particles including sand were quickly transported into the Colorado River. By assuming an average sand content of 35 percent, the estimated volume of sand that entered the river is $84,000 \mathrm{ft}^{3}$ with a range of 56,000 to $150,000 \mathrm{ft}^{3}$ for the scenarios that were considered. From the volume of sediment moved and the discharge estimated upstream, we estimated that the fan was created during the first pulse of the debris flow in 1 to 3 minutes.

The Crystal Creek drainage has averaged a minimum of one debris flow that reached the Colorado River every 50 years. A large debris flow in 1966 has been the only debris flow to reach the Colorado River in this century. Small debris flows, on reaching the Colorado River, have significantly aggraded the channel in the past, possibly storing sediments available to larger debris flows capable of reaching the river.

The debris flow of 1966 in the Crystal Creek drainage began at 11 slope failures in the Hermit Shale and Supai Group and traveled $13 \mathrm{mi}$ to the Colorado River. The calculated flow velocity ranged from 10 to $18 \mathrm{ft} / \mathrm{s}$, and the discharge ranged from 9,200 to $14,000 \mathrm{ft}^{3} / \mathrm{s}$. The water content of the flow ranged from 24 to 33 percent, and the sediments had a sand content of 10 to 15 percent. One boulder transported by the debris flow weighed an estimated 49 tons, and boulders with diameters in excess of $5 \mathrm{ft}$ were commonly transported. Upon reaching the Colorado River, the debris flow created a new fan surface that significantly constricted the Colorado River.

The debris flows studied had similarities that indicate the cause and nature of debris flows in Grand Canyon National Park. All three debris flows were initiated at slope failures in the Hermit Shale and Supai Group, especially the Esplanade Sandstone. All debris flows transported a poorly sorted mixture of clay- to bouldersized particles with water contents ranging from 23 to
33 percent by volume. The largest boulders transported ranged from 9 tons in the Lava-Chuar Creek drainage to 37 and 47 tons in the Monument Creek and Crystal Creek drainages, respectively. Two of the three debris flows significantly constricted the Colorado River at the tributary mouths. The frequency of debris flows that reach the Colorado River is tentative, but the available data suggest one flow reached the Colorado River every 20 to 50 years in these drainages. A compilation of the scanty historical information on flow events from Grand Canyon tributaries, however, indicates that debris flows occur more frequently throughout the park.

The bedrock geology of Grand Canyon National Park provides an ideal location for the initiation of debris flows. The high relief combined with differential strength properties of the rocks leads to a high potential for slope failures. The most common source of mobilized sediments for debris flows are the Hermit Shale and Esplanade Sandstone of the Supai Group. Other sources include the Kaibab Limestone, Toroweap Formation, and Coconino Sandstone; Muav Limestone and Bright Angel Shale; and Quaternary basalts in the western Grand Canyon. Dispersive and swelling clays in some of these formations aid in the initiation of debris flows.

The magnitude and frequency of debris flows control the hydraulics of the Colorado River in Grand Canyon National Park. Debris flows from the small tributaries aggrade fans that typically force the river against the opposite wall of the canyon. The ability of small drainages such as Monument Creek to form hydraulic controls (rapids) on one of the largest rivers in the United States is of great hydrologic significance. The debris fans also cause flow separation zones conducive to deposition and storage of sand on beaches, and reworking of debris fans by Colorado River discharges creates secondary riffles or rapids. Debris flows are the source of large volumes of sand entering the river at discrete points, although the debris flows occur infrequently. A thorough understanding of the magnitude and frequency of debris flows is of paramount importance to any understanding or long-term estimates of sediment transport in the Colorado River in Grand Canyon National Park.

\section{REFERENCES GITED}

Apmann, R.P., 1973, Estimating discharge from superelevation in bends: American Society of Civil Engineers, Journal of the Hydraulics Division, v. 99 , p. $65-79$.

Beverage, J.P., and Culbertson, J.K., 1964, Hyperconcentrations of suspended sediment: American Society of Civil Engineers, Journal of the Hydraulics Division, v. 90, p. 117-126.

Blackwelder, Eliot, 1928, Mudflow as a geologic agent in semiarid mountains: Geological Society of America Bulletin, v. 39, p. 465-494.

Butler, Elmer, and Mundorff, J.C., 1970, Floods of December 1966 in southwestern Utah: U.S. Geological Survey Water-Supply Paper 1870-A, $40 \mathrm{p}$. 
Chen, Cheng-lung, 1985, Hydraulic concepts in debris flow simulations, in Bowles, D.S., editor, Delineation of landslide, flash flood, and debris flow hazards in Utah: Logan, Utah, Utah Water Research Laboratory, General Series, UWRL/G-85/03, p. 236-259.

Chow, V.T., 1959, Open-channel hydraulics: New York, McGraw-Hill, $680 \mathrm{p}$.

Collins, R.O., and Nash, R., 1978, The big drops: San Francisco, California, Sierra Club Books, 215 p.

Cooley, M.E., Aldridge, B.N., and Euler, R.C., 1977, Effects of the catastrophic flood of December, 1966, North Rim area, eastern Grand Canyon, Arizona: U.S. Geological Survey Professional Paper $980,43 \mathrm{p}$.

Costa, J.E., 1984, Physical geomorphology of debris flows, in Costa, J.E., and Fleisher, P.J., editors, Developments and applications of geomorphology: Berlin, Springer-Verlag Publishing, p. 268-317.

Costa, J.E., and Jarrett, R.D., 1981, Debris flows in small mountain stream channels of Colorado and their hydrologic implications: Bulletin of the Association of Engineering Geologists, v. 18, p. 309-322.

Dolan, Robert, Howard, Alan, and Trimble, David, 1978, Structural control of the rapids and pools of the Colorado River in the Grand Canyon: Science, v. 202, p. 629-631.

Enos, Paul, 1977, Flow regimes in debris flow: Sedimentology, v. 24, p. 133-142.

Fisher, R.V., 1983, Flow transformations in sediment gravity flows: Geology, v. 11, p. 273-274.

Gallino, G.L., and Pierson, T.C., 1985, Polallie Creek debris flow and subsequent dam-break flood of 1980, East Fork Hood River basin, Oregon: U.S. Geological Survey Water-Supply Paper 2273, 22 p.

Graf, W.L., 1979, Rapids in canyon rivers: Journal of Geology, v. 87, p. $533-551$.

Hamblin, W.K., and Rigby, J.K., 1968, Guidebook to the Colorado River, Part 1-Lees Ferry to Phantom Ranch in Grand Canyon National Park: Provo, Utah, Brigham Young University Geology Studies, v. 15, part 5, $84 \mathrm{p}$.

Hooke, R.L., 1967, Processes on arid-region alluvial fans: Journal of Geology, v. 75, p. $438-460$.

Howard, Alan, and Dolan, Robert, 1981, Geomorphology of the Colorado River in Grand Canyon: Journal of Geology, v. 89, p. 269-297.

Hungr, O., Morgan, G.C., and Kellerhals, Rolf, 1984, Quantitative analysis of debris torrent hazards for design of remedial measures: Canadian Geotechnical Journal, v. 21, p. 663-677.

Huntoon, P.W., Billingsley, G.H., Jr., and Clark, M.D., 1981, Geologic map of the Hurricane Fault Zone and vicinity, western Grand Canyon, Arizona: Flagstaff, Arizona, Grand Canyon Natural History Association map, scale 1:48,000, 1 sheet.

Huntoon, P.W., Billingsley, G.H., Jr., Breed, W.J., Sears, J.W., Ford, T.D., Clark, M.D., Babcock, R.S., and Brown, E.H., 1986, Geologic map of the eastern part of the Grand Canyon National Park, Arizona: Flagstaff, Arizona, Museum of Northern Arizona Special Publication map, 1 sheet, scale 1:62,500.

Hupp, C.R., 1984, Dendrogeomorphic evidence of debris flow frequency and magnitude at Mount Shasta, California: Environmental Geology and Water Science, v. 6, p. 121-128.

Johnson, A.M., and Rodine, J.R., 1984, Debris flow, in Brunsden, D., and Prior, D.B., editors, Slope instability: New York, John Wiley and Sons, p. 257-361.

Kellerhals, Rolf, and Bray, D.I., 1971, Sampling procedures for coarse fluvial sediments: American Society of Civil Engineers, Journal of the Hydraulics Division, v. 97, p. 1165-1180.

Kieffer, S.W., 1985, The 1983 hydraulic jump in Crystal RapidImplications for river-running and geomorphic evolution in the Grand Canyon: Journal of Geology, v. 93, p. 385-406.
Laenen, Antonious, Scott, K.M., Costa, J.E., and Orzol, L.L., 1987, Hydrologic hazards along Squaw Creek from a hypothetical failure of a glacial moraine impounding Carver Lake near Sisters, Oregon: U.S. Geological Survey Open-File Report 87-41, 48 p.

Laursen, E.M., Ince, Simon, and Pollack, Jack, 1976, On sediment transport through the Grand Canyon, in Proceedings of the Third Inter-Agency Sedimentation Conference, Denver, Colorado, p. 4-76 to $4-87$.

Leopold, L.B., 1969, The rapids and pools-Grand Canyon, in The Colorado River Region and John Wesley Powell: U.S. Geological Survey Professional Paper 669, p. 131-145.

McKee, E.D., 1969, Stratified rocks of the Grand Canyon, in The Colorado River Regions and John Wesley Powell: U.S. Geological Survey Professional Paper 669, p. 23-58.

1982, The Supai Group of Grand Canyon: U.S. Geological Survey Professional Paper 1173, 504 p.

Pacific Southwest Inter-Agency Committee, 1968, Factors affecting sediment yield and measures for the reduction of erosion and sediment yield: Pacific Southwest Inter-Agency Committee Report, $23 \mathrm{p}$.

Pierson, T C., 1980, Erosion and deposition by debris flows at Mt Thomas, North Canterbury, New Zealand: Earth Surface Processes, v. 5 , p. 227-247.

1981, Dominant particle support mechanisms in debris flows at Mt Thomas, New Zealand, and implications for flow mobility: Sedimentology, v. 28 , p. 49-60.

1985, Initiation and flow behavior of the 1980 Pine Creek and Muddy River lahars, Mount St.Helens, Washington: Geological Society of America Bulletin, v. 96, p. 1056-1069.

Pierson, T.C., and Scott, K.M., 1985, Downstream dilution of a laharTransition from debris flow to hyperconcentrated streamflow: Water Resources Research, v. 21, p. 1511-1524.

Piper, D.J.W., Farre, J.A., and Shor, A., 1985, Late Quaternary slumps and debris flows on the Scotian slope: Geological Society of America Bulletin, v. 96, p. 1508-1517.

Postma, George, 1986, Classification for sediment gravity-flow deposits based on flow conditions during sedimentation: Geology, v. 14, p. 291-294.

Potochnik, A.R., and Reynolds, S.J., 1986, Geology of side canyons of the Colorado, Grand Canyon National Park: Arizona Bureau of Geology and Mineral Technology Fieldnotes, v. 16, p. 1-8.

Rogers, J.D., and Pyles, M.R., 1979, Evidence of catastrophic erosional events in the Grand Canyon of the Colorado River, Arizona, in Proceedings of the 2nd Conference on Scientific Research in the National Parks, 26-30 November, San Francisco, California [reprint].

Schmidt, J.C., and Graf, J.B., 1988, Aggradation and degradation of alluvial sand deposits, 1965 to 1986, Colorado. River, Grand Canyon National Park, Arizona: U.S. Geological Survey Open-File Report 87-555, $120 \mathrm{p}$.

Scott, K.M., 1985, Lahars and lahar-runout flows in the Toutle-Cowlitz River system, Mount St. Helens, Washington-Origins, behavior, and sedimentology: U.S. Geological Survey Open-File Report 85-500, $202 \mathrm{p}$.

Smith, G.A., 1986, Coarse-grained nonmarine volcaniclastic sedimentTerminology and depositional process: Geological Society of America Bulletin, v. 97, p. 1-10.

Stevens, Larry, 1983, The Colorado River in Grand Canyon: Flagstaff, Arizona, Red Lake Books, 107 p.

Taylor, R.E., Donahue, D.J., Zabel, T.H., Damon, P.E., and Jull, A.J.T., 1984, Radiocarbon dating by particle accelerators-An archaeological perspective: American Chemical Society Advances in Chemistry Series, no. 205, Archaeological Chemistry, v. III, p. 333-356. 
TABLES 1-12 
[ $\mathrm{X}$ indicates that the attribute listed in the column heading was either observed or measured in the drainage.]

\begin{tabular}{|c|c|c|c|c|c|}
\hline Tributary name & $\begin{array}{l}\text { Colorado } \\
\text { River } \\
\text { mile }\end{array}$ & $\begin{array}{c}\text { Ancient } \\
\text { debris-flow } \\
\text { deposits }\end{array}$ & $\begin{array}{c}\text { Recent } \\
\text { debris-flow } \\
\text { evidence }\end{array}$ & $\begin{array}{l}\text { Strati- } \\
\text { graphy }\end{array}$ & $\begin{array}{l}\text { Events } \\
\text { analyzed }\end{array}$ \\
\hline 19-Mile Canyon & 19.0 & $\mathrm{x}$ & & & \\
\hline 24.5 Mile Canyon & 24.5 & $\mathrm{x}$ & $\mathrm{x}$ & $\mathrm{x}$ & \\
\hline Shinumo Wash & 29.2 & $\mathrm{x}$ & $\mathrm{x}$ & & \\
\hline Buck Farm Canyon & 41.0 & $\mathrm{x}$ & $\mathrm{x}$ & & \\
\hline Unnamed canyon & 43.3 & $\mathrm{x}$ & $\mathrm{X}$ & & \\
\hline Saddle Canyon & 47.0 & $\mathrm{x}$ & & & \\
\hline Nankoweap Creek & 52.2 & $\mathrm{x}$ & $\mathrm{x}$ & & \\
\hline Lava-Chuar Creek & 65.5 & $\mathrm{x}$ & $\mathrm{X}$ & $\mathrm{x}$ & $\mathrm{x}$ \\
\hline Palisades Creek & 65.7 & $\mathrm{x}$ & $\mathrm{x}$ & & \\
\hline Tanner Canyon & 68.5 & $\mathrm{x}$ & & & \\
\hline Cardenas Creek & 70.9 & $\mathrm{x}$ & $\mathrm{x}$ & & \\
\hline Unkar Creek & 72.7 & $\mathrm{x}$ & & & \\
\hline 75-Mile Canyon & 75.5 & $\mathrm{x}$ & & $\mathrm{X}$ & \\
\hline Red Canyon & 76.8 & $\mathrm{x}$ & $\mathrm{x}$ & & \\
\hline Clear Creek & 84.2 & $\mathrm{x}$ & $\mathrm{x}$ & & \\
\hline Bright Angel Creek & 87.9 & $\mathrm{x}$ & & & \\
\hline Monument Creek & 93.5 & $\mathrm{x}$ & $\mathrm{x}$ & $\mathrm{X}$ & $\mathrm{x}$ \\
\hline Crystal Creek & 98.2 & $\mathrm{x}$ & $\mathrm{x}$ & $\mathrm{X}$ & $\mathrm{X}$ \\
\hline Shinumo Creek & 108.6 & $\mathrm{x}$ & & & \\
\hline Elves Chasm & 116.5 & $\mathrm{X}$ & $\mathrm{X}$ & $\mathrm{x}$ & \\
\hline Blacktail Canyon & 120.2 & $\mathrm{x}$ & & & \\
\hline Forster Canyon & 122.8 & $\mathrm{x}$ & & & \\
\hline Fossil Canyon & 125.0 & $\mathrm{x}$ & $\mathrm{x}$ & & \\
\hline Unnamed canyon & 127.6 & $\mathrm{x}$ & $\mathrm{X}$ & & \\
\hline Deer Creek & 136.1 & $\mathrm{x}$ & & & \\
\hline Kanab Creek & 143.5 & $\mathrm{x}$ & & $\mathrm{x}$ & \\
\hline 0lo Canyon & 145.7 & $\mathrm{x}$ & & & \\
\hline Matkatimiba Creek & 148.0 & $\mathrm{x}$ & & & \\
\hline Havasu Creek & 156.9 & $\mathrm{x}$ & & $\mathrm{X}$ & \\
\hline National Canyon & 166.6 & $\mathrm{x}$ & $\mathrm{x}$ & & \\
\hline Fern Glen Canyon & 167.9 & $\mathrm{x}$ & $\mathrm{x}$ & & \\
\hline Prospect Canyon & 179.3 & $\mathrm{x}$ & & $\mathrm{X}$ & \\
\hline Parashant Wash & 198.5 & $\mathrm{x}$ & & $\mathrm{x}$ & \\
\hline Fa11 Canyon & 211.6 & $\mathrm{x}$ & $\mathrm{x}$ & & \\
\hline 220-Mile Canyon & 220.0 & $\mathrm{x}$ & & $\mathrm{X}$ & \\
\hline Diamond Creek & 225.8 & $\mathrm{X}$ & $\mathrm{x}$ & & \\
\hline
\end{tabular}

${ }^{1}$ River miles are measured from Lees Ferry (Stevens, 1983). 
TABLE 2.-Indirect-discharge calculation for the debris flow of 1966 on Lava-Chuar Creek, 0.2 mile upstream from the Colorado River

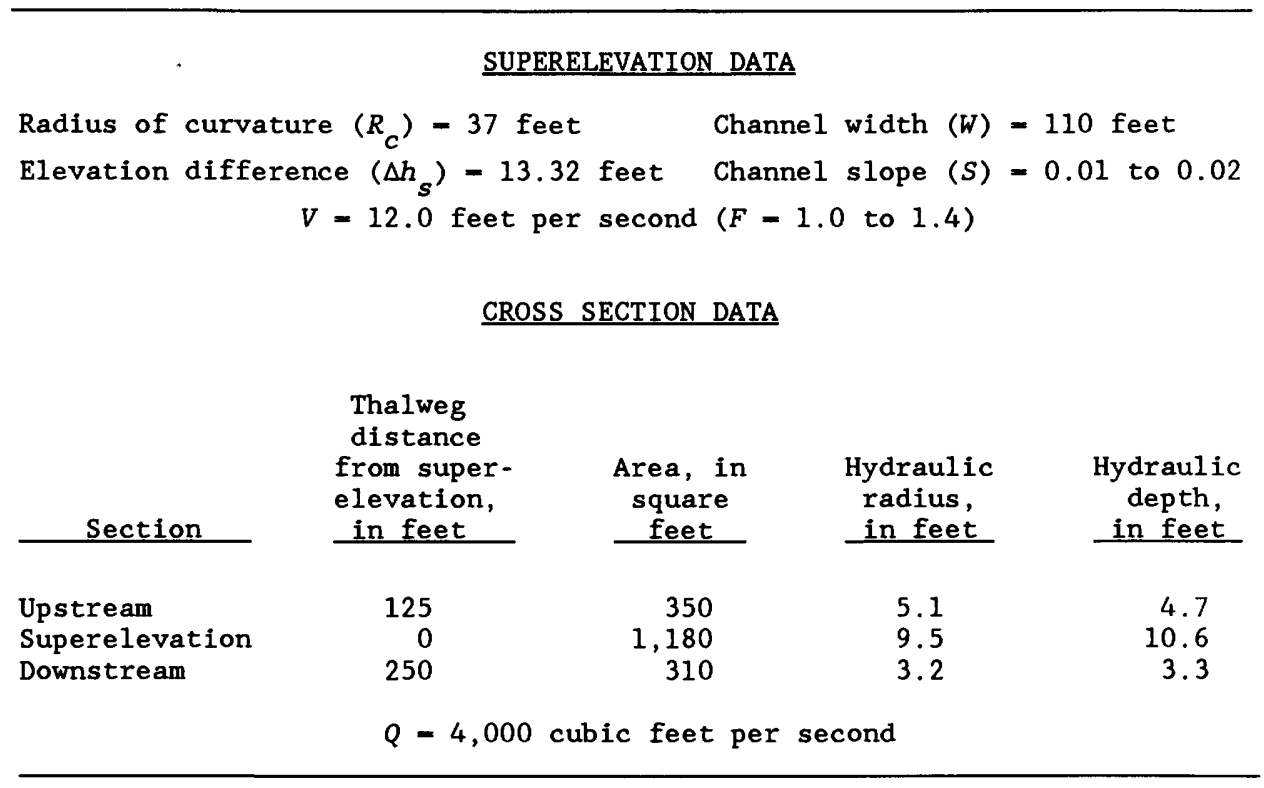

TABLE 3.-Indirect-discharge calculation for the debris flow of 1984 on Monument Creek at Tapeats Alcove, 1.5 miles upstream from the Colorado River

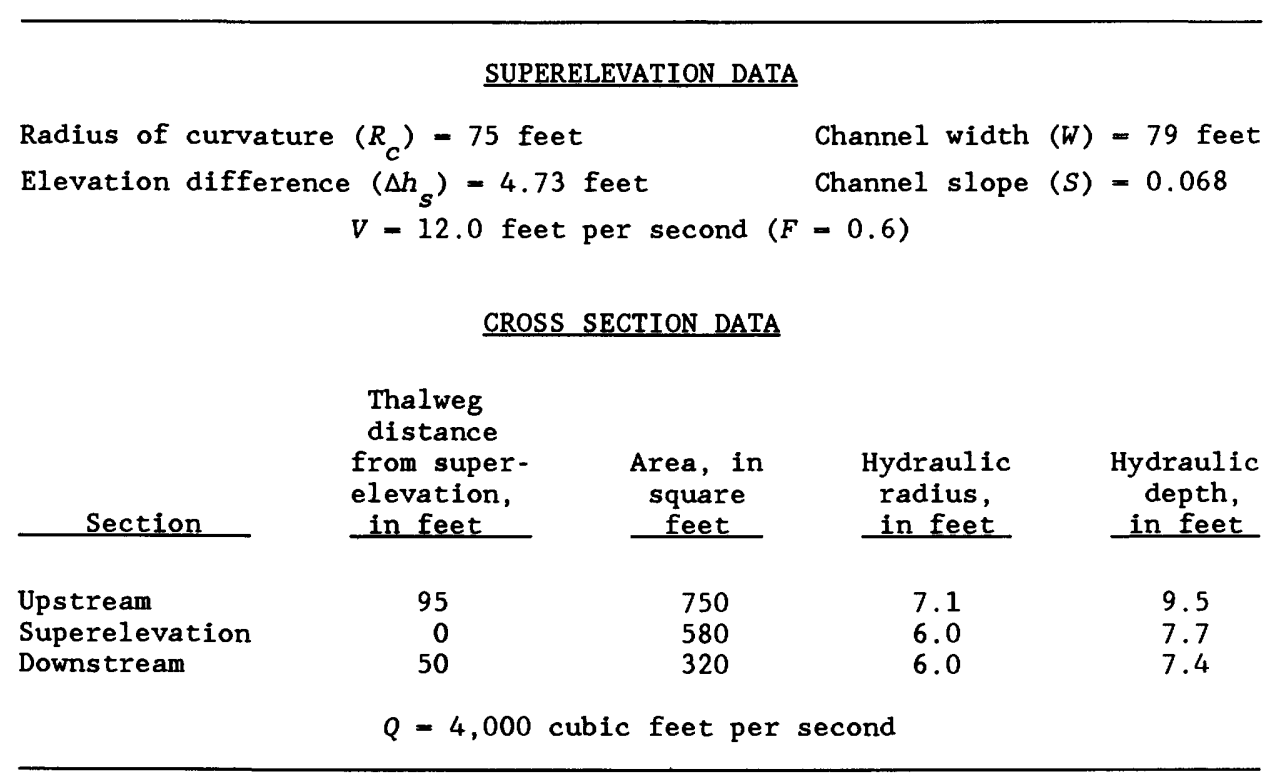


TABLE 4.-Indirect-discharge calculations for the debris flow of 1984 on Monument Creek at site B, 0.5 mile upstream from the Colorado River

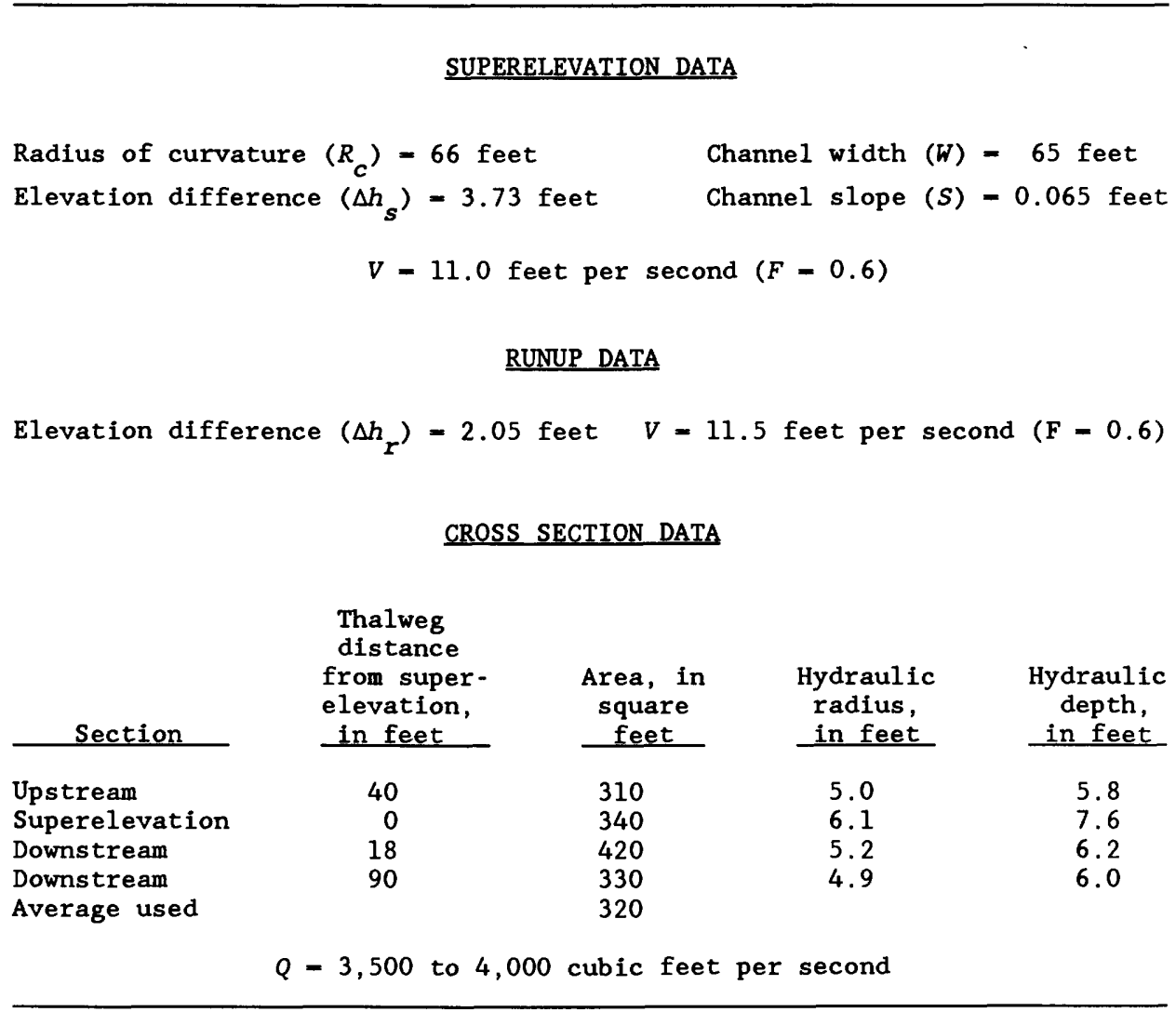

TABLE 5.-Indirect-discharge calculation for the debris flow of 1984 on Monument Creek at site C, 0.3 mile upstream from the Colorado River

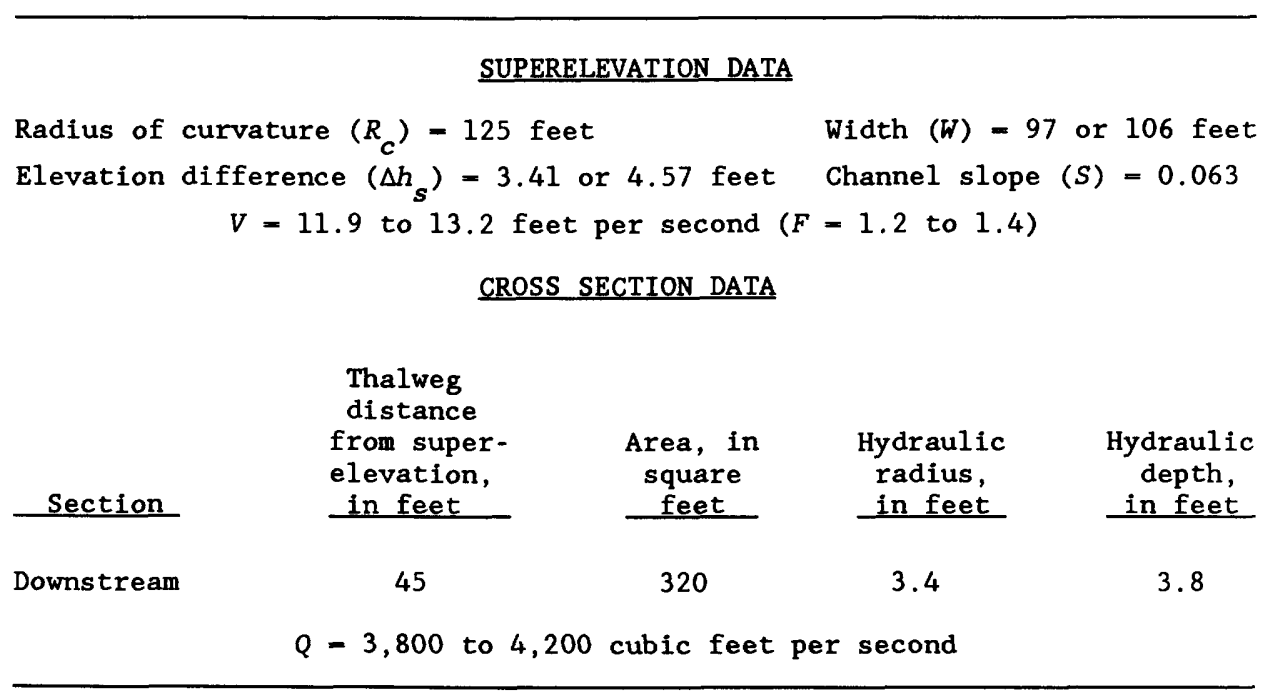


TABLE 6.-Four scenarios of deposition on the Monument Creek debris fan used to calculate volumes of sediment deposited during the debris flow of 1984

\section{SCENARIOS}

1. Assume that debris flow did not reach the Colorado River and that the debris fan present in 1986 is the maximum deposition (unrealistically low).

2. Assume that the debris flow covered the fan and half of the Colorado River bed to a depth of 3 feet.

3. Assume that the debris flow covered the entire bed of the Colorado River to a depth of 3 feet (most realistic).

4. Assume that the debris flow totally dammed the river to a depth of 11 feet (unrealistically high).

\section{FAN VOLUMES}

\begin{tabular}{|c|c|c|c|c|c|c|c|}
\hline Scenario & $\begin{array}{c}\text { Fan } \\
\text { volume, } \\
\text { in } \\
\text { cubic } \\
\text { feet }^{1} \\
\end{array}$ & $\begin{array}{c}\text { River } \\
\text { area, } \\
\text { in } \\
\text { square } \\
\text { feet } \\
\end{array}$ & $\begin{array}{l}\text { River } \\
\text { depth, } \\
\text { in } \\
\text { feet }\end{array}$ & $\begin{array}{c}\text { River } \\
\text { volume } \\
\text { in } \\
\text { cubic } \\
\text { feet }\end{array}$ & $\begin{array}{l}\text { Total } \\
\text { volume } \\
\text { in } \\
\text { cubic } \\
\text { feet } \\
\end{array}$ & $\begin{array}{c}\text { Sand } \\
\text { volume } \\
\text { in } \\
\text { cubic } \\
\text { feet }^{2} \\
\end{array}$ & $\begin{array}{l}\text { Duration } \\
\text { of peak } \\
\left(T_{p}\right) \text {, in } \\
\text { seconds } \\
\end{array}$ \\
\hline $\begin{array}{l}1 \\
2 \\
3 \\
4\end{array}$ & $\begin{array}{l}160,000 \\
160,000 \\
160,000 \\
160,000\end{array}$ & $\begin{array}{r}0 \\
26,000 \\
49,000 \\
49,000\end{array}$ & $\begin{array}{r}0 \\
3 \\
3 \\
11\end{array}$ & $\begin{array}{r}0 \\
80,000 \\
150,000 \\
270,000\end{array}$ & $\begin{array}{l}160,000 \\
240,000 \\
310,000 \\
430,000\end{array}$ & $\begin{array}{r}56,000 \\
84,000 \\
110,000 \\
150,000\end{array}$ & $\begin{array}{r}60 \\
90 \\
120 \\
160\end{array}$ \\
\hline
\end{tabular}

${ }^{1}$ Average fan depth is an estimated 5 feet over a 32,000 feet ${ }^{2}$ area.

2 The debris flow was approximately 35 percent sand.

${ }^{3} \mathrm{~A}$ total discharge of $3,800 \mathrm{ft}^{3} / \mathrm{s}$ and a sediment discharge of 2,700 $\mathrm{ft}^{3} / \mathrm{s}$ was used to estimate the duration of peak discharge. 
TABLE 7.-Indirect-discharge calculation for the debris flow of 1966 on Dragon Creek at site E, 5.0 miles upstream from the Colorado River

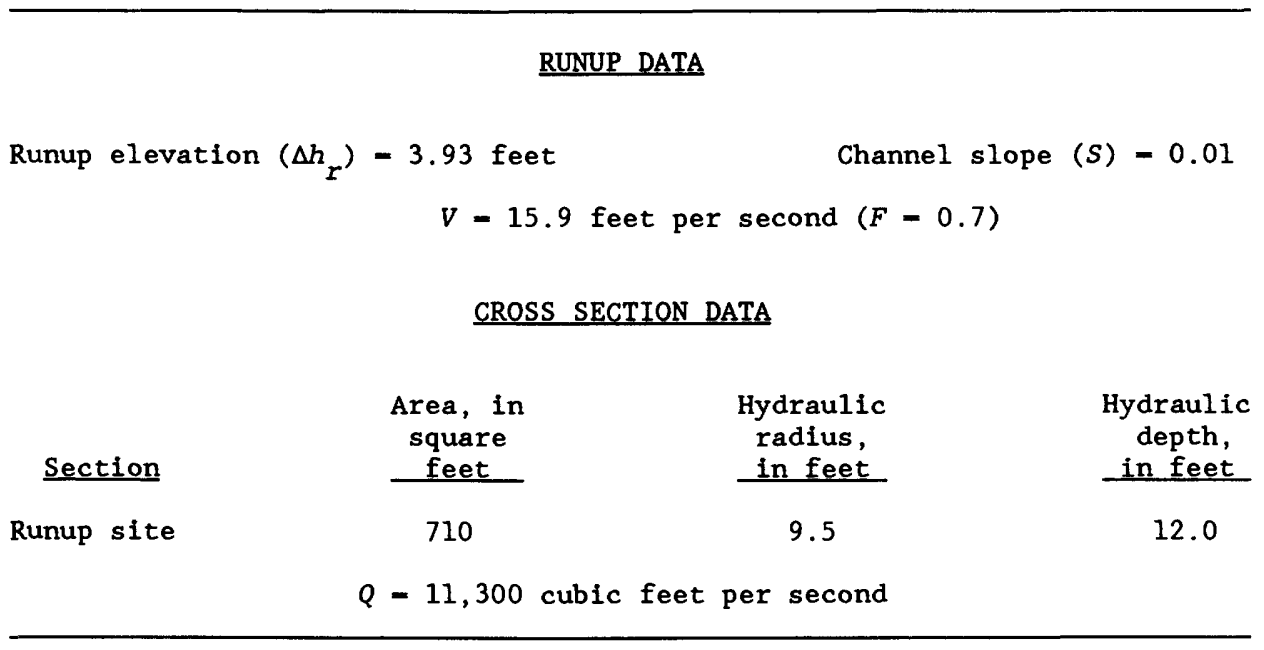

TABLE 8.-Indirect-discharge calculation for the debris flow of 1966 on Dragon Creek at site F, 4.8 miles upstream from the Colorado River

SUPERELEVATION DATA

Radius of curvature $\left(R_{c}\right)=75$ feet Channel width $(W)=175$ feet

Elevation difference $\left(\Delta h_{s}\right)=22.67$ feet Channel slope $(S)=0.06$

$V=17.7$ feet per second $(F=1.3$ to 2.7$)$

CROSS SECTION DATA

\begin{tabular}{|c|c|c|c|c|}
\hline Section & $\begin{array}{l}\text { Thalweg } \\
\text { distance } \\
\text { from super- } \\
\text { elevation, } \\
\text { in feet } \\
\end{array}$ & $\begin{array}{c}\text { Area, in } \\
\text { square } \\
\text { feet } \\
\end{array}$ & $\begin{array}{l}\text { Hydraulic } \\
\text { radius, } \\
\text { in feet } \\
\end{array}$ & $\begin{array}{c}\text { Hydraulic } \\
\text { depth, } \\
\text { in feet } \\
\end{array}$ \\
\hline $\begin{array}{l}\text { Upstream \#1 } \\
\text { Upstream \#2 } \\
\text { Superelevation } \\
\text { Downstream } \\
\text { Average }\end{array}$ & $\begin{array}{r}210 \\
90 \\
0 \\
80\end{array}$ & $\begin{array}{r}870 \\
670 \\
2,480 \\
840 \\
790\end{array}$ & $\begin{array}{r}7.0 \\
3.9 \\
12.5 \\
5.9\end{array}$ & $\begin{array}{r}7.4 \\
3.6 \\
14.2 \\
6.9\end{array}$ \\
\hline
\end{tabular}


TABLE 9.-Indirect-discharge calculations for the debris flow of 1966 on Crystal Creek at site G, 0.9 mile upstream from the Colorado River

\section{SUPERELEVATION DATA}

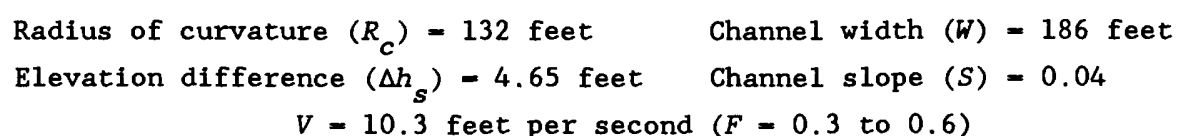

RUNUP DATA

Elevation \#1 $\left(\Delta h_{r}\right)=3.51$ feet $\quad V=15.0$ feet per second ( $F=0.6$ to 1.2 )

Elevation \#2 $\left(\Delta h_{r}\right)=3.68$ feet $\quad V=15.4$ feet per second $(F=0.6$ to 1.2 )

\section{CROSS SECTION DATA}

\begin{tabular}{|c|c|c|c|c|}
\hline Section & $\begin{array}{l}\text { Thalweg } \\
\text { distance } \\
\text { from super- } \\
\text { elevation, } \\
\text { in feet } \\
\end{array}$ & $\begin{array}{c}\text { Area, in } \\
\text { square } \\
\text { feet } \\
\end{array}$ & $\begin{array}{l}\text { Hydraulic } \\
\text { radius, } \\
\text { in feet } \\
\end{array}$ & $\begin{array}{c}\text { Hydraulic } \\
\text { depth, } \\
\text { in feet } \\
\end{array}$ \\
\hline $\begin{array}{l}\text { Upstream } \\
\text { Downstream \#1 } \\
\text { Downstream \#2 } \\
\text { Average }\end{array}$ & $\begin{array}{l}135 \\
185 \\
255\end{array}$ & $\begin{array}{r}940 \\
1,240 \\
890 \\
920\end{array}$ & $\begin{array}{r}5.6 \\
10.2 \\
9.7\end{array}$ & $\begin{array}{r}5.9 \\
11.5 \\
11.9\end{array}$ \\
\hline
\end{tabular}

TABLE 10.-Comparison of discharges calculated at all superelevation sites by the cross-sectional area at the highest superelevation marks and an average of the upstream and (or) downstream cross-sectional areas

\begin{tabular}{|c|c|c|c|c|c|}
\hline Location & $\begin{array}{l}\text { Mean } \\
\text { velo- } \\
\text { city, } \\
\text { in feet } \\
\text { per } \\
\text { second }\end{array}$ & $\begin{array}{c}\text { Area at } \\
\text { or near } \\
\text { superele- } \\
\text { vation, } \\
\text { in square } \\
\text { feet }\end{array}$ & $\begin{array}{l}\text { Dis- } \\
\text { charge, } \\
\text { in cubic } \\
\text { feet } \\
\text { per } \\
\text { second }\end{array}$ & $\begin{array}{l}\text { Average of } \\
\text { upstream } \\
\text { and down- } \\
\text { stream } \\
\text { area, in } \\
\text { square feet }\end{array}$ & $\begin{array}{c}\text { Dis- } \\
\text { charge, } \\
\text { in cubic } \\
\text { feet } \\
\text { per } \\
\text { second }\end{array}$ \\
\hline $\begin{array}{l}\text { Lava-Chuar Creek } \\
\text { at site F }\end{array}$ & 12.0 & 1,180 & 14,200 & 330 & 4,000 \\
\hline $\begin{array}{l}\text { Monument Creek } \\
\text { at Tapeats } \\
\text { Alcove }\end{array}$ & 12.0 & 580 & 7,000 & 320 & 3,800 \\
\hline $\begin{array}{l}\text { Monument Creek } \\
\text { site B }\end{array}$ & 11.0 & 420 & 4,600 & 320 & 3,500 \\
\hline $\begin{array}{l}\text { Monument Creek } \\
\text { site } C\end{array}$ & $11.9-13.2$ & $-\cdots$ & $\ldots$ & 320 & $3,800-4,200$ \\
\hline $\begin{array}{l}\text { Dragon Creek } \\
\text { site } \mathbf{F}\end{array}$ & 17.7 & 2,480 & 43,900 & 790 & 14,000 \\
\hline $\begin{array}{l}\text { Crystal Creek } \\
\text { site G }\end{array}$ & 10.3 & 1,240 & 12,800 & 920 & 9,500 \\
\hline
\end{tabular}


TABLE 11.-Historic flow events or channel changes in tributaries of the Colorado River in Grand Canyon National Park

[Determination of changes is somewhat subjective. A confidence rating of 1 indicates a change or event occurred; a rating of 2 indicates that though a change or event probably occurred, the evidence is not strong; a rating of 3 indicates little confidence in the reported change. An $\left({ }^{*}\right)$ asterisk indicates a major change or event.]

\begin{tabular}{|c|c|c|c|c|c|}
\hline \multicolumn{2}{|c|}{ River } & Tributary name & $\begin{array}{l}\text { Nature of } \\
\text { event or change }\end{array}$ & Year & $\begin{array}{c}\text { Confidence } \\
\text { rating }\end{array}$ \\
\hline 7.0 & $\mathbf{L}$ & Unnamed chute & Landslide & 1970 & 1 \\
\hline 7.8 & $\mathbf{R}$ & Badger Creek & Channel changes & $1973-84$ & 1 \\
\hline 11.2 & $\mathbf{R}$ & Soap Creek & Channel changes & $1935-65$ & 2 \\
\hline 11.2 & $\mathbf{R}$ & Soap Creek & Channel changes & $1973-84$ & 1 \\
\hline 11.8 & $\mathbf{L}$ & Salt Water Wash & Channel changes & $1935-65$ & 2 \\
\hline 11.8 & $\mathbf{L}$ & Salt Water Wash & Channel changes & $1973-84$ & 2 \\
\hline 16.8 & $\mathbf{R}$ & Rider Canyon & Channel changes & $1935-73$ & 2 \\
\hline 17.5 & $\mathbf{L}$ & 'Redneck Rapid' & Rockfall & $1978-79$ & 1 \\
\hline 26.8 & $\mathbf{R}$ & 'MNA Rapid' & Rockfall & 1975 & 1 \\
\hline 31.5 & $\mathbf{R}$ & South Canyon & Channel changes & $1965-73$ & 2 \\
\hline 35.6 & $\mathbf{L}$ & Unnamed channel & Fan changes & $1973-84$ & 1 \\
\hline 37.4 & $\mathbf{L}$ & Tatahatso Wash & Rockfall & 1977 & 1 \\
\hline 37.4 & $\mathbf{L}$ & Tatahatso Wash & Channel changes & $1973-84$ & 2 \\
\hline 41.0 & $\mathbf{R}$ & Buck Farm Wash & Debris flow & $1981-83$ & 1 \\
\hline 41.4 & $\mathbf{R}$ & Bert's Canyon & Channel changes & $1973-84$ & 2 \\
\hline 43.1 & $\mathbf{L}$ & 43 mile camp canyon & Debris flow & 1983 & 1 \\
\hline 43.7 & $\mathbf{R}$ & President Harding & *Rapid formed & $1911-23$ & 1 \\
\hline 43.7 & $\mathbf{L}$ & President Harding & Fan changes & $1973-84$ & 1 \\
\hline 44.1 & $\mathbf{L}$ & Fan below Harding & Fan changes & 1983 & 1 \\
\hline 44.5 & $\mathbf{L}$ & Fan below Harding & Fan changes & 1983 & 1 \\
\hline 44.8 & $\mathbf{L}$ & Fan below Harding & Fan changes & 1983 & 1 \\
\hline 52.0 & $\mathbf{R}$ & Nankoweap Creek & Channel shifted & $1935-65$ & 1 \\
\hline 52.0 & $\mathbf{R}$ & Nankoweap Creek & Channel shifted & 1966 & 1 \\
\hline 52.0 & $\mathbf{R}$ & Nankoweap Creek & Channel shifted & $1973-84$ & 1 \\
\hline 65.5 & $\mathbf{R}$ & Lava Creek & Debris flow & 1966 & 1 \\
\hline 65.5 & $\mathbf{R}$ & Lava Creek & Debris flow & $1973-84$ & 1 \\
\hline 65.5 & $\mathbf{L}$ & Palisades Creek & *Debris flow & $1965-73$ & 1 \\
\hline 65.5 & $\mathbf{L}$ & Palisades Creek & Channel changes & $1973-84$ & 2 \\
\hline 66.3 & $\mathbf{R}$ & Chute below Lava $\mathrm{Cr}$ & Fan changes & $1965-84$ & 1 \\
\hline 66.3 & $\mathbf{L}$ & Chute below Palisade & Channel changes & $1965-73$ & 2 \\
\hline 66.9 & $\mathbf{L}$ & Espejo Creek & Fan changes & $1973-84$ & 1 \\
\hline 67.2 & $\mathbf{L}$ & Comanche Creek & Fan changes & $1973-84$ & 1 \\
\hline 67.9 & $\mathbf{L}$ & Unnamed drainage & Fan changes & $1965-84$ & 1 \\
\hline 68.1 & $\mathbf{L}$ & Unnamed drainage & Fan changes & $1965-73$ & 2 \\
\hline 69.6 & $\mathbf{R}$ & Basalt Creek & *Flood & 1983 & 1 \\
\hline 70.0 & $\mathbf{R}$ & Unnamed drainage & Fan changes & $1973-85$ & 1 \\
\hline 70.2 & $\mathbf{R}$ & Unnamed drainage & Fan changes & $1965-84$ & 1 \\
\hline 70.3 & $\mathbf{R}$ & Unnamed drainage & Fan changes & $1965-84$ & 1 \\
\hline 70.4 & L & Unnamed drainage & Fan changes & $1973-84$ & 1 \\
\hline 70.5 & L & Unnamed drainage & Fan changes & $1973-84$ & 1 \\
\hline 70.8 & $\mathbf{L}$ & Unnamed drainage & Fan changes & $1973-84$ & 1 \\
\hline 70.9 & $\overline{\mathrm{R}}$ & Unnamed drainage & Fan changes & $1973-84$ & 2 \\
\hline 71.0 & $\mathbf{L}$ & Cardenas Creek & Channel changes & 1984 & 1 \\
\hline 71.2 & $\mathbf{R}$ & Unnamed drainage & Fan changes & $1965-84$ & 1 \\
\hline 71.3 & $\mathbf{R}$ & Unnamed drainage & Debris flow & 1983 & 1 \\
\hline 71.8 & $\mathbf{R}$ & Unnamed drainage & Fan changes & $1973-84$ & 1 \\
\hline 72.0 & $\mathbf{R}$ & Unnamed drainage & Rockfall, flood & 1983 & 1 \\
\hline 72.5 & $\mathbf{R}$ & Unkar Creek & Channel changes & 1966 & 1 \\
\hline 72.5 & $\mathbf{R}$ & Unkar Creek & Channel changes & $1973-84$ & 1 \\
\hline 73.3 & L & 6-8 small gullies & Channel changes & $1973-84$ & 1 \\
\hline 73.5 & L & Unnamed drainage & Fan changes & $1965-84$ & 2 \\
\hline 73.7 & $\mathbf{R}$ & Unnamed chute & Fan changes & $1973-84$ & 1 \\
\hline 73.8 & $\mathbf{R}$ & Unnamed chute & Fan changes & $1973-84$ & 1 \\
\hline 74.4 & $\mathbf{R}$ & Unnamed chute & Fan changes & $1965-84$ & 2 \\
\hline 74.9 & $\mathbf{L}$ & Escalante Creek & Fan changes & $1973-84$ & 1 \\
\hline 76.8 & L & Red Canyon & Channel changes & $1973-84$ & 2 \\
\hline 87.8 & $\mathbf{R}$ & Bright Angel Creek & Large flood & 1936 & 1 \\
\hline 87.8 & $\mathbf{R}$ & Bright Angel Creek & *Channel changes & 1966 & 1 \\
\hline 87.8 & $\mathbf{R}$ & Bright Ange1 Creek & Channel changes & $1973-84$ & 1 \\
\hline 89.0 & L & Pipe Creek & Channel changes & $1973-84$ & 2 \\
\hline 91.5 & $\mathbf{R}$ & Trinity Creek & Flood or debris flow & 1985 & 1 \\
\hline 92.2 & $\mathrm{~L}$ & Unnamed chute & Channel changes & $1973-84$ & 2 \\
\hline 92.8 & $\mathbf{L}$ & Salt Creek & Channel changes & $1973-84$ & 2 \\
\hline
\end{tabular}


TABLE 11.-Historic flow events or channel changes in tributaries of the Colorado River in Grand Canyon National Park-Continued

\begin{tabular}{|c|c|c|c|c|c|}
\hline \multicolumn{2}{|c|}{$\begin{array}{l}\text { River } \\
\text { mile side }\end{array}$} & Tributary name & $\begin{array}{l}\text { Nature of } \\
\text { event or change }\end{array}$ & Year & \multirow[t]{2}{*}{$\begin{array}{l}\text { Confidence } \\
\text { rating }\end{array}$} \\
\hline 93.5 & L & Monument Creek & *Debris flow & 1984 & \\
\hline 96.7 & $\mathrm{~L}$ & Boucher Creek & Channel changes & $1973-84$ & 2 \\
\hline 96.9 & $\mathbf{L}$ & Chute below Boucher & Channel changes & $1973-84$ & 3 \\
\hline 98.2 & $\mathbf{R}$ & Crystal Creek & *Debris flow & 1966 & 1 \\
\hline 98.2 & $\mathbf{R}$ & Crystal Creek & Channe1 changes & $1973-84$ & 1 \\
\hline 100.6 & $\mathrm{~L}$ & Agate Creek & Channel changes & $1973-84$ & 1 \\
\hline 102.0 & $\mathbf{L}$ & Turquoise Creek & Channel changes & $1973-84$ & 2 \\
\hline 108.6 & $\mathbf{R}$ & Shinumo Creek & Channel changes & $1973-84$ & 2 \\
\hline 115.5 & L & Unnamed canyon & Channe1 changes & 1985 & 1 \\
\hline 116.5 & L & Elves Chasm & *Debris flow & 1985 & 1 \\
\hline 119.0 & $\mathbf{R}$ & 119-Mile Creek & Channel changes & $1973-84$ & 1 \\
\hline 121.7 & L & Unnamed chute & Channel changes & $1973-84$ & 1 \\
\hline 122.7 & $\mathrm{~L}$ & Forster Creek & *Channel changes & $1973-84$ & 1 \\
\hline 122.2 & L & Unnamed chute & Channel changes & $1973-84$ & 1 \\
\hline 128.4 & $\mathbf{R}$ & 128-Mile Creek & Channel changes & $1973-84$ & 1 \\
\hline 129.0 & L & Spector Chasm & Channe1 changes & $1973-84$ & 2 \\
\hline 132.0 & $\mathbf{R}$ & Stone Creek & Channel changes & $1973-84$ & 2 \\
\hline 132.0 & L & Unnamed chute & *New fan & $1872-1968$ & 1 \\
\hline 133.8 & $\mathbf{R}$ & Tapeats Creek & *Debris flow & 1961 & 1 \\
\hline 133.8 & $\mathbf{R}$ & Tapeats Creek & Flood & 1975 & 1 \\
\hline 133.8 & $\mathbf{R}$ & Tapeats Creek & Flood & 1984 & 1 \\
\hline 136.2 & $\mathbf{R}$ & Deer Creek & Debris flow & 1985 & 1 \\
\hline 137.2 & $\mathbf{R}$ & Unnamed chute & Debris flow & $1973-84$ & 1 \\
\hline 143.5 & $\mathbf{R}$ & Kanab Creek & *Large flood & 1883 & 1 \\
\hline 143.5 & $\mathbf{R}$ & Kanab Creek & *Large flood & 1909 & 1 \\
\hline 143.5 & $\mathbf{R}$ & Kanab Creek & Channe1 changes & $1973-84$ & 1 \\
\hline 156.8 & $\mathrm{~L}$ & Havasu Creek & *Large flood & 1911 & 1 \\
\hline 166.5 & $\mathrm{~L}$ & National Canyon & Channe 1 changes & 1984 & 1 \\
\hline 168.0 & $\mathbf{R}$ & Fern Glen Canyon & Channel changes & $1973-84$ & 2 \\
\hline 174.2 & $\mathbf{R}$ & Cove Canyon & Channel changes & $1973-84$ & 1 \\
\hline 176.4 & $\mathbf{R}$ & Saddle Horse Canyon & Channel changes & $1973-84$ & 1 \\
\hline 178.1 & $\mathbf{R}$ & Unnamed chute & Debris flow & $1973-84$ & 1 \\
\hline 181.3 & $\mathbf{R}$ & Unnamed chute & Debris flow & 1973 & 1 \\
\hline 202.2 & $\mathbf{R}$ & Unnamed canyon & Debris flow & $1973-84$ & 2 \\
\hline 202.3 & $\mathbf{R}$ & Unnamed canyon & Debris flow & $1973-84$ & 1 \\
\hline 203.8 & $\mathbf{R}$ & Unnamed canyon & Debris flow & $1973-84$ & 3 \\
\hline 204.1 & $\mathrm{~L}$ & Unnamed canyon & Channel changes & $1973-84$ & 2 \\
\hline 205.2 & $\mathrm{~L}$ & 205-Mile Creek & *Channe1 changes & 1983 & 1 \\
\hline 207.9 & $\mathrm{~L}$ & Unnamed canyon & Channel changes & $1973-84$ & 3 \\
\hline 209.0 & $\mathbf{R}$ & Unnamed chute & Rockfall & $1978-79$ & 1 \\
\hline 211.5 & $\mathbf{R}$ & Fa11 Canyon & Channel changes & $1973-84$ & 1 \\
\hline 220.0 & $\mathbf{R}$ & 220-Mile Creek & Channel changes & 1984 & 1 \\
\hline 225.8 & $\mathrm{~L}$ & Diamond Creek & *Debris flow & 1984 & 1 \\
\hline
\end{tabular}


TABLE 12.-Relation between difficulty rating for rapids and drainage area of the contributing tributaries for 67 rapids on the Colorado River

[Rapid rating is a subjective scale from 1 (least severe) to 10 (most severe) based on navigational difficulty for oar-powered boats (Stevens, 1983)]

\begin{tabular}{|c|c|c|c|c|}
\hline Rapid name & $\begin{array}{l}\text { River } \\
\text { mile }\end{array}$ & $\begin{array}{l}\text { Contributing } \\
\text { area of } \\
\text { drainages, } \\
\text { in square } \\
\text { miles }\end{array}$ & $\begin{array}{l}10,000 \\
\text { cubic feet } \\
\text { per second } \\
\text { rating }\end{array}$ & $\begin{array}{c}1921 \\
\text { Water-surface } \\
\text { fall, in feet }\end{array}$ \\
\hline Paria Riffle & 0.9 & $1,410.0$ & 1 & 2 \\
\hline Badger & 7.9 & 46.6 & 6 & 12 \\
\hline Soap Creek & 11.2 & 35.3 & 5 & 17 \\
\hline House Rock & 16.9 & 308.6 & 7 & 9 \\
\hline North Canyon & 20.5 & 154.1 & 5 & 12 \\
\hline 21 Mile & 21.1 & 0.3 & 5 & 5 \\
\hline Indian Dick & 23.2 & 0.1 & 5 & 6 \\
\hline $24.5 \mathrm{Mile}$ & 24.5 & 9.9 & 5 & 9 \\
\hline 25 Mile & 24.8 & 0.4 & 5 & 7 \\
\hline Cave Springs & 25.2 & 0.7 & 5 & 6 \\
\hline Tiger Wash & 26.7 & 19.8 & 4 & 7 \\
\hline 29 Mile & 29.2 & 60.8 & 2 & 6 \\
\hline Saddle Canyon & 47.0 & 11.3 & 1 & 1 \\
\hline Nankoweap & 52.2 & 32.6 & 3 & 25 \\
\hline Kwagunt & 56.0 & 15.2 & 6 & 19 \\
\hline Little Colorado & 61.5 & $26,955.0$ & 1 & 8 \\
\hline Lava Creek & 65.5 & 22.9 & 4 & 8 \\
\hline Basalt & 69.2 & 5.3 & 3 & 2 \\
\hline Unkar & 72.6 & 14.5 & 6 & $2 \overline{1}$ \\
\hline Nevills & 75.5 & 4.6 & 6 & 15 \\
\hline Nance & 76.8 & 4.1 & 9 & 26 \\
\hline Sockdolager & 78.7 & 9.0 & 9 & 19 \\
\hline Grapevine & 81.6 & 14.6 & 8 & 17 \\
\hline 83 Mile & 83.5 & 1.7 & 4 & 7 \\
\hline Clear Creek & 84.1 & 35.7 & 1 & 2 \\
\hline Zoroaster & 84.5 & 1.5 & 6 & 7 \\
\hline 85 Mile & 85.0 & 0.1 & 3 & 6 \\
\hline Bright Ange1 & 87.9 & 101.0 & 4 & 8 \\
\hline Pipe Springs & 88.9 & 6.6 & 4 & 14 \\
\hline Horn Creek & 90.1 & 1.6 & 8 & 9 \\
\hline Salt Creek & 92.6 & 1.2 & 4 & 3 \\
\hline Granite & 93.5 & 3.3 & 9 & 17 \\
\hline 94 Mile Creek & 94.3 & 3.7 & 1 & 2 \\
\hline Hermit & 95.0 & 12.6 & 9 & 15 \\
\hline Boucher & 96.8 & 6.4 & 4 & 13 \\
\hline Crystal & 98.2 & 47.9 & 10 & 17 \\
\hline Tuna Creek & 99.2 & 23.3 & 6 & 10 \\
\hline Sapphire & 101.3 & 3.7 & 7 & 7 \\
\hline Turquoise & 102.0 & 5.7 & 4 & 2 \\
\hline 104 Mile & 103.9 & 1.7 & 6 & 3 \\
\hline Ruby & 104.8 & 6.6 & 6 & 8 \\
\hline Serpentine & 105.9 & 1.5 & 7 & 10 \\
\hline Bass & 107.5 & 5.5 & 4 & 4 \\
\hline Shinumo Creek & 108.5 & 85.5 & 4 & 8 \\
\hline Wal tenberg & 112.2 & 6.3 & 7 & 14 \\
\hline 112.5 Mile & 112.5 & 0.9 & 2 & 4 \\
\hline Rancid Tuna & 113.0 & 0.5 & 6 & 4 \\
\hline Blacktail & 120.1 & 9.3 & 3 & 7 \\
\hline 122 Mile & 121.8 & 3.1 & 5 & 4 \\
\hline Forster & 122.8 & 3.9 & 6 & 7 \\
\hline Fossil & 125.0 & 13.2 & 6 & 15 \\
\hline 128 Mile & 128.4 & 3.0 & 5 & 8 \\
\hline Specter & 129.0 & 3.1 & 6 & 5 \\
\hline Bedrock & 130.5 & 8.2 & 8 & 7 \\
\hline Deubendorf & 131.8 & 7.3 & 8 & 15 \\
\hline Tapeats & 133.8 & 82.9 & 6 & 7 \\
\hline 134 Mile & 134.3 & 2.2 & 3 & 7 \\
\hline 135 Mile & 134.9 & 1.8 & 5 & 2 \\
\hline Doris & 137.7 & 0.3 & 6 & 2 \\
\hline Fishtail & 139.0 & 7.7 & 6 & 10 \\
\hline Kanab Creek & 143.5 & $2,290.0$ & 3 & 18 \\
\hline
\end{tabular}


TABLE 12.-Relation between difficulty rating for rapids and drainage area of the contributing tributaries for 67 rapids on the Colorado River-Continued

\begin{tabular}{llccc}
\hline Rapid name & $\begin{array}{c}\text { Contributing } \\
\text { area of } \\
\text { drainages } \\
\text { in square } \\
\text { miles }\end{array}$ & $\begin{array}{c}10,000 \\
\text { cubic feet } \\
\text { per second } \\
\text { rating }\end{array}$ & $\begin{array}{c}1921 \\
\text { Water-surface } \\
\text { fall, in feet }\end{array}$ \\
\hline Upset & 149.8 & 30.9 & 8 & 15 \\
Lava Falls & 179.3 & 96.9 & 10 & 10 \\
205 Mile & 205.5 & 10.6 & 7 & 9 \\
209 Mile & 208.8 & 88.3 & 7 & 5 \\
L'il Bastard & 212.1 & 0.2 & 3 & 13 \\
217 Mile & 217.3 & 9.2 & 7 & \\
\hline
\end{tabular}




\section{SELECTED SERIES OF U.S. GEOLOGICAL SURVEY PUBLICATIONS}

\section{Periodicals}

Earthquakes \& Volcanoes (issued bimonthly).

Preliminary Determination of Epicenters (issued monthly).

\section{Technical Books and Reports}

Professional Papers are mainly comprehensive scientific reports of wide and lasting interest and importance to professional scientists and engineers. Included are reports on the results of resource studies and of topographic, hydrologic, and geologic investigations. They also include collections of related papers addressing different aspects of a single scientific topic.

Bulletins contain significant data and interpretations that are of lasting scientific interest but are generally more limited in scope or geographic coverage than Professional Papers. They include the results of resource studies and of geologic and topographic investigations; as well as collections of short papers related to a specific topic.

Water-Supply Papers are comprehensive reports that present significant interpretive results of hydrologic investigations of wide interest to professional geologists, hydrologists, and engineers. The series covers investigations in all phases of hydrology, including hydrogeology, availability of water, quality of water, and use of water.

Circulars present administrative information or important scientific information of wide popular interest in a format designed for distribution at no cost to the public. Information is usually of short-term interest.

Water-Resources Investigations Reports are papers of an interpretive nature made available to the public outside the formal USGS publications series. Copies are reproduced on request unlike formal USGS publications, and they are also available for public inspection at depositories indicated in USGS catalogs.

Open-File Reports include unpublished manuscript reports, maps, and other material that are made available for public consultation at depositories. They are a nonpermanent form of publication that may be cited in other publications as sources of information.

\section{Maps}

Geologic Quadrangle Maps are multicolor geologic maps on topographic bases in 71/2-or 15-minute quadrangle formats (scales mainly $1: 24,000$ or $1: 62,500$ ) showing bedrock, surficial, or engineering geology. Maps generally include brief texts; some maps include structure and columnar sections only.

Geophysical Investigations Maps are on topographic or planimetric bases at various scales; they show results of surveys using geophysical techniques, such as gravity, magnetic, seismic, or radioactivity, which reflect subsurface structures that are of economic or geologic signific ance. Many maps include correlations with the geology.

Miscellaneous Investigations Series Maps are on planimetric or topographic bases of regular and irregular areas at various scales; they present a wide variety of format and subject matter. The series also includes 7 1/2-minute quadrangle photogeologic maps on planimetric bases which show geology as interpreted from aerial photographs. Series also includes maps of Mars and the Moon.
Coal Investigations Maps are geologic maps on topographic or planimetric bases at various scales showing bedrock or surficial geology, stratigraphy, and structural relations in certain coal-resource areas.

Oil and Gas Investigations Charts show stratigraphic information for certain oil and gas fields and other areas having petroleum potential.

Miscellaneous Field Studies Maps are multicolor or black-andwhite maps on topographic or planimetric bases on quadrangle or irregular areas at various scales. Pre-1971 maps show bedrock geology in relation to specific mining or mineral-deposit problems; post-1971 maps are primarily black-and-white maps on various subjects such as environmental studies or wildemess mineral investigations.

Hydrologic Investigations Atlases are multicolored or black-andwhite maps on topographic or planimetric bases presenting a wide range of geohydrologic data of both regular and irregular areas; principal scale is $1: 24,000$ and regional studies are at $1: 250,000$ scale or smaller.

\section{Catalogs}

Permanent catalogs, as well as some others, giving comprehensive listings of U.S. Geological Survey publications are available under the conditions indicated below from the U.S. Geological Survey, Books and Open-File Reports Section, Federal Center, Box 25425, Denver, CO 80225. (See latest Price and Availability List.)

"Publications of the Geological Survey, 1879-1961" may be purchased by mail and over the counter in paperback book form and as a set of microfiche.

"Publications of the Geological Survey, 1962- 1970" may be purchased by mail and over the counter in paperback book form and as a set of microfiche.

"Publications of the U.S. Geological Survey, 1971-1981" may be purchased by mail and over the counter in paperback book form (two volumes, publications listing and index) and as a set of microfiche.

Supplements for $1982,1983,1984,1985,1986$, and for subsequent years since the last permanent catalog may be purchased by mail and over the counter in paperback book form.

State catalogs, "List of U.S. Geological Survey Geologic and Water-Supply Reports and Maps For (State)," may be purchased by mail and over the counter in paperback booklet form only.

"Price and Availability List of U.S. Geological Survey Publications," issued annually, is available free of charge in paperback booklet form only.

Selected copies of a monthly catalog "New Publications of the U.S. Geological Survey" available free of charge by mail or may be obtained over the counter in paperback booklet form only. Those wishing a free subscription to the monthly catalog "New Publications of the U.S. Geological Survey" should write to the U.S. Geological Survey, 582 National Center, Reston, VA 22092.

Note.--Prices of Government publications listed in older catalogs, announcements, and publications may be incorrect. Therefore, the prices charged may differ from the prices in catalogs, announcements, and publications. 